\title{
Servidor de Processamento \\ Paralelo - Análise e \\ Extensão dos Protocolos de Comunicação
}

Ana Luísa Pena de Andrade

Dissertação apresentada ao Instituto de Ciências Matemáticas de São Carlos - USP, como parte dos requisitos para obtenção do título de Mestre na Área de Ciências de Computação e Matemática Computacional.

Orientador:

Prof. Dr. Marcos José Santana.

Área de Concentração:

Sistemas Distribuídos e Programação Concorrente.

São Carlos

Novembro - 1994 
Ao Carlos e à Dulce, não só por este trabalho, mas principalmente por uma vida de dedicação. 


\section{Agradecimentos}

À Deus, por todas as oportunidades que tive no decorrer da minha vida.

Ao meu orientador e amigo, Marcos, por tudo: desde o apoio inicial, nas questões técnicas, até o apoio pessoal e amigo de sempre.

Ao Nivaldi, companheiro e amigo nas horas certas e incertas, um agradecimento especial por estar sempre pronto para qualquer tipo de ajuda solicitada.

À Regina pelos conselhos e dicas no decorrer desses anos, e também por eu ter praticamente sido incluída como mais um membro da família.

Ao Onofre pela oportunidade de trabalhar neste projeto (desde a iniciação cientifica) e pelo apoio para o término deste.

Aos meus irmãos e cunhados pela presença constante na minha vida, seja emocional ou financeiramente.

Aos técnicos do LaSD, Cabral e Eduardo; e ao pessoal do LDCC: Sônia, Elien, Luciano, Carmem e Ângelo, pela amizade e prestatividade de sempre.

Às meninas da biblioteca: Gi, Maria, Rose, Sandra, Silvana e Giselda; às meninas da secretaria: Ângela, Luiza e Sueli; ao pessoal da seção de alunos: Zé Ângelo, Paulinho e Sandra; ao Jacques; ao Antônio e Waldir, ao setor administrativo em geral, por estarem sempre tão prontos a resolver qualquer problema.

À Beth e Laura, pelo convivio durante o mestrado, pela amizade e por tantos "quebra-galhos".

Às meninas da república Wam-Wam e agregadas: Silvana, Tata, Silvia, Silvinha, Dri, Juliana, Fabiana, Lucila, por 
terem sido, por tanto tempo, o meu porto seguro em meio a tantas tempestades, e principalmente por continuarem a ser. Em especial à Silvia pelo auxílio estatístico. Obrigada!

Aos companheiros e amigos de mestrado: Titi, Cybelle, Pastel, Fritz, Boca, Regina, Renata, Roberta, Tchelo, Marquinhos, Hasegawa, Walter, Alneu, Josmar, Claudinha, Stein, Miudinho, ..., obrigada pela amizade nas mais diferentes situações! Ao Orlando, não só por ter se mostrado sempre tão amigo, mas também pelas ajudas na implementação. Ao Daniel, pelo apoio e incentivo de sempre, e por ser tão especial!

À Capes, pelo apoio financeiro parcial.

Ao pessoal do CTI, Centro Tecnológico para Informática, por compreenderem minha constante ausência nesse início de projeto.

A todas as pessoas aqui relacionadas e às que por um motivo ou outro não estão, agradeço a parcela de vida que elas deixaram em mim, cada uma de seu jeito, mas todas contribuindo para que a minha passagem por São Carlos seja inesquecível. Obrigada! 


\section{Índice}

Lista das Figuras iv

Indice das Tabelas $\quad v$

Índice dos Gráficos $\quad$ v

Glossário vi

Resumo $\quad$ ix

Abstract $\quad$ x

$\begin{array}{ll}1 \text { - Introdução } & 01\end{array}$

2 - Sistemas Distribuídos 05

2.1 Sistemas Centralizados $\quad 05$

2.2 Caracterização de Sistemas Distribuidos 07

2.3 Vantagens e Desvantagens (SD X SC) 08

2.4 Modelos para Projeto de Sistemas Distribuídos $\quad 10$

2.4.1 Pontos Relevantes ao Projeto 10

2.4.2 Modelos 10

2.5 Exemplos de Sistemas Distribuídos $\quad 12$

$\begin{array}{ll}2.6 \text { Considerações Finais } & 16\end{array}$

3 - Protocolos de Comunicação 17

$\begin{array}{ll}3.1 \text { O Modelo de Referência OSI } & 17\end{array}$

3.2 Protocolos TCP/IP 20

$\begin{array}{ll}3.3 \text { O Modelo Cliente/Servidor } & 22\end{array}$

3.4 Tecnologias de Redes Locais $\quad 23$

3.4.1 Padrão IEEE 802.3 e ETHERNET 24

3.4.2 Padrão IEEE 802.4: Token Bus 26

3.4.3 Padrão IEEE 802.5: Token Ring 27

3.4.4 Cambridge Ring 29

3.4.5 Cambridge Fast Ring $\quad 30$

3.4.6 FDDI (Fiber Distributed Data Interface) 30

$\begin{array}{ll}3.5 \text { Considerações Finais } & 30\end{array}$

4 - Troca de Mensagens $\quad 32$

4.1 Mecanismos para Troca de Mensagens $\quad 33$

$\begin{array}{ll}\text { 4.1.1 Rendez-vous } & 34\end{array}$

4.1.2 Rendez-vous Estendido $\quad 35$ 
4.2 Chamada a Procedimentos Remotos (RPC) 36

4.2.1 Aspectos de Projeto 37

4.2.2 O Mecanismo RPC 38

4.2.3 Semântica de Chamada 39

4.2.4 Representação de Dados $\quad 41$

4.2.5 Stubs e Interfaces $\quad 42$

4.3 Protocolos - Considerações Gerais 43

4.4 RPC - Considerações Gerais 43

4.5 Desempenho em RPCs 44

4.6 Considerações Finais $\quad 48$

5 - Revisão/Ampliação da Implementação Original do SPP 49

$\begin{array}{ll}5.1 \text { Organização do SPP } & 50\end{array}$

5.1.1 Hardware 50

5.1.2 Software 51

5.2 Projeto e Implementação do Software Original 53

5.2.1 Descrição dos Protocolos, Pacotes e

5.2.2 Estações de Trabalho $\quad 56$

5.2.3 Processador de Entrada $\quad 57$

5.3 Instalação do Sistema de Desenvolvimento TDS 58

5.3.1 Organização do Sistema de Desenvolvimento TDS 58

5.4 Decisões de Projeto 60

5.5 Projeto Lógico 61

5.6 Considerações Finais 65

6 - Utilização do Protocolo TCP/IP no Ambiente SPP 67

6.1 Disponibilidade/Flexibidade da Utilização do

SPP em função de um protocolo mais difundido $\quad 67$

6.2 O Programa net.exe 68

6.2.1 Arquivos de Configuração do Programa net 69

6.3 Projeto Lógico $\quad 72$

6.3.1 Dificuldades Encontradas 73

6.3.2 Alterações Efetuadas no Programa net 74

6.3.3 Utilização dos Transputers $\quad 76$

6.4 Considerações Finais $\quad 78$

7 - Análise dos Resultados $\quad 79$

7.1 Técnica Utilizada para o Teste 79

7.2 Testes Realizados - SPP $\quad 81$

7.2.1 Primeiro Teste Realizado $\quad 81$ 
7.3 Testes Realizados - Implementação TCP/IP 85

7.4 Considerações Finais $\quad 86$

$\begin{array}{ll}8 \text { - Conclusão } & 87\end{array}$

$\begin{array}{ll}\text { 8.1 Dificuldades Encontradas } & 87\end{array}$

8.2 Contribuições Deste Trabalho $\quad 88$

8.3 Trabalhos Futuros $\quad 88$

8.4 Comentários Finais $\quad 89$

$\begin{array}{ll}\text { Referências Bibliográficas } & 90\end{array}$

$\begin{array}{ll}\text { Apêndice A } & 94\end{array}$ 


\section{Lista das Figuras}

1.1 Rede Local com Segmentos Interligados por Pontes

02

2.1 Representação de um Computador como uma Máquina Virtual 06

2.2 Exemplo de um Pequeno Sistema Distribuido 07

2.3 Modelo Estação de Trabalho-Servidor 11

2.4 Modelo Banco de Processadores 11

2.5 Modelo Integrado 12

2.6 Sistema Trice $\quad 13$

2.7 A Arquitetura do Sistema Amoeba 14

3.1 O Modelo de Referência ISO/OSI 18

3.2 Comunicação entre os Processos de Aplicações nos Hospedeiros A e B através de dois nós da Rede $\quad 19$

3.3 Estrutura TCP/IP 20

3.4 Sequência de Comunicação Cliente-Servidor 23

3.5 Familia de Padrões para Redes Locais 24

3.6 Configuração Usual de uma Ethernet 25

3.7 Formato do Pacote Ethernet 25

3.8 Token Bus 26

3.9 Formato do Pacote Token Bus 27

3.10 a) Formato do Token 28

b) Formato do Pacote Token Ring 28

3.110 "mini-packet" da Cambridge Ring 29

4.1 Rendezvous $\quad 35$

4.2 Rendezvous Estendido 36

4.3 Tratamento de Falhas em RPCs 40

4.4 Chamada de Procedimento Remoto 42

4.5 Desempenho Típico de uma Chamada Remota 46

5.1 Estrutura do Hardware do SPP 51

5.2 Definição dos Pacotes de Dados 55

5.3 Diagrama de Estrutura Modular - Estação 57

5.4 Diagrama de Estrutura Modular - Servidor $\quad 58$

5.5 Diagrama de Estrutura Modular - ISERVER $\quad 59$

5.6 Incorporação do Núcleo RPC ao Servidor INMOS 59

5.7 Seqüência de Requisições $\quad 62$

5.8 Estrutura em Camadas do Software $\quad 64$ 
6.1 Ambiente de desenvolvimento 68

6.2 Diagrama de Estrutura Modular - Programa net 73

6.3 Diagrama de Estrutura Modular - Programa net modificado 74

6.4 Diagrama de Estrutura Modular - Programa net (SPP - servidor) 75

6.5 Diagrama de Estrutura Modular - Programa net (SPP - estação) 76

A.1 SPP após a alocação de 3 Procs. 96

A.2 ET ligada diretamente ao processador Transputer 97

\section{Índice das Tabelas}

6.1 Serviços Disponíveis no Sistema net 69

6.2 Linha de Entrada do Arquivo "/FTPUSERS" 71

6.3 Organização Lógica da Implementação do Programa net 72

7.1 Dados Obtidos para o Primeiro Teste - login 81

7.2 Dados Obtidos para o Primeiro Teste - logout 82

7.3 Dados Obtidos para o Primeiro Teste - lot 82

7.4 Dados Obtidos para o Primeiro Teste - dlot 83

7.5 Dados Obtidos para o Segundo Teste - Sessão Mínima 84

7.6 Faixa de Tamanho de Arquivos para Teste 85

7.7 Resultados Comparativos com TCP/IP $\quad 85$

\section{Índice dos Gráficos}

7.1 Análise das Primitivas para o Primeiro Teste 83

7.2 Análise de uma Sessão Mínima para as duas Semânticas $\quad 84$

7.3 Análise das Três Versões Implementadas $\quad 86$ 


\section{Glossário}

\begin{tabular}{|c|c|}
\hline$\overline{\mathrm{BT}}$ & $\begin{array}{l}\text { Banco de Transputers. Constituído pelos processadores, controlador } \\
\text { de banco, controladores de módulo, rede de chaveamento e } \\
\text { componentes do software do sistema relacionados com a sua } \\
\text { operação básica. Apresenta uma estrutura expansível, baseada em } \\
\text { módulos. }\end{array}$ \\
\hline $\mathrm{CB}$ & $\begin{array}{l}\text { Controlador do Banco. Computador responsável pelo controle do } \\
\text { banco de Transputers. Comunica-se com os controladores de } \\
\text { módulo e com o processador de entrada. }\end{array}$ \\
\hline $\mathrm{CM}$ & $\begin{array}{l}\text { Controlador de Módulo. Computador responsável pelo controle de } \\
\text { um módulo do banco de Transputers. Comunica-se com outros } \\
\text { controladores de módulo e/ou com o controlador do banco. }\end{array}$ \\
\hline CRC & $\begin{array}{l}\text { "Cyclic Redundancy Code". Código binário utilizado para deteç̧ão } \\
\text { de correção de erros, em particular, em pacotes de dados ethernet. }\end{array}$ \\
\hline CSP & $\begin{array}{l}\text { "Communicating Sequential Processes". Linguagem desenvolvida } \\
\text { por Hoare para especificação de sistemas concorrentes. }\end{array}$ \\
\hline$\overline{\mathrm{DEM}}$ & $\begin{array}{l}\text { Diagrama de Estrutura Modular. Diagrama utilizado em projeto } \\
\text { estruturado para representar os diversos módulos de um sistema e a } \\
\text { comunicação entre eles. }\end{array}$ \\
\hline DFD & $\begin{array}{l}\text { Diagrama de Fluxo de Dados. Diagrama utilizado em análise/projeto } \\
\text { estruturados para representar açôes sobre fluxos de dados em um } \\
\text { sistema. }\end{array}$ \\
\hline ET & Estação de Trabalho. \\
\hline ISERVER & Módulo de software servidor do sistema de desenvolvimento TDS. \\
\hline ISO & $\begin{array}{l}\text { "International Standard Organization". Organização internacional } \\
\text { voltada para o estabelecimento de normas técnicas da qual o Brasil } \\
\text { figura como país membro. }\end{array}$ \\
\hline
\end{tabular}




\begin{tabular}{|c|c|}
\hline LLC & $\begin{array}{l}\text { "Logical Link Control". Subcamada de mais alto nível da camada de } \\
\text { enlace de dados no modelo de referência ISO-OSI. }\end{array}$ \\
\hline LT & $\begin{array}{l}\text { Lote de Transputers. Conjunto de processadores Transputers } \\
\text { alocados para um usuário do servidor de processamento paralelo. }\end{array}$ \\
\hline MAC & $\begin{array}{l}\text { "Medium Access Control". Subcamada de mais baixo nível da } \\
\text { camada de enlace de dados no modelo de referência ISO-OSI. }\end{array}$ \\
\hline NCSA & \begin{tabular}{|l|} 
National Center for Supercomputer Applications. \\
\end{tabular} \\
\hline OCCAM & $\begin{array}{l}\text { Linguagem de alto nível baseada na linguagem CSP. Dispõe de } \\
\text { mecanismos intrinsecos para a sincronização de processos } \\
\text { concorrentes. }\end{array}$ \\
\hline$\overline{\text { OSI }}$ & $\begin{array}{l}\text { "Open Systems Interconnection" - Reference Model. Modelo de } \\
\text { referência ISO para conexão de sistemas abertos. }\end{array}$ \\
\hline PD & $\begin{array}{l}\text { "Packet Driver" - NCSA . Mecanismo para acesso e multiplexação } \\
\text { de pacotes de dados implementado na universidade de Clarkson. }\end{array}$ \\
\hline $\mathrm{PE}$ & $\begin{array}{l}\text { Processador de Entrada. Computador responsável pela comunicação } \\
\text { do servidor de processamento paralelo com a rede local e pelo } \\
\text { atendimento de parte dos serviços disponiveis no SPP. }\end{array}$ \\
\hline PKT & Protocolo de comunicação utilizado pelo "Packet Driver" -NCSA. \\
\hline $\mathrm{RC}$ & $\begin{array}{l}\text { Rede de Chaveamento. Malha composta por chaves eletrônicas } \\
\text { utilizada para o roteamento de dados entre os processadores. }\end{array}$ \\
\hline REDE LOCAL & $\begin{array}{l}\text { Componentes de hardware e software relacionados com a conexão } \\
\text { de estações de trabalho e servidores. }\end{array}$ \\
\hline RESET & $\begin{array}{l}\text { Sinal de reiniciação aplicado em Transputers para o estabelecimento } \\
\text { das condições iniciais de funcionamento. }\end{array}$ \\
\hline RPC & $\begin{array}{l}\text { "Remote Procedure Call". Mecanismo para chamada de } \\
\text { procedimentos remotos. Utilizado neste trabalho para implementar a } \\
\text { comunicação entre os pares servidor - cliente. }\end{array}$ \\
\hline SP & $\begin{array}{l}\text { "Server Protocol" - INMOS. Protocolo utilizado para comunicação } \\
\text { entre o programa iserver e redes de Transputers. }\end{array}$ \\
\hline
\end{tabular}




\begin{tabular}{|l|l|}
\hline SISTEMA SPP & $\begin{array}{l}\text { Todos os itens de hardware e software relacionados com a operação } \\
\text { do servidor de processamento paralelo. }\end{array}$ \\
\hline SPP (1) & $\begin{array}{l}\text { Servidor de Processamento Paralelo. Constituído pelo banco de } \\
\text { Transputers, pelo processador de entrada, processadores, e } \\
\text { componentes do software do sistema responsáveis pela operação } \\
\text { básica desses. }\end{array}$ \\
\hline SPP (2) & $\begin{array}{l}\text { Protocolo de comunicação utilizado pelo mecanismo de chamadas a } \\
\text { procedimentos remotos utilizado no servidor de processamento } \\
\text { paralelo. }\end{array}$ \\
\hline TCP/IP & $\begin{array}{l}\text { "Transmission Control Protocol/Internet Protocol". Conjunto de } \\
\text { protocolos de comunicação utilizados em redes de computadores } \\
\text { locais e de grande distância. }\end{array}$ \\
\hline TDS & $\begin{array}{l}\text { "Transputer Development System". Sistema para o desenvolvimento } \\
\text { de software em Transputers. Inclui editor de textos baseado em } \\
\text { dobras ("folds"), compilador OCCAM, editor de ligação, depurador, } \\
\text { carregadores e diversos outros programas utilitários. }\end{array}$ \\
\hline TRANSPUTER & $\begin{array}{l}\text { Microcomputador fabricado pela INMOS. Possui características que } \\
\text { o tornam indicado como elemento básico na implementação de } \\
\text { máquinas paralelas. }\end{array}$ \\
\hline UC & $\begin{array}{l}\text { Unidade de Controle. Subsistema de um computador responsável } \\
\text { pela busca, interpretação e execução das instruções. }\end{array}$ \\
\hline
\end{tabular}




\section{Resumo}

Uma arquitetura para processamento paralelo baseada em um banco de transputers, foi desenvolvida e implementada com sucesso no LaSD (Laboratório de Sistemas Digitais) ICMSC-USP [TR91]. Essa arquitetura (SPP - Servidor de Processamento Paralelo) introduz recursos de processamento paralelo para os usuários de um sistema distribuído baseado em rede local de computadores.

Neste trabalho são revisados alguns pontos básicos que ficaram pendentes na implementação original do software do SPP. Uma nova semântica de comunicação é implementada ("at-least-once") e os resultados obtidos na comparação com a semântica original ("at-most-once") são analisados.

É apresentada uma nova implementação das primitivas de comunicação do SPP baseada na utilização do protocolo TCP/IP, visando maior abrangência no acesso remoto ao sistema.

O trabalho discute as diretrizes básicas seguidas no projeto, implementaçã̃o e os resultados obtidos nos testes efetuados. 


\section{Abstract}

An architecture for parallel processing based on a bank of transputer was developed and successfully implemented at LaSD (Laboratório de Sistemas Digitais) ICMSC-USP [TR91]. This architecture (SPP- Servidor de Processamento Paralelo) provides parallel processing resources to users of a distributed LAN-based computing system.

This work presents a review of the original SPP software implementation. A new communication semantics ("at-least-once") is implemented and discussed and the results obtained from the comparison to the original semantics ("at-most-one") are also discussed.

A new implementation of the SPP communication primitives using the TCP/IP protocol is also introduced aiming at increasing the remote access facilities to the system.

This work also presents the basic approach used in the project, implementation and tests realized. 


\section{Capítulo 1}

\section{Introdução}

O hardware e o software dos sistemas computacionais têm sofrido constante evolução. $O$ hardware atravessou quatro gerações que foram caracterizadas pela tecnologia dos componentes utilizados na sua implementação. Inicialmente eletromecânicos, surgiram posteriormente as válvulas, transistores e finalmente os circuitos integrados. A evolução do hardware tem se caracterizado pelo aumento da velocidade de processamento e pela redução do espaço fisico e consumo de energia. $\mathrm{O}$ software operacional evoluiu dos carregadores de código em linguagem de máquina, sistemas operacionais monousuários, sistemas operacionais multiusuários em tempo compartilhado até os sistemas operacionais distribuídos. A feliz combinação do hardware, mais acessivel e de maior desempenho, com os sistemas operacionais distribuídos e as redes de computadores, introduz aos usuários recursos computacionais nunca antes proporcionados pelos sistemas até então existentes.

Sistemas Distribuídos têm sido projetados para possibilitar compartilhamento de recursos, fazendo com que computadores separados (muitas vezes máquinas diferentes umas das outras), interligados por uma rede local compartilhem periféricos, servidores de arquivos, de impressão e outros.

As redes de computadores estão presentes em vários ambientes de trabalho, conectando os elementos e possibilitando a troca de informações.

Os objetivos básicos de uma rede de computadores são:

- Compartilhamento de recursos.

- Confiabilidade provida pela multiplicidade de recursos.

- Economia proporcionada pela utilização de muitas estações de trabalho, ao invés de um computador centralizado, e pelo compartilhamento de recursos através de servidores especializados.

- Modularidade, ou seja, o aumento gradual na capacidade do sistema. (Vale observar que o acréscimo de uma estação de trabalho aumenta a capacidade computacional de uma rede de computadores, o que não ocorre com o acréscimo de um terminal a um sistema multiusuário por tempo compartilhado.)

- Meio de comunicação entre usuários geograficamente separados. 
Para reger a comunicação nesses sistemas interligados por uma rede, existe um conjunto de regras formais denominado protocolo de comunicação. $O$ primeiro passo dado no sentido da padronização desses protocolos utilizados, é representado pelo modelo de referência OSI ("Open Systems Interconnection"), patrocinado pela ISO ("International Standards Organization") [ZI80].

O modelo cliente-servidor representa uma alternativa natural para a implementação da comunicação em sistemas computacionais distribuídos, particularmente aqueles baseados em redes locais de computadores [TA85]. Nesse modelo, serviços são requisitados por processos cliente para processos servidores. Uma vez requisitado um serviço, o processo cliente aguarda uma resposta. Vários mecanismos podem ser adotados para a implementação desse modelo.

O mecanismo de Chamadas a Procedimentos Remotos, RPC, tem se destacado como um mecanismo simples e transparente para a implementação de sistemas distribuídos. O paradigma de chamadas a procedimentos locais, implementado na maioria das linguagens de programação, dá suporte teórico ao mecanismo RPC. A transparência ideal acontece quando os procedimentos remotos não podem ser distinguidos dos procedimentos locais. Alguns aspectos, como o acesso a parâmetros passados por referência, limitam o nível de transparência conseguido [WI87].

O Departamento de Ciências de Computação e Estatística do Instituto de Ciências Matemáticas de São Carlos, USP, conta hoje com um sistema computacional distribuído baseado em rede local (tecnologia Ethernet), composto de diversos servidores padrão (arquivos, impressão, correio eletrônico, etc), diversas estações de trabalho e um servidor especialmente desenvolvido para aplicações de computação concorrente/paralela, baseado na utilização de um banco de transputers (figura 1.1).

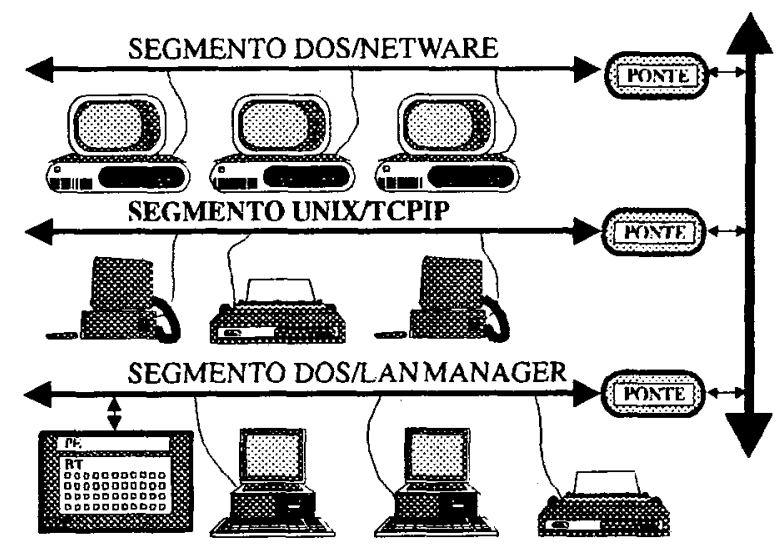

PE: Processador de Entrada do Banco. Responsável por estabelecer a comunicação entre estações e o banco, bem como gerenciar as atividades de controle dos usuários.

BT: Banco de Processamento Paralelo

Fig. 1.1 - Rede Local com Segmentos Interligados por Pontes 
A utilização de computação concorrente (ou paralela) constitui uma área de atuação interdisciplinar, de grande interesse na atualidade. A utilização do microprocessador transputer da INMOS [IN90] é uma alternativa moderna e eficiente para a implementação de ambientes voltados à elaboração de sistemas concorrentes. A abordagem adotada no Laboratório de Sistemas Digitais (LaSD) do Departamento de Ciências de Computação e Estatística, ICMSC-USP, segue a filosofia de uso compartilhado de uma máquina paralela, baseada na utilização de um banco de transputers, que permite a alocação remota (via rede) e dinâmica de um certo número de transputers, para um usuário do sistema [TR91].

O desenvolvimento e implementação do sistema computacional distribuído, bem como o servidor de processamento paralelo (SPP), foram efetuados dentro de um projeto apoiado pela FAPESP, iniciado em agosto de 1990 e concluído em Julho de 1992. Esse projeto forneceu os subsídios iniciais para se criar uma plataforma básica para os trabalhos futuros. O produto final obtido foi um pequeno, mas expressivo, sistema computacional distribuído servindo os pesquisadores do LaSD e um protótipo do SPP, que no momento já está em funcionamento experimental, descrito no capítulo 5.

Neste trabalho a implementação do sistema SPP (Servidor de Processamento Paralelo) existente no ICMSC-USP é detalhadamente estudada para levantamento de dados que permitam uma avaliação objetiva do desempenho do sistema.

Várias questões pendentes do projeto original são resolvidas, além de se propor uma nova implementação para a semântica de comunicação do núcleo de Chamadas Remotas.

É proposta uma implementação do sistema SPP utilizando-se o conjunto de protocolos TCP/IP. São mostrados os resultados obtidos nessa experiência.

Este trabalho está dividido em oito capítulos, dos quais os quatro primeiros descrevem os tópicos relacionados com a revisão bibliográfica do projeto e os quatro últimos tratam do desenvolvimento do projeto. É incluído um glossário com as principais abreviaturas e conceitos utilizados no trabalho.

O estudo de tópicos relacionados com sistemas distribuídos é apresentado no capítulo 2. O capítulo 3 apresenta noções sobre protocolos de comunicação e sobre o paradigma cliente-servidor.

No capítulo 4 discutem-se alguns mecanismos para troca de mensagens entre processos, dando maior ênfase ao mecanismo de chamada a procedimentos remotos (RPC). E ainda é feita uma análise comparativa entre o desempenho e a implementação de alguns sistemas de chamada a procedimento remoto. 
No capitulo 5 é apresentada uma visão geral do sistema SPP e todos os detalhes do estudo da implementação original do sistema. São apresentadas as alterações efetuadas com ênfase na implementação da semântica "at-least-once".

No capitulo 6 apresenta-se a utilização do protocolo TCP/IP no sistema SPP. São apresentadas as dificuldades encontradas e os resultados obtidos. $O$ software utilizado foi o Ka9Q, que é descrito em detalhes.

A análise dos resultados obtidos com as alterações efetuadas, bem como na versão original é apresentada no capítulo 7 .

No capitulo 8 são apresentadas as conclusões finais do trabalho, as contribuições e sugestões de trabalhos futuros.

No apêndice A são apresentados os procedimentos de instalação e utilização do sistema SPP original e da versão TCP/IP. 


\section{Capítulo 2}

\section{Sistemas Distribuídos}

Desde a década de 40 , quando começou a era dos computadores, até a década de 80 , tem se passado por uma revolução no uso dos computadores. A maioria das organizações tinha poucos computadores e, como não havia meios de fazer a interconexão, esses operavam independentemente. Atualmente, o desenvolvimento de redes locais com altas taxas de transmissão, aliado ao desenvolvimento de microprocessadores (de custo significantemente inferior e com potência computacional comparada à dos computadores de grande porte da década passada) são dois dos principais fatores tecnológicos que têm contribuído para a mudança desse quadro. Como resultado dessas duas tecnologias obtem-se sistemas computacionais cada vez mais complexos, caracterizados pela interconexão de vários computadores através de uma rede de comunicação [TA92].

Essa interconexão possibilita o compartilhamento de recursos, fazendo com que computadores separados, interligados pela rede local compartilhem periféricos, servidores de impressão, de arquivos, de correio eletrônico, etc. caracterizando um sistema computacional potencialmente distribuído.

Sistemas Distribuídos de propósito geral têm sido projetados para permitir que computadores individuais utilizem recursos compartilhados na rede, fornecendo facilidades flexíveis. Os usuários de um sistema distribuído têm, em geral, a impressão de estarem utilizando um único computador.

Neste capítulo são introduzidos conceitos gerais de Sistemas Centralizados e Sistemas Distribuídos, discutindo-se algumas vantagens e desvantagens desses sistemas, bem como a implementação de alguns sistemas distribuídos descritos na literatura.

\subsection{Sistemas Centralizados (SC)}

Com a união do hardware e do software, um computador pode armazenar, processar, recuperar informações, encontrar erros de grafia em textos, e muitas outras atividades. O software pode ser dividido basicamente em dois tipos: 
programas do sistema: gerenciam a operação do próprio computador, .programas aplicativos: solucionam os problemas dos usuários.

O mais fundamental de todos os programas do sistema, é o Sistema Operacional (SO), que controla os recursos disponíveis e fornece uma base sobre a qual programas de aplicações podem ser desenvolvidos [TA92]. A principal função do SO é fornecer uma interface ou máquina virtual para o programador. Essa máquina virtual apresenta ao usuário um ambiente tal que se possa abstrair-se da complexidade inerente do hardware da máquina.

A situação é mostrada na figura $2: 1$, onde na camada mais baixa está o hardware (que às vezes pode ser composto por duas ou mais camadas).

\begin{tabular}{|c|c|c|c|}
\hline Aplicativos & $\begin{array}{c}\text { Sistemas } \\
\text { Bancários }\end{array}$ & Jogos & $\begin{array}{c}\text { Programas de } \\
\text { Aplicação }\end{array}$ \\
\hline Editores & Compiladores & Interpretadores & \multirow{2}{*}{$\begin{array}{c}\text { Programas do } \\
\text { Sistema }\end{array}$} \\
\hline \multicolumn{2}{|c|}{ Sistema Operacional } & \multirow{2}{*}{ Hardware } \\
\hline \multicolumn{2}{|c|}{ Linguagem de Máquina } & \\
\hline \multicolumn{2}{|c|}{ Microprogramação } & \\
\hline
\end{tabular}

Fig. 2.1 - Representação de um computador como uma máquina virtual

Acima do hardware está o Sistema Operacional com a principal função de esconder do usuário a complexidade do hardware, tornando o sistema mais flexível. Depois do Sistema Operacional está o restante do software do sistema. Encontra-se nessa camada interpretadores de comandos, compiladores, editores e outros. Finalmente na camada mais alta, encontram-se os programas aplicativos, que são programas escritos pelos usuários para solucionar seus problemas particulares.

Segundo [TA92] um sistema operacional multiprogramado pode ser decomposto em quatro grandes componentes, a saber: Gerenciador de Processos, Gerenciador de Memória, Gerenciador de Entrada/Saída e o Sistema de Gerenciamento de Arquivos. Quando o sistema possui mais que uma unidade central de processamento, operando paralelamente, existem diversos problemas que exigem a modificação da estrutura do sistema operacional para oferecer alguma flexibilidade.

Neste trabalho considera-se um conjunto de máquinas baseadas na arquitetura de Von Neumann, interligados por uma rede local de computadores. Essa interligação das máquinas faz com que seja necessário alterar a estrutura do sistema operacional, o que 
sugere a criação de uma máquina abstrata que gerencie e flexibilize a utilização dos recursos disponíveis na rede. A seguir são apresentados alguns dos elementos dessas máquinas abstratas que permitem caracterizá-los como um sistema operacional distribuído.

\subsection{Caracterização de Sistemas Distribuídos (SD)}

Não existe uma característica ou regra única que distinga os sistemas distribuídos. Lelann [LE81] discute alguns objetivos e define algumas características principais desses sistemas. Entre os objetivos destacam-se a extensibilidade, a maior disponibilidade e um melhor compartilhamento de recursos. As características discutidas por ele são: a existência de uma multiplicidade de elementos semelhantes, elementos de processamento interconectados, transparência, a ausência de estruturas de controle hierárquico e a existência de processos com espaços de endereços separados que se comuniquem via um mecanismo explícito de troca de mensagem. A transparência é definida como a 'omissão' da separação entre usuário e programador da aplicação, de tal maneira que o sistema seja considerado único e não como uma coleção de componentes independentes [CO88].

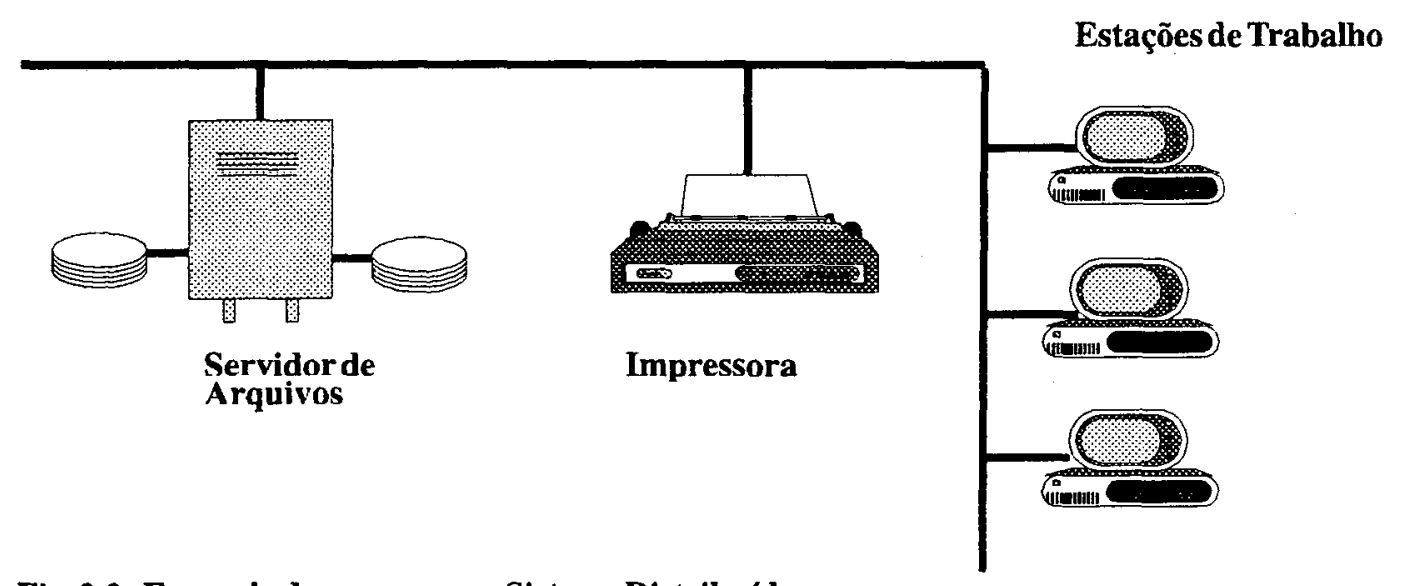

Fig.2.2-Exemplo de um pequeno Sistema Distribuído

As propriedades fundamentais de um sistema distribuído (fig. 2.2) são tolerância à falhas e a possibilidade de se utilizar paralelismo. Atualmente não há consenso a respeito dos requisitos a serem satisfeitos para que um sistema seja considerado distribuído, e nem de como pode-se reconhecer se um sistema é ou não é distribuído [MU89].

Tanenbaum e van Renesse [TA85] apresentam a seguinte definição:

"Um sistema operacional distribuido é aquele que para os seus usuários parece ser um sistema operacional centralizado, mas que é executado em várias CPUs independentes. 
O conceito chave é a transparência, isto é, a utilização dos vários processadores é invisivel para o usuário. Uma outra forma de se expressar essa idéia é dizer que o usuário 'enxerga' o sistema como se fosse uma única máquina e não como uma coleção de máquinas distintas."

Essa condição é necessária para que um sistema seja distribuído, mas acredita-se que ela não seja suficiente [MU89]. Um sistema distribuído deve ter pontos isolados de falha - se alguma dessas partes falhar, o sistema não pode parar como um todo.

Em [TA92], Tanenbaum define um sistema distribuido da seguinte maneira:

"Um sistema distribuido é um sistema que é executado em uma coleção de máquinas que não possuem memória compartilhada e para o usuário parece ser um computador único."

Essa propriedade é, às vezes, referenciada como a 'imagem de um sistema único'. Outras vezes, de uma forma diferente, dizendo que um sistema distribuído é um sistema que é executado em uma coleção de máquinas interligadas por uma rede, agindo como um 'uniprocessador virtual'. Não importa como esse conceito seja colocado, a idéia essencial é que os usuários não podem ter consciência da existência de várias CPUs no sistema.

Schroeder [SC84,SC82] lista alguns sintomas para se reconhecer sistemas distribuídos, que são apresentados a seguir. Se um sistema possuir todos eles, ele provavelmente é um sistema distribuído.

- múltiplos elementos processadores,

- interconexão de hardware,

- falha independente dos elementos processadores,

- o estado do sistema deve ser compartilhado.

O projeto de sistemas distribuídos é de difícil entendimento devido principalmente à sua complexidade. Essa complexidade vem da interligação de componentes conhecidos, que quando interligados, geram novos problemas (por exemplo, o sincronismo entre processos).

\title{
2.3 Vantagens e Desvantagens (SD X SC)
}

\author{
Vantagens:
}


- Economia:

- Velocidade:

- Distribuição inerente:

- Confiabilidade: microcomputadores oferecem uma relação custo/beneficio melhor que os computadores de grande porte,

um sistema distribuído pode ter potência computacional maior que os computadores de grande porte,

algumas aplicações envolvem máquinas separadas espacialmente,

se uma máquina sair do ar, o sistema ainda pode, como um todo, manter-se ligado,

- Crescimento gradual: o sistema pode crescer incrementalmente.

Partindo-se do princípio que microcomputadores fornecem uma maneira efetiva de se trabalhar, porque não fornecer um computador pessoal (PC) para cada indivíduo, permitindo-se que trabalhem independentemente? Em primeiro lugar devido à necessidade de compartilhamento de dados pór parte dos usuários. Esse compartilhamento de dados é essencial para várias aplicações, e nesse caso as máquinas devem estar interconectadas. Ao fazer a interconexão das máquinas pode-se compartilhar também os periféricos caros e pouco utilizados, como impressoras a laser, plotters, etc. Uma outra razão para se conectar um grupo de computadores isolados num sistema distribuído é alcançar uma comunicação pessoa-a-pessoa, via correio eletrônico. Não esquecendo de realçar que os sistemas distribuídos fornecem uma maior mobilidade ao usuário. Finalmente, um sistema distribuído é potencialmente mais flexível!

\section{Desvantagens:}

Um dos problemas mais sérios relacionados com sistemas distribuídos é o software. Ainda não se tem muita experiência no projeto, implementação e utilização de software distribuído. Quanto mais pesquisa se tem feito, menor tem se tornado o problema, mas mesmo assim ele ainda não pode ser ignorado. Um segundo problema está relacionado com a rede de comunicação. Ela pode perder mensagens, o que requer gerenciamento especial por software e ainda pode se tornar sobrecarregada. Finalmente, o compartilhamento de dados, que foi citado como uma vantagem, pode se tornar uma "faca de dois gumes", pois segurança é freqüentemente um problema.

Mesmo com esses problemas, acreditam-se que as vantagens são maiores que as desvantagens e esperam-se que os sistemas distribuídos se tornem a cada dia mais importantes [TA92] 


\subsection{Modelos para Projeto de Sistemas Distribuídos}

\subsubsection{Pontos Relevantes ao Projeto}

Sistemas distribuidos devem ser projetados cuidadosamente. Alguns tópicos a serem observados no desenvolvimento desses sistemas são [TA92]:

.transparência: esconder a distribuição dos usuários e dos programas aplicativos, flexibilidade: como o campo de estudo está em constante crescimento, o projeto deve ser feito com o intuito de facilitar futuras mudanças,

. confiança: se uma máquina quebra, uma outra máquina assume a tarefa.

. desempenho: construir um sistema distribuído transparente, flexível e confiável não é suficiente, é necessário que ele tenha um bom desempenho.

. escalabilidade: os sistemas são projetados para um número de CPUs, podendo esse número ser alterado.

\subsubsection{Modelos}

Quando o compartilhamento de recursos de um sistema distribuído é efetivado através da transferência de dados entre os diversos computadores do sistema, através de uma rede de comunicação, diz-se que esse é um sistema fracamente acoplado. Uma outra categoria de sistemas são os denominados fortemente acoplados, assim chamados por explorarem unidades múltiplas de processamento, que geralmente compartilham algum espaço de memória ou endereço com o objetivo de alcançar alto desempenho.

Para o desenvolvimento de sistemas distribuídos fracamente acoplados existem basicamente três modelos arquiteturais, que definem a organização do sistema: modelo estação de trabalho/servidor, modelo banco de processadores e modelo integrado.

No modelo Estação de Trabalho/Servidor cada usuário possui uma estação de trabalho com potência computacional para executar aplicativos, mas muitas aplicações requerem acesso a informações compartilhadas, através da rede de comunicação. As estações são integradas pelo uso de software de comunicação que permite que todas as estações tenham acesso a um conjunto de arquivos (fig. 2.3). Esse modelo utiliza normalmente uma organização cliente/servidor, descrita no capítulo 3 . 


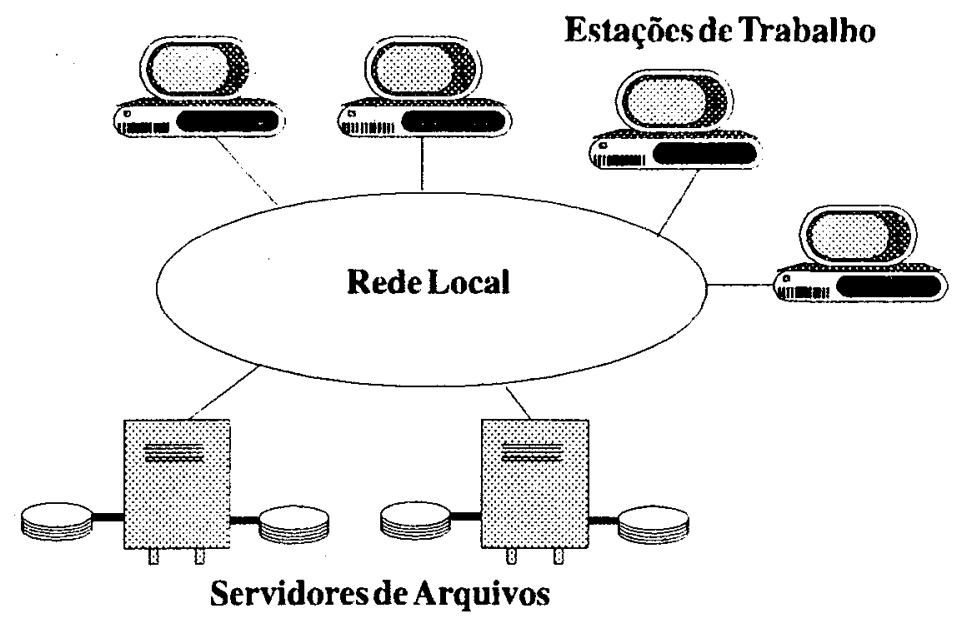

Fig. 2.3 - Modelo Estação de Trabalho-Servidor

No modelo Banco de Processadores (fig. 2.4) os programas são executados num conjunto de computadores gerenciados como um serviço de processadores. Os usuários utilizam terminais, ao invés de estações de trabalho, conectados à rede via concentradores e interagem com os programas via um protocolo de acesso a terminais. A maior restrição deste modelo está no fato de se utilizar terminais. Como estações de trabalho estão disponíveis em grande número hoje em dia, e estão incluídas na maior parte dos sistemas computacionais, surgiu daí o modelo Híbrido, que é baseado no modelo Estação de Trabalho/Servidor, com a adição de um banco de processadores, que pode ser alocado dinamicamente para tarefas onde a estação de trabalho não é considerada adequada.

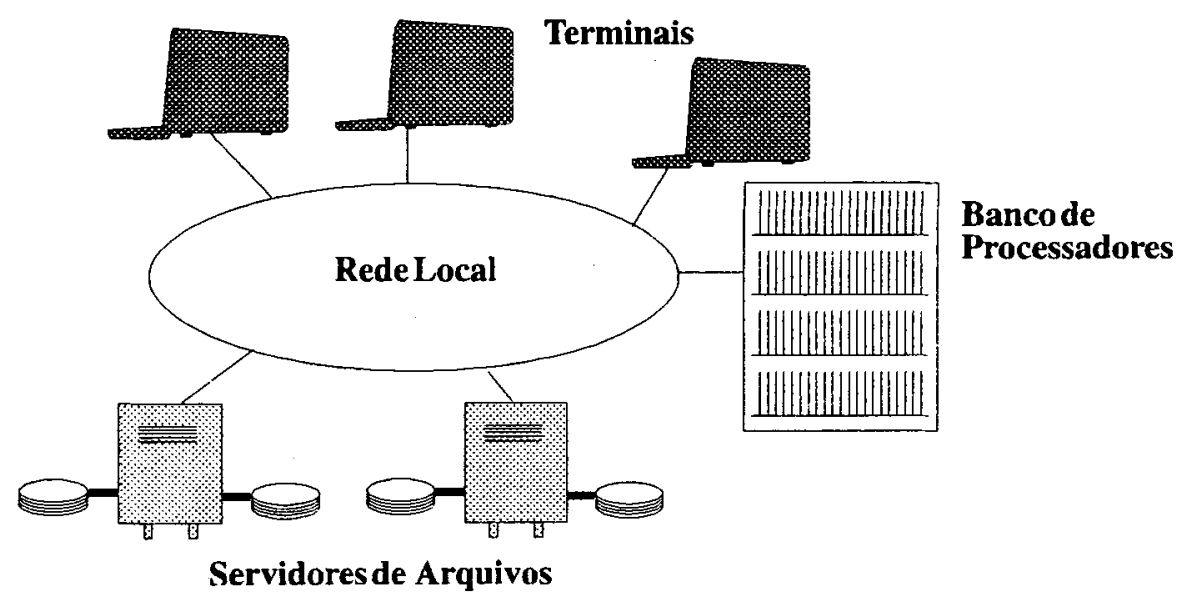

Fig. 2.4 - Modelo Banco de Processadores

O modelo Integrado apresenta as vantagens de sistemas distribuídos para redes que contêm ambientes computacionais mono e multi-usuário. Cada computador possui o 
software apropriado para que ele seja tanto o servidor e processador da aplicação. $O$ software localizado em cada computador é parecido com um sistema operacional para sistemas centralizados multi-usuário, acrescentando o sistema de rede (fig. 2.5).

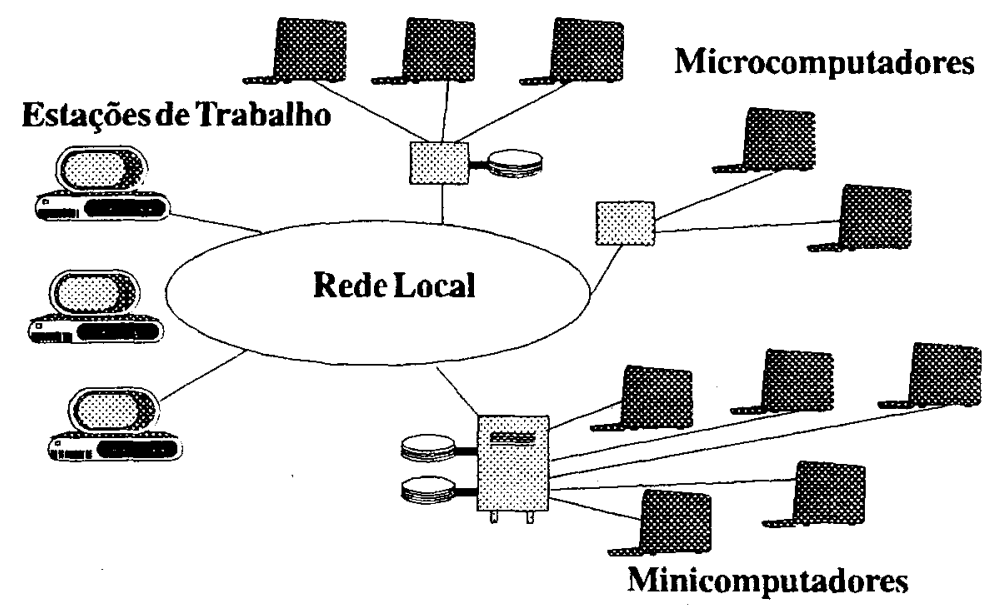

Fig. 2.5 - Modelo Integrado

\subsection{Exemplos de Sistemas Distribuídos}

Diversos sistemas distribuídos têm sido implementados em diferentes ambientes. A seguir são discutidos alguns desses sistemas.

\section{TRICE}

Sistema distribuído desenvolvido na Universidade de Southampton, Inglaterra [SA90]. Esse sistema utiliza a rede local de comunicação Cambridge Ring [HO80]. A topologia do sistema é em estrela anel ("star ring") onde estão interconectadas diversas redes, conforme ilustra a figura 2.6 .

O sistema foi desenvolvido com o objetivo de auxiliar o ensino e a pesquisa, e foi organizado de acordo com o modelo estação/servidor. O sistema TRICE foi projetado segundo o paradigma cliente/servidor e implementou-se um mecanismo para comunicação entre processos baseado em "chamadas de procedimentos remotos" (também conhecido por "RPC - Remote Procedure Calls").

O sistema TRICE, até janeiro de 1990, possuia mais de 150 estações de trabalho, 10 servidores de arquivos, 4 servidores de impressão e aproximadamente 500 usuários. 
Possui alto desempenho e relativa transparência.

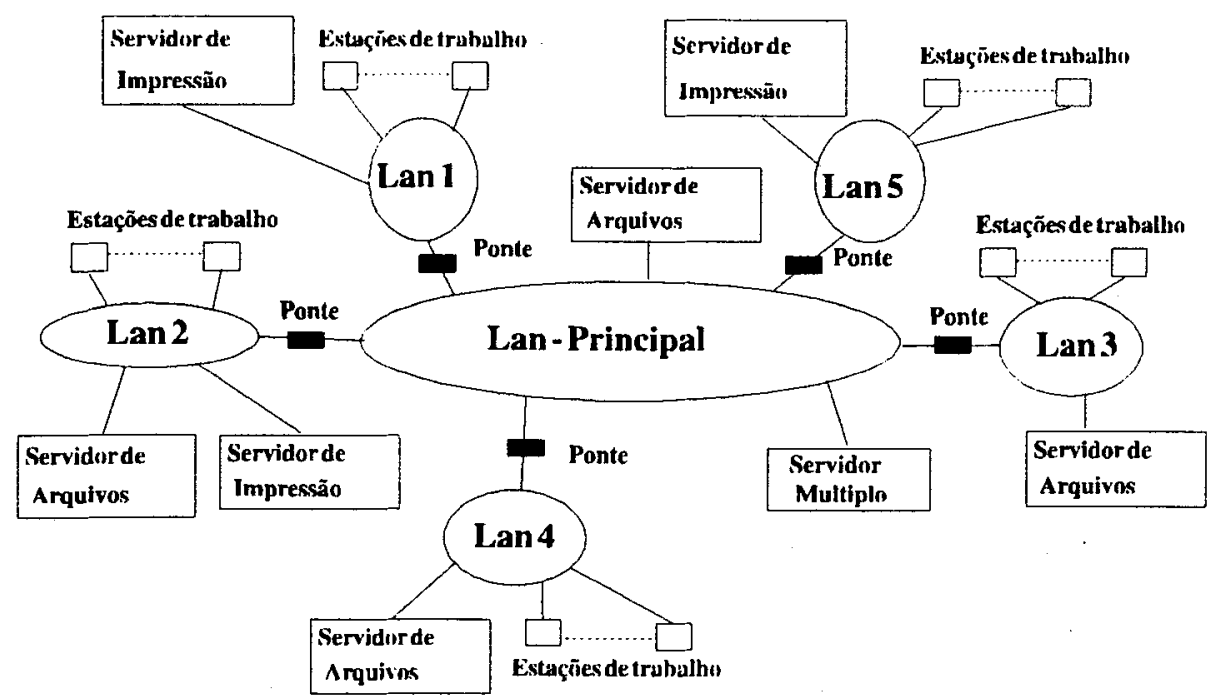

Fig 2.6 - Sistema Trice

Os usuários do sistema TRICE têm a ilusão de ter todos os recursos do sistema conectados diretamente às suas estações de trabalho. O ambiente do sistema TRICE é baseado em sessões: o usuário estabelece uma sessão de trabalho com um servidor de arquivos antes de começar a trabalhar, e a transparência nesse ambiente é total, desde que o usuário tenha autorização para ter acesso a qualquer arquivo. $O$ acesso a outros servidores de arquivos não é tão transparente. Esse acesso só é permitido através de um conjunto explícito de comandos. Os servidores de arquivos trabalham isoladamente e por isso existem ferramentas para se transferir arquivos de um servidor para outro, ou para transferir o usuário de uma sessão para outra [SA90].

\section{AMOEBA}

O sistema Amoeba foi originalmente projetado e implementado na Universidade de Vrije, Amsterdã. $\mathrm{O}$ sistema vem sendo desenvolvido há vários anos e possui as seguintes características:

existe uma biblioteca de procedimentos que emula as funções do sistema UNIX, permitindo que programas UNIX sejam executados no sistema Amoeba.

. o sistema possui vários utilitários incluindo compiladores, editores e 'shells'. 
A arquitetura do sistema consiste em quatro componentes principais: estações de trabalho, banco de processadores, servidores especializados e os 'gateways' que são utilizados para a interligação de sistemas Amoeba em lugares ou países diferentes [TA90]. O sistema é um exemplo real do modelo híbrido. Esta "visão" fornece muitas das vantagens dos dois modelos envolvidos. Os usuários podem utilizar programas interativos ou de aplicação gráfica nas estações, enquanto têm disponível uma variedade de bancos de processadores de tipos e desempenhos diferentes para executar programas para os quais as estações não são adequadas ou mesmo executar tarefas que requerem mais de um processador.

Estações de Trabalho

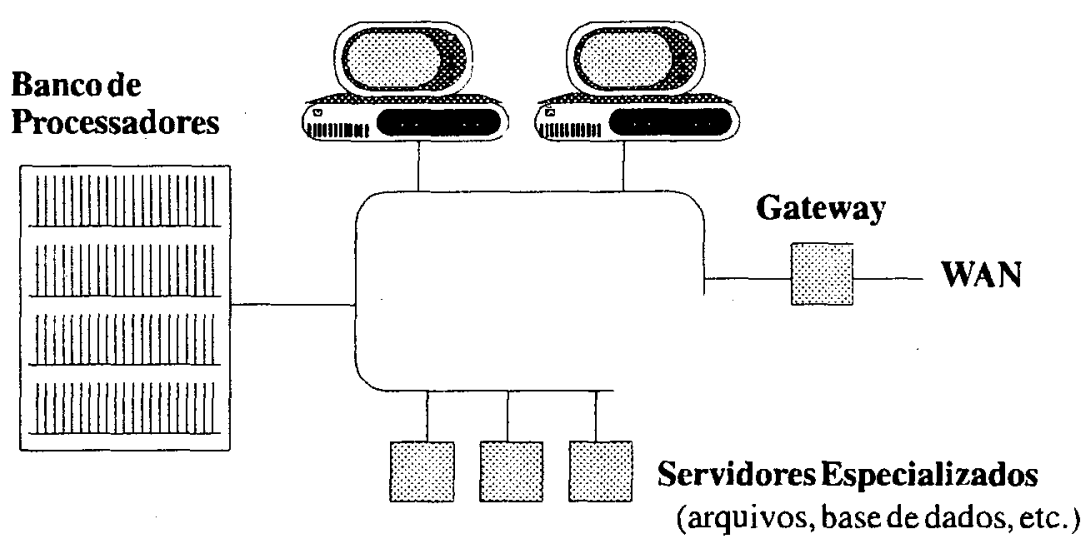

Fig 2.7 - A Arquitetura do Sistema Amoeba

Para os usuários, utilizar o sistema Amoeba é como se eles utilizassem um sistema multi-usuário tradicional, como o UNIX. Uma pessoa abre uma sessão no sistema, edita e compila programas, move arquivos e outras operações. A diferença é que cada uma dessas ações utiliza várias máquinas espalhadas pela rede. Elas incluem servidores de processos, servidores de arquivos, servidores de diretório, e outras máquinas, mas o usuário não sabe disso.

Uma importante diferença entre o sistema Amoeba e a maioria dos sistemas distribuídos é que no sistema Amoeba não existe o conceito de "home machine". Quando um usuário abre uma sessão no sistema, não é para uma máquina específica e sim para o sistema como um todo. As máquinas não têm donos, isto significa que todos os recursos pertencem ao sistema como um todo, e são gerenciados por ele [CO88].

O objetivo principal do projeto Amoeba é construir um sistema transparente para os usuários [TA90]. Um objetivo secundário do sistema Amoeba é fornecer um suporte para programação paralela e distribuída, tornando o paralelismo disponivel para os usuários interessados. (A linguagem ORCA, por exemplo, foi projetada e implementada no sistema Amoeba para programação paralela.) 


\section{LOCUS}

O Sistema Distribuído Locus foi desenvolvido por Popek e seu grupo [PO81], na Universidade da California, Los Angeles, e está em operação na UCLA por vários anos.

Locus é um sistema distribuído "UNIX-like". Os programas aplicativos são executados em ambiente UNIX simulado, só que com um grande sistema de nomeação de arquivos, sistema de armazenamento de arquivos com replicação e a habilidade de executar processos remotamente. O sistema fornece um alto grau de transparência, no que diz respeito ao local da execução do processo. O sistema Locus foi implementado em computadores Vax e foi estendido para incluir vários tipos de computadores que formam um sistema heterogêneo. Os usuários têm acesso ao sistema através de terminais. Os Vaxs e os outros computadores agem tanto como clientes ou como servidores de arquivos; cada Vax armazena alguns dos arquivos e programas cliente podem ter acesso a arquivos locais ou remotos. Isto é, o sistema distribuído parece ser, para o usuário, um sistema UNIX gigante, com todos os computadores sendo clientes e servidores e com o acesso a arquivos do UNIX, criação de processos e primitivas de comunicação entre processos implementados transparentemente através da rede. Novos processos podem ser criados pelos programas clientes e executados em um computador apropriado, selecionado sem o conhecimento ou intervenção do cliente. Uma exceção à transparência geral da implementação distribuida é que é possível escolher o tipo e a potência (memória e velocidade) da máquina na qual será executado o processo [CO88].

\section{CAMBRIDGE}

O sistema distribuído de Cambridge é altamente utilizado como um ambiente de pesquisa, é baseado na rede local Cambridge Ring [HO80], e foi desenvolvido de acordo com o modelo Banco de Processadores. A infra-estrutura é fornecida por um número de pequenos nós de serviço que dão suporte ao gerenciamento do banco de processadores e à chamada de serviços comuns pelos diferentes sistemas de banco de processadores. $O$ maior enfoque dado na pesquisa para seu desenvolvimento foi na distribuição das funções pelo sistema e na sua comunicação. A solicitação por um processador do banco, ao Gerenciador de Recursos, é uma utilização típica do sistema. O usuário especifica o software a ser carregado no processador requisitado e então executa aplicativos nesta máquina. Apesar do usuário poder requisitar mais do que uma máquina, o sistema de Cambridge original, não fornece suporte para que os usuários dividam a tarefa entre as várias máquinas.

O sistema de Cambridge está implementado com três Cambridge Rings, ligadas por pontes. O ambiente de desenvolvimento fornecido através do servidor de arquivos e do banco de processadores, foi aumentado por dois Vax com sistemas Unix, com discos locais e alguns micros Vax2 interligados por uma rede baseada na Ethernet [BA87]. 
Um banco de processadores pode conter sistemas de software e de hardware diferentes, e cada sistema pode ter sua própria implementação de proteção, nomeação, segurança, etc. A maior vantagem desse modelo é que novos sistemas podem estar disponíveis ao usuário sem muitas mudanças no sistema. Um outro ponto a se considerar no sistema Cambridge é que ele permite que tais sistemas compartilhem serviços comuns, como impressoras e discos [BA87].

\subsection{Considerações Finais}

Em sistemas distribuidos, as atividades são geralmente processadas em mais de um computador e esses computadores se comunicam através de uma rede de comunicação.

Um dos principais objetivos no projeto de sistemas distribuídos é tornar transparente (para o usuários) que os elementos processadores estão localizados em computadores diferentes.

As vantagens de se utilizar sistemas distribuídos são: velocidade, economia (quando comparados à computadores de grande porte), extensibilidade, facilidade de se compartilhar recursos e informações e confiabilidade (várias máquinas ligadas, se uma falhar, a outra assume a tarefa). Algumas das desvantagens estão relacionadas com o software de sistemas distribuídos. O compartilhamento de dados também requer muito cuidado, pois está relacionado com a segurança do sistema.

As redes de comunicação são componentes importantes de sistemas distribuídos. No próximo capítulo serão discutidos os protocolos de comunicação, que são de vital importância no contexto de Sistemas Distribuídos, regendo a comunicação entre processos servidores e processos clientes. 


\section{Capítulo 3}

\section{Protocolos de Comunicação}

As Redes de Computadores se tornaram parte integral de vários ambientes de trabalho, promovendo comunicação interna e compartilhamento de recursos. No contexto de Sistemas Distribuídos, as redes de computadores desempenham papel fundamental conectando os seus componentes e possibilitando a troca de informações. Este fato tem incentivado pesquisas de tecnologias de rede com alto desempenho e confiabilidade, com o objetivo de tornar viável a implementação de sistemas distribuídos mais eficientes e capazes de atingir áreas geográficas cada vez maiores.

Para especificar e estabelecer convenções utilizadas na comunicação entre módulos semelhantes de software que são executados em computadores diferentes ligados por uma rede, existe um conjunto de regras formais denominado protocolo de comunicação. O objetivo de se utilizar protocolos em sistemas distribuídos é reger a comunicação nesses sistemas, tornando viável a interconexão de sistemas abertos [CO88].

Neste capítulo apresentam-se alguns dos protocolos de comunicação mais utilizados e descrevem-se algumas tecnologias de redes.

\subsection{O Modelo de Referência OSI}

Geralmente, uma rede de computadores é heterogênea, ou seja, existem vários computadores de diferentes fabricantes. Se cada fornecedor desenvolver seu próprio protocolo, dificilmente estas máquinas se comunicarão. Por esta razão, a ISO ("International Standards Organization") está desenvolvendo propostas de padronização que possibilitem a interligação de vários tipos de máquinas. Visando facilitar a especificação dos padrões propostos foi criado um modelo de referência denominado OSI ("Open System Interconnection"). O modelo ISO-OSI [ZI80] está voltado para o desenvolvimento de sistemas abertos, ou seja, sistemas capazes de atender solicitações de serviços provindos de outros sistemas remotos.

A maioria das redes modernas são estruturadas em camadas dispostas hierarquicamente, de modo que uma determinada camada deve oferecer um conjunto de serviços à camada superior. Dessa forma, a camada n de uma máquina comunica-se com 
a camada $n$ da outra, seguindo um conjunto de regras denominado protocolo da camada $n$ [TA89]. Cada nível presta serviços ao nível superior a ele e recebe serviços do nível inferior, num processo de cooperação, com o objetivo único de realizar a comunicação entre sistemas de uma forma segura.

O Modelo de referência ISO/OSI tem sete camadas: física, enlace de dados, rede, transporte, sessão, apresentação e aplicação. As camadas estão representadas na figura 3.1 e descritas abaixo.

\begin{tabular}{|c|}
\hline Aplicação \\
\hline Apresentação \\
\hline Sessão \\
\hline Transporte \\
\hline Rede \\
\hline Enlace de Dados \\
\hline Física \\
\hline
\end{tabular}

Fig. 3.1 - O Modelo de Referência ISO/OSI comunicação.

Camada Física: é responsável pela transmissão de bits através do canal de

Camada Enlace de Dados: esse nível lida com os "frames" e adiciona ou remove cabeçalhos que envolvem o conteúdo real dos dados. $O$ objetivo principal desta camada é o de detectar e, possivelmente, corrigir os erros que possam ocorrer na troca de informações (bits) a nível da camada física.

Camada de Rede: é responsável pelo controle de operação da sub-rede. Essa camada fornece meios para estabelecer, manter e terminar conexões de rede entre sistemas que estejam se comunicando. É também responsável por determinar como os pacotes são roteados da origem até o destino.

Camada de Transporte: a função básica dessa camada é aceitar dados da camada de sessão, dividí-los em unidades menores, se necessário, passá-los para a camada de rede e assegurar que esses dados chegaram corretamente no outro lado. $O$ controle de erros, a verificação de seqüência, o tratamento de pacotes duplicados e o controle de fluxo são as principais funções efetuadas nesse nível.

Camada de Sessão: o objetivo dessa camada é organizar, sincronizar o diálogo e gerenciar a troca de dados entre as entidades da camada de apresentação que estejam se comunicando. Manipula o estabelecimento e o encerramento do fluxo de dados de estação a estação.

Camada de Apresentação: essa camada é responsável pela interpretação da 
sintaxe e da semântica das informações trocadas. Manipula a conversão dos dados de um formato para outro.

Camada de Aplicação: neste nível são manipulados todos os aspectos de utilização da rede em si. As aplicações são executadas nesse nível e os níveis inferiores apoiam a execução dessas aplicações.

Considere a figura 3.2. Se os "hosts" A e B estão interconectados através dos nós 1 e 2 , uma mensagem de $A$ para $B$ é tratada nesses nós por somente três camadas: a camada física, a camada enlace de dados e a camada de rede.

Os protocolos usados para conectar cada "host" aos nós da rede são denominados "Protocolo de Acesso à Rede"; aqueles usados para comunicação entre nós contínuos do caminho são chamados Protocolos de Rede Interno e aqueles associados às camadas usadas do "host" fonte ao "host" destino são denominados Protocolos "end-to-end".

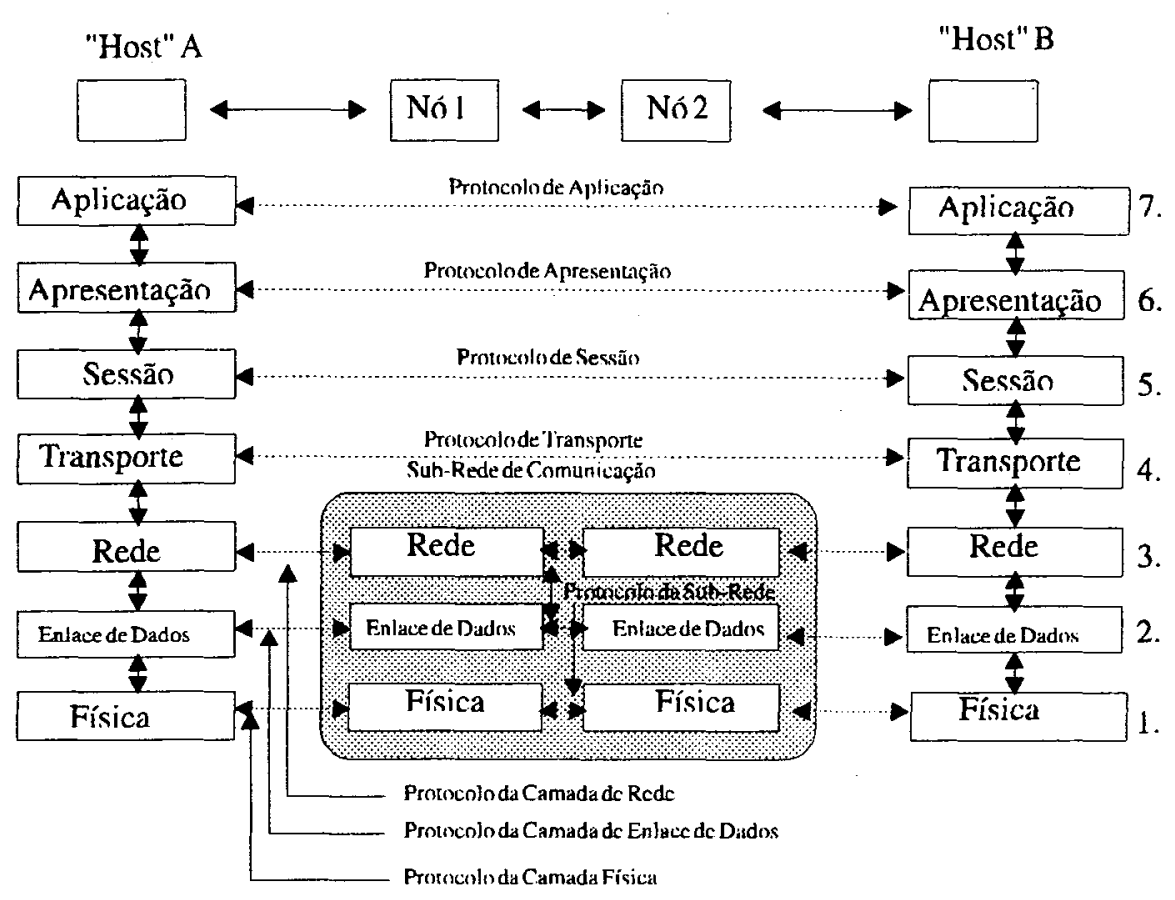

Fig. 3.2-Comunicação entrens Prncessns de Aplicações nos Hospedeirns A e B através de dois nós da Rede.

A utilização do modelo ISO-OSI tem sido defendida por diversos grupos de autores como uma alternativa viável no sentido de se padronizar o software de comunicação, utilizado em redes de computadores. Apesar disso, o que se observa é sua pequena utilização prática. Para justificar a não utilização do modelo tem-se entre outros, aspectos como adequação e eficiência, pois perde-se muita eficiência com a sobrecarga imposta por esse modelo, proveniente da comunicação entre suas sete camadas. Além 
disso o modelo ISO-OSI não dá suporte adequado ao mecanismo RPC. Alguns autores sugerem que o mecanismo de RPC deve ser implementado na camada de rede, enquanto outros consideram a camada de sessão a mais conveniente [TA89].

A característica de que o padrão OSI garante maior confiabilidade aos sistemas distribuídos é real, mas ressalta-se que tais sistemas têm como base redes locais, onde a freqüência de erros é muito baixa.

\subsection{Protocolo TCP/IP}

Um outro protocolo bastante utilizado é o TCP/IP, o qual corresponde a uma familia de protocolos desenvolvida pela DARPA (Defense Advanced Research Projects Agency) nos Estados Unidos para ser o protocolo base da Internet americana. Uma grande vantagem dos protocolos TCP/IP é que estes escondem detalhes de hardware e permitem que computadores se comuniquem independentemente de sua sub-rede de comunicação [CO91a].

A estrutura do protocolo TCP/IP está ilustrada na figura 3.3. Percebem-se pela estrutura do protocolo que as camadas enlace de dados e físicas são independentes da tecnologia de rede utilizada, podendo-se assim utilizar quaisquer padrões de rede.

\begin{tabular}{|c|c|}
\hline \multicolumn{2}{|c|}{ Aplicativos } \\
\hline TCP & UDP \\
\hline Internet (IP) \\
\hline $\begin{array}{c}\text { Interface de } \\
\text { Rede }\end{array}$ \\
\hline
\end{tabular}

Fig. 3.3 - Estrutura TCP/IP

É importante diferenciar os termos "internet" e "Internet". A palavra "internet" (com i minúsculo) refere-se a uma coleção de redes interconectadas por "gateways", que utilizam protocolos que viabilizam que as redes tenham logicamente a mesma função, como se fossem uma única rede. A palavra "Internet" (com i maiúsculo) refere-se especificamente ao conjunto de redes e gateways que utilizam os protocolos TCP/IP e funcionam como uma rede única e cooperativa. 
As camadas do protocolo podem oferecer dois tipos de serviços para as camadas superiores: orientados a conexão ou não orientados a conexão. $O$ aspecto essencial de uma comunicação orientada a conexão é que ela funciona como um tubo: o emissor coloca objetos em um lado e o receptor os pega no outro lado, na mesma ordem em que foram colocados.' É um serviço modelado em cima do sistema telefônico. O serviço não orientado a conexão é baseado no sistema postal. A mensagem possui o endereço destino completo, e cada uma delas é roteada pelo sistema independente das outras. A ordem de chegada pode ser diferente da ordem de emissão [TA89].

Além disso os serviços podem ser confiáveis ou não confiáveis. Geralmente os serviços confiáveis (no sentido de que nunca perdem algum dado) são implementados de maneira que o receptor sempre envia uma mensagem de reconhecimento ao receber cada mensagem, assim o emissor tem certeza de que a mensagem chegou. Nos serviços não confiáveis a mensagem tem grande probabilidade de chegar, porém não é fornecido mecanismo de reconhecimento para o emissor [TA89].

O protocolo IP ("Internet Protocol") define a unidade básica de transferência e o formato exato de todos os dados que passam pela Internet. Em adição à especificação formal dos formatos dos dados, o IP inclui um conjunto de regras que especificam como os processos devem ser executados e como os erros devem ser tratados. Esse protocolo define um mecanismo não confiável, não orientado a conexão para a transmissão dos dados.

O protocolo TCP ("Transmission Control Protocol") fornece um serviço confiável do qual dependem muitas aplicações. O TCP permite que um processo em uma máquina envie uma seqüência de dados a um outro processo em uma outra máquina; é orientado a conexão no sentido de que antes da transmissão dos dados ser iniciada, as partes envolvidas na comunicação devem necessariamente estabelecer uma conexão. $O$ software responsável pela implementação do TCP usualmente reside no sistema operacional e usa o protocolo IP para transmitir a informação pela Internet.

O protocolo UDP (User Datagram Protocol) fornece um serviço de liberação de informação não orientado a conexão e não confiável, isto é, não utiliza mecanismos para assegurar que a mensagem atingiu seu destino. As mensagens UDP podem ser perdidas, duplicadas ou desordenadas; além disso os pacotes podem chegar mais rápido do que o receptor pode processá-los. O UDP utiliza o IP para transportar as mensagens pelas máquinas.

Apesar da família de protocolos TCP/IP apresentar um número menor de camadas (quando comparada ao modelo ISO/OSI), ainda existe uma sobrecarga proveniente da comunicação entre as camadas, e mesmo assim é um dos protocolos mais utilizados atualmente [CO91a]. 


\subsection{O Modelo Cliente/Servidor}

Cliente(s) e servidor(es) juntamente com o sistema operacional e o sistema de comunicação entre processos, formam um sistema Cliente/Servidor, que permite computação distribuída. Em tais sistemas, um cliente é um processo que interage com 0 usuário e tem as seguintes características [SI92]:

a) Apresenta a interface para o usuário,

b) Comunica com o servidor via um mecanismo de comunicação entre processos e transmite as linhas de comando para o servidor,

c) Analisa os resultados recebidos do servidor e então os apresenta ao usuário.

Um servidor é um processo ou um conjunto de processos que devem existir em alguma máquina para fornecer serviços para o(s) cliente(s). Possui as seguintes características [S192]:

a) Um servidor fornece serviços para o cliente,

b) Um servidor apenas responde ao cliente; ele não inicia uma "conversa" com qualquer cliente,

c) Uma comunicação do cliente com o servidor pode ser feita sem o conhecimento da plataforma de software e hardware utilizada no servidor, assim como sem o conhecimento da tecnologia de software e hardware utilizada na comunicação.

Uma arquitetura Cliente/Servidor divide uma aplicação em processos separados, que podem estar operando em máquinas separadas, conectadas por uma rede, constituindo um sistema fracamente acoplado.

O modelo Cliente/Servidor representa uma alternativa natural para a implementação da comunicação em sistemas computacionais distribuídos, particularmente aqueles baseados em redes locais de computadores[TA85]. Se um cliente comunica com um servidor pela transmissão de uma mensagem, ele não precisa saber se a mensagem é endereçada localmente para sua própria máquina ou se ela será transmitida através de uma rede para um servidor em uma máquina remota (figura 3.4). $\mathrm{O}$ que o processo cliente necessita conhecer é a transmissão de uma mensagem e a recepção de uma resposta [TA85]. 


\begin{tabular}{|c|c|c|}
\hline CLIENTE & REDE & SERVIDOR \\
\hline $\begin{array}{c}\text { faz requisição } \\
\text { e espera resposta } \\
\cdot \\
\cdot \\
\cdot \\
\text { recebe resposta } \\
\text { e continua }\end{array}$ & $\begin{array}{c}\text { transmite requisição } \\
\cdot \\
\text { transmite resposta }\end{array}$ & $\begin{array}{l}\text { recebe requisição } \\
\text { executa } \\
\text { retorna resposta }\end{array}$ \\
\hline
\end{tabular}

Fig. 3.4 - Sequência de Comunicação Cliente-Servidor

\subsection{Tecnologias de Redes Locais}

Para se ter comunicação em redes locais, não é necessário que se tenha computadores dedicados para essa tarefa. Os computadores são conectados diretamente a um circuito de rede juntamente com interfaces de hardware. As interfaces de hardware e os programas de controle desses sub-sistemas, fazem com que os computadores possam transmitir e receber grande quantidade de dados com baixas taxas de erro.

O modelo de referência ISO/OSI, para redes locais, especifica uma família de padrões e a relação entre os seus membros. Nesse modelo estão padronizados os mecanismos de acesso ao meio, para 3 tecnologias diferentes de redes locais, referentes à camada 1 e 2 do modelo de referência [IE85a, IE85b,IE85c].

Esses padrões são:

1) ANSI/IEEE Std. 802.1 :- Constitui um documento descrevendo em detalhes a relação entre os padrões IEEE 802 e a arquitetura OSI.

2) ANSI/IEEE Std. 802.2 :- Especifica um protocolo de controle de acesso de enlace lógico para uso com qualquer um dos outros padrões referentes ao tipo de método de controle de acesso e meio de transmissão associado.

3) ANSI/IEEE Std. 802.3 :- Especifica um protocolo de acesso CSMA/CD num meio de transmissão configurado em barramento.

4) ANSI/IEEE Std. 802.4 :- Especifica, basicamente, um barramento com método de controle de acesso ao meio por "token".

5) ANSI/IEEE Std. 802.5 :- Especifica um anel com método de controle de acesso ao meio 
por "token".

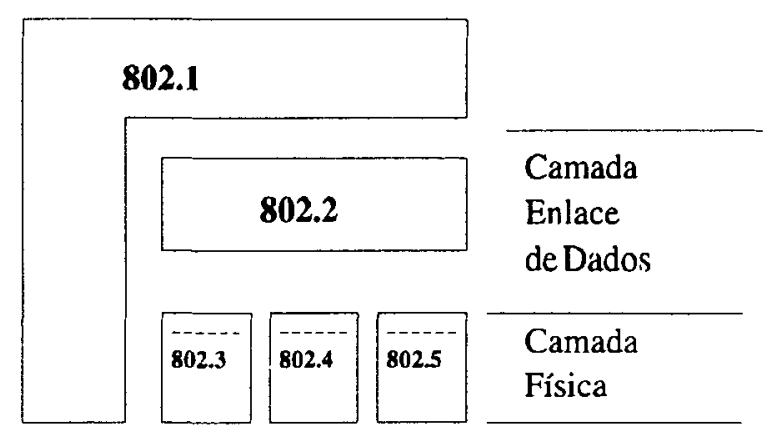

Fig. 3.5 - Família de Padrões para Redes locais

Nas próximas seções apresentam-se algumas tecnologias de rede existentes relevantes para este trabalho.

\subsubsection{Padrão IEEE 802.3 e ETHERNET}

A ETHERNET foi desenvolvida pela Xerox PARC em 1973. Devido ao seu sucesso, a Xerox, DEC e INTEL projetaram um padrão para a ETHERNET de $10 \mathrm{Mbps}$. Esse padrão formou a base para o padrão IEEE 802.3, o qual descreve toda a família de sistemas CSMA/CD 1- persistente, com taxa de transmissão que variam de 1 a $10 \mathrm{Mbps}$ em diversos meios [IE85a].

A ETHERNET é uma tecnologia de barramento por difusão, com controle de acesso distribuído. Um exemplo de configuração usual para redes locais baseadas nessa tecnologia é apresentado na figura 3.6.

Transceiver : lida com a detecção da portadora e de colisões. Quando uma colisão é detectada, o transceiver coloca um sinal inválido no cabo para assegurar que todos os outros transceivers detectem a ocorrência de colisão.

Cabo de interface: conecta o transceiver à placa de interface no computador. Pode ter um comprimento de no máximo $50 \mathrm{~m}$.

Controlador: responsável pela transmissão e recepção de "frames" do transceiver e para ele; agrupa os dados no formato do "frame" apropriado; faz a computação do CRC dos pacotes que saem e a verificação dos CRC dos pacotes que chegam. 
Ether: geralmente um cabo coaxial, cujo comprimento máximo é de $500 \mathrm{~m}$.

Repetidores: permitem que a rede se extenda fisicamente a distâncias maiores. $O$ repetidor recebe, amplifica e retransmite sinais em ambas as direções. Um sistema pode conter múltiplos segmentos de cabo e múltiplos repetidores, mas dois transceivers não podem estar separados por mais de $2.5 \mathrm{~km}$ e nenhum caminho entre dois transceivers pode atravessar mais que quatro repetidores.

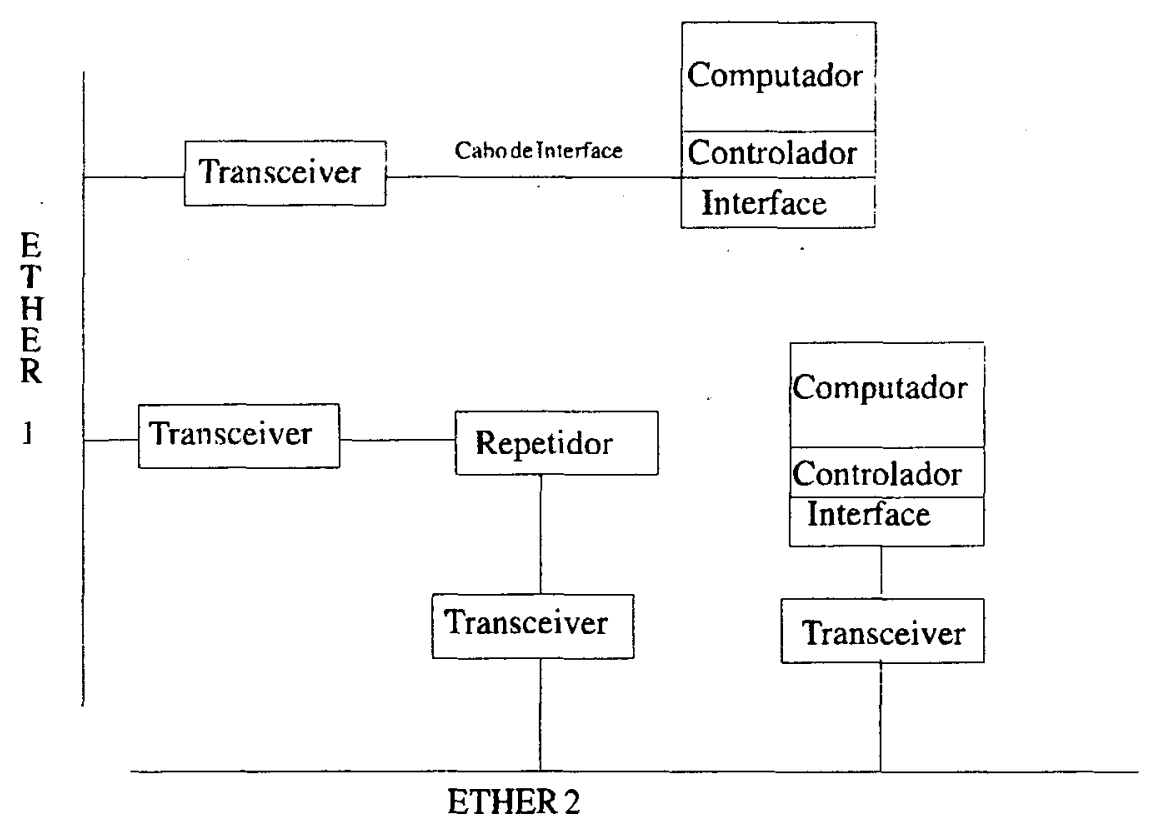

Fig. 3.6 - Configuração usual de uma Ethernet

\section{Formato do Pacote ETHERNET}

Os pacotes ETHERNET são de tamanho variável, tendo no máximo 1526 bytes e no mínimo 64 bytes. $O$ formato do pacote é mostrado na figura 3.7:

\begin{tabular}{|c|c|c|c|c|c|c|c|}
\hline$N^{\circ}$ de Bytes 7 & 1 & 6 & \multicolumn{2}{c}{6} & 2 & $0-1500$ & 46 \\
\hline Preâmbulo & Início & $\begin{array}{c}\text { Endereço } \\
\text { Destino }\end{array}$ & $\begin{array}{c}\text { Endereço } \\
\text { Origem }\end{array}$ & Tam. & Dados & PAD & CRC \\
\hline
\end{tabular}

Fig. 3.7 - Formato do Pacote Ethernet 
* Preâmbulo: Seqüência de bits utilizada para sincronização.

* Início: Denota o início do "frame".

* Endereço Destino: Endereço destino do pacote.

* Endereço Origem: Endereço do emissor do pacote.

* Tam: Indica quantos bytes existem no campo de dados.

* Dados: Contém a mensagem a ser enviada, ou em parte dela (se o total exceder os 1500 bytes).

* PAD: É utilizado para sempre preencher o "frame" com um tamanho mínimo.

* CRC: Auxilia na deteç̧ão de erros. O emissor calcula o CRC na transmissão e o receptor o calcula novamente verificando se são iguais.

\subsubsection{Padrão IEEE 802.4: Token BuS}

O padrão IEEE 802.4 [IE85b] consiste na interconexão lógica das estações na forma de anel, embora a estrutura de conexão física siga a topologia de barramento. A cada estação é assinalada uma posição numa ordem seqüencial, com o último membro da seqüência seguida pelo primeiro. Cada estação conhece a identidade da estação sucessora e predecessora (figura 3.8).

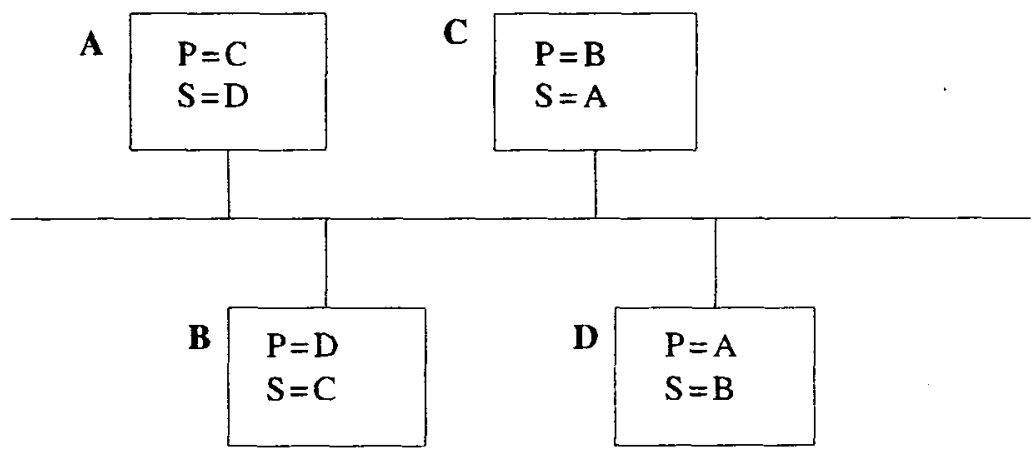

Fig. 3.8 - Token Bus

Fisicamente o Token Bus adota um cabo coaxial utilizado em comunicações de TV via cabo, e pode ter velocidade de transmissão de 1,5 , e $10 \mathrm{Mbps}$. 


\section{Formato do Pacote Token Bus}

\begin{tabular}{|c|c|c|c|c|c|c|c|}
\hline $\mathrm{N}^{\circ}$ de Bytes & 1 & 1 & 2 ou 6 & 2 ou 6 & $0-$ & & \\
\hline$P$ & SD & FC & $\begin{array}{c}\text { Endereço } \\
\text { Destino }\end{array}$ & $\begin{array}{c}\text { Endereço } \\
\text { Origem }\end{array}$ & Dados & CRC & ED \\
\hline
\end{tabular}

Fig. 3.9 - Formato do Pacote Token Bus

* Preâmbulo (P): Utilizado para sincronizar o clock do receptor;

* Start Delimiter (SD) e End Delimiter (ED): Marcam o início e o fim do pacote respectivamente. Ambos os campos contém codificações analógicas de símbolos diferentes de $0 \mathrm{~s}$ e $1 \mathrm{~s}$, de tal forma que não ocorram acidentalmente nos dados;

* Frame Control (FC): Diferencia pacotes de dados dos pacotes de controle. No caso dos pacotes de dados, o campo traz a prioridade do pacote. Pode também carregar um indicador pedindo à estação destino que faça um reconhecimento da recepção correta ou incorreta do pacote.

Para pacotes de controle, o campo é utilizado para indicar o tipo do "frame". Os tipos permitidos incluem passagem do "token" e vários pacotes de manutenção do anel, incluindo mecanismos que permitam a inclusão de novas estações ao anel, liberação de estações, etc;

* Endereço Destino: Endereço do destinatário do pacote;

* Endereço Origem: Endereço do emissor do pacote;

* Dados: contém a mensagem a ser enviada, total ou em partes;

* CRC: auxilia na deteç̧ão de erros de transmissão.

\subsubsection{Padrão IEEE 802.5: Token Ring}

Token Ring é provavelmente a técnica mais antiga de controle de acesso ao meio em redes configuradas em anel. Tornou-se bastante popular nos Estados Unidos, tendo sido utilizada em vários produtos comerciais - a Prime Computer e a Apollo comercializaram produtos Token Ring, e a IBM adotou-a como base para seus produtos de sistemas distribuídos. A IEEE 802 selecionou-a para padronização tornando-se 0 padrão 802.5 [IE85c]. 

a ponto.

O anel consiste de uma coleção de interfaces de anel conectadas por linhas ponto

Cada bit que chega em uma interface é copiado em um buffer de 1 bit, e em seguida é copiado para o anel novamente. Enquanto está no buffer, o bit pode ser inspecionado e possivelmente modificado antes de ser passado para o anel. $O$ período de cópia introduz um atraso de 1 bit em cada interface.

Uma implicação importante no projeto da Token Ring é a capacidade do anel acomodar o token completo quando todas as estações estão desocupadas. Isso é assegurado através da introdução do atraso de 1 bit por cada estação, mais o atraso de propagação do sinal.

Como na Token Bus, a Token Ring tem a vantagem de possuir esquema de prioridades, o que garante uma adequação a aplicações de tempo real.

Formato do Pacote e Token da Token Ring

\begin{tabular}{|l|l|l|}
\hline bytes 1 & \multicolumn{1}{c}{1} \\
\hline SD & AC & ED \\
\hline
\end{tabular}

a)

\begin{tabular}{c|c|c|c|c|c|c|c|c|c|}
$\mathrm{N}^{\circ}$ de Byte & 1 & 1 & \multicolumn{1}{c}{ sem } \\
\cline { 2 - 8 } & SD & AC & FC & $\begin{array}{c}\text { Endereço } \\
\text { Destino }\end{array}$ & $\begin{array}{c}\text { Endereço } \\
\text { Origem }\end{array}$ & Dados & CRC & ED & FS \\
\hline
\end{tabular}

b)

Fig. 3.10 - a) Formato do Token

b) Formato do Pacote Token Ring

* Start Delimiter (SD) e End Delimiter (ED): Marcam o início e o fim do pacote. São codificados de forma a se diferenciarem dos dados;

* Access control (AC): Indica se o "token" está livre ou ocupado, identifica a prioridade 
do pacote que está sendo transmitido, e a reserva do próximo frame livre com uma dada prioridade;

* Frame Control (FC): Diferencia pacotes de dados dos pacotes de controle;

* Endereço Destino: Endereço do destino do pacote;

* Endereço Origem: Endereço do emissor do pacote;

* Dados: Contém a mensagem a ser enviada, total ou em partes;

* CRC: auxilia na deteç̧ão de erros.

* Frame Status (FS): contém os bits de sinalização A e C.

\subsubsection{Cambridge Ring}

$\mathrm{O}$ anel de Cambridge foi projetado com o objetivo de permitir alta velocidade e comunicação com pequena taxa de erros entre computadores e outros dispositivos. As finalidades iniciais eram o compartilhamento de recursos e a transferência de arquivos.

O primeiro protótipo da Cambridge Ring (CR) data de 1975 no Laboratório de Computação da Universidade de Cambridge e foi o precursor de projetos futuros desenvolvidos em Cambridge [HO80].

$\mathrm{Na}$ Cambridge Ring a informação é enviada em pequenos pacotes de tamanho fixo denominados minipackets. Um minipacket contém: 8 bits de endereço origem, 16 bits de dados e alguns bits de controle. Os bits de controle são : o SOP ("Start of Minipacket"), o qual indica o início do pacote assumindo sempre o valor 1; o "full/empty" (FE) que indica se o minipacket está sendo usado ou não; o "monitor-passed" (MP) responsável por auxiliar na deteç̧ão de erros pela estação monitora; os dois bits de resposta que assumem os valores 1 quando o minipacket é transmitido e são modificados pela estação destino com o objetivo de refletir o estado da recepção; e finalmente, o bit de paridade usado na deteç̧ão de erros no sistema de transmissão. O minipacket da Cambridge Ring está ilustrado na figura 3.11.

\begin{tabular}{|c|c|c|c|c|c|c|c|c|c|}
\hline 1 & FE & MP & $\begin{array}{c}\text { Endereço } \\
\text { Destino }\end{array}$ & $\begin{array}{c}\text { Endereço } \\
\text { Origem }\end{array}$ & Dado & Dado & Resp & Resp & $\begin{array}{c}\text { Pari- } \\
\text { dade }\end{array}$ \\
\hline
\end{tabular}

Fig 3.11 - O "mini packet" da Cambridge Ring 


\subsubsection{Cambridge Fast Ring}

A Cambridge Fast Ring (CFR) foi projetada com o objetivo principal de ser mais rápida que as redes disponiveis até então. Dessa forma, consideraram-se todas as redes disponíveis sendo escolhida a Cambridge Ring por dois motivos principais: o primeiro devido à experiência adquirida no projeto da Cambridge Ring e o segundo, devido ao fato da estrutura de "slotted rings" possuir certas propriedades sugestivas a uma rede de alta velocidade; dentre as quais pode-se citar a possibilidade da existência de vários "slots" no anel simultaneamente. Assim os "slots" podem ser marcados e conseqüentemente diferenciados uns dos outros, o que permite a elaboração de esquemas de alocação de "bandwidth". Assim, os "hosts" podem ter estratégias de transmissão diferentes, ou seja, um "host" que transmite voz pode alocar "bandwidth" para isso enquanto outro que transmite imagens aloca "bandwidth" para imagens.

Também foram considerados no projeto o custo da implementação e conexão, além da confiabilidade da rede.

\subsubsection{FDDI (Fiber Distributed Data Interface)}

A FDDI é uma rede Token Ring de fibra ótica com alto desempenho, atingindo 100 Mbps com até 1000 estações conectadas.

Embora possa ser utilizada do mesmo modo que as tecnologias de rede 802.3, 802.4 e 802.5, é na maioria das vezes utilizada como "backbone" para conectar redes de cabo coaxial ou par trançado devido à sua alta capacidade de transmissão. Possui uma taxa de erros muito baixa, da ordem de um erro a cada $2,5 \times 10^{10}$ bits.

O meio fisico da FDDI é formado por dois anéis de fibra ótica, um transmitindo no sentido horário e o outro transmitindo no sentido anti-horário. Se um deles quebra, o outro pode ser usado. Se ambos quebram no mesmo ponto, por exemplo, devido a um acidente no duto, os dois anéis podem ser juntados em um único anel com aproximadamente o dobro de comprimento. Cada estação contém reles que podem ser usados para juntar os dois anéis ou isolar as estações com problemas.

\subsection{Considerações Finais}

Os protocolos de comunicação são de vital importância no contexto de sistemas distribuídos, regendo a comunicação entre os processos clientes e processos servidores. 
As arquiteturas das redes de computadores são comumente dispostas em camadas hierárquicas, com o objetivo de abstrair para cada camada um conjunto mínimo de funções, com a intenção de assim diminuir a sua complexidade. Na comunicação entre máquinas há uma comunicação virtual entre as camadas correspondentes.

As tecnologias possuem desempenho similares, sendo que as redes em anel possuem uma utilização melhor do canal a altas cargas, e a ETHERNET possui um desempenho melhor a baixas cargas.

No próximo capítulo apresentam-se técnicas de comunicação entre processos. O mecanismo de RPC é apresentado em detalhes. 


\section{Capítulo 4}

\section{Troca de Mensagens}

A comunicação entre processos pode ser subdividida em duas categorias gerais: dados compartilhados e troca de mensagens - embora essa caracterização não seja sempre tão clara [TA85]. Muitos fatores devem ser considerados quando se envia uma mensagem, por exemplo quem a envia; o que é enviado; para quem é enviada; se é garantido ou não que ela chegou no computador remoto; se é garantido ou não que o processo remoto a recebeu; se existe alguma resposta (ou várias); o que acontece se algo der errado, e outros. Existem também vários fatores a serem considerados na recepção de uma mensagem: para qual processo ou processos no computador a mensagem foi destinada; deverá ser criado um processo para gerenciar essa mensagem; se a mensagem foi destinada para um processo existente, o que fazer se esse processo estiver ocupado - a mensagem é colocada numa fila ou é descartada - e se o processo receptor estiver com mais mensagens na fila, ele pode ou não escolher a ordem de atendimento das mensagens - seja por FIFO, pelo emissor, por algum tipo ou identificador da mensagem, pelo conteúdo da mensagem ou de acordo com o estado interno do processo receptor.

Os computadores que formam um sistema distribuído normalmente não compartilham memória primária, assim técnicas de comunicação através de compartilhamento de memória geralmente não são aplicadas. Uma das formas de comunicação que pode ser aplicada é a troca de mensagens [TA85].

Os mecanismos de comunicação e sincronização, em sistemas de memória distribuída, baseiam-se na troca de mensagens entre processos realizada por primitivas simples do tipo "envia", "recebe" e suas variações. Os mecanismos síncronos apresentam maior interesse e são constituídos por: rendez-vous, rendez-vous estendido e chamada a procedimentos remotos [KI89].

O bom desempenho dos sistemas de chamada a procedimentos remotos é importante para que as aplicações distribuídas tenham bom desempenho. É também importante o desempenho local, quando são utilizadas chamadas remotas para se obter serviços de outros programas na mesma máquina.

Chamadas a procedimentos remotos demoram mais tempo para serem executadas devido à sobrecarga causada na comunicação e aos efeitos do escalonamento dos processos [RO85]. 
Este capitulo apresenta noções sobre esses mecanismos de comunicação e sincronização, dando maior ênfase ao mecanismo baseado em "Chamadas a Procedimentos Remotos" (Remote Procedure Calls - RPC). Ainda serão discutidos aspectos sobre o desempenho dos protocolos e dos mecanismos de comunicação. É dada ênfase no desempenho das chamadas a procedimentos remotos.

\subsection{Mecanismos para Troca de Mensagens}

O modelo mais utilizado pelos pesquisadores nessa área é o cliente-servidor, segundo o qual um processo cliente que deseja algum serviço, envia uma mensagem para o servidor e espera pela resposta. Na sua forma mais simples o sistema possui apenas duas primitivas: $S E N D$ e RECEIVE. A primitiva $S E N D$ especifica o destino e fornece a mensagem, a primitiva $R E C E I V E$ informa de quem se espera uma mensagem (inclusive "ninguém") e fornece um buffer onde a mensagem será armazenada. Não é necessário setup inicial, e nenhuma conexão é estabelecida [TA85].

Precisamente quais semânticas essas primitivas devem ter, tem sido motivo de muita controvérsia entre pesquisadores. Duas decisões fundamentais devem ser feitas: a escolha da utilização de primitivas confiáveis ou não e primitivas bloqueantes ou nãobloqueantes. De um lado a primitiva $S E N D$ pode colocar uma mensagem na rede e apenas desejá-la boa sorte. Não se fornece garantia de transmissão, e se o sistema perde a mensagem não é feita a retransmissão automática. Por outro lado, a primitiva $S E N D$ pode gerenciar mensagens perdidas, retransmissões, de tal maneira que quando a primitiva terminar a sua execução o programa terá a certeza de que a mensagem foi recebida e confirmada [TA85].

A outra escolha a ser feita é entre primitivas bloqueantes e não-bloqueantes. Com primitivas não-bloqueantes, a primitiva $S E N D$ retorna o controle ao programa do usuário assim que a mensagem foi colocada na fila para transmissão. Quando a mensagem for transmitida, o programa é interrompido para informar que o buffer pode ser reutilizado. A primitiva RECEIVE correspondente sinaliza a disponibilidade de receber uma mensagem e fornecer um buffer para colocar a mensagem recebida. Quando a mensagem chega o programa é avisado por interrupção, ou pode ser colocado em espera (SLEEP) até ocorrer a interrupção. A vantagem das primitivas não-bloqueantes é que elas fornecem uma flexibilidade máxima: programas podem executar cálculos e mensagens de $\mathrm{V} / \mathrm{O} \mathrm{em}$ paralelo, da maneira que for necessário.

Por outro lado, primitivas não-bloqueantes têm uma desvantagem: elas tornam a programação mais complexa. Programas dependentes do tempo são penosos para se escrever e dificeis de se depurar. Como conseqüência várias pessoas preferem sacrificar 
um pouco a flexibilidade e eficiência e utilizar primitivas bloqueantes. Uma primitiva $S E N D$ bloqueante não retorna o controle para o usuário até que a mensagem tenha sido enviada (primitiva bloqueante não confiável) ou até que a mensagem tenha sido enviada e seu recebimento confirmado (primitiva bloqueante confiável). De qualquer maneira, o programa pode modificar o buffer sem perigo. Uma primitiva RECEIVE bloqueante não retorna o controle até que uma mensagem tenha sido colocada no buffer. As primitivas RECEIVE confiáveis e não confiáveis se diferem no ponto que as primeiras enviam um reconhecimento automático acusando o recebimento da mensagem, o que não acontece com as não confiáveis. Não é coerente combinar uma primitiva $S E N D$ confiável com uma primitiva $R E C E I V E$ não confiável ou vice-versa. Primitivas bloqueantes e não bloqueantes não são conflitantes, assim não tem problema se o emissor utilizar uma e o receptor outra [TA85].

Uma outra decisão que deve ser tomada é se as mensagens serão armazenadas ou não. A estratégia mais simples é não armazená-las. Quando um emissor tem uma mensagem para um receptor que aindá não executou a primitiva $R E C E I V E$, o emissor é bloqueado até que a primitiva $R E C E I V E$ seja executada, e nesse momento a mensagem é copiada do emissor para o receptor (rendezvous).

Uma pequena variação desse esquema é copiar a mensagem para um buffer interno na máquina do emissor, fornecendo assim uma versão não bloqueante do mesmo esquema.

Uma solução mais geral é se ter um mecanismo de armazenamento, freqüentemente no kernel do sistema operacional, que permite aos emissores executarem múltiplas primitivas $S E N D$, mesmo sem qualquer interesse no receptor.

O próximo passo em sistemas de troca de mensagens é fazer com que o modelo "o cliente envia uma requisição e é bloqueado até que o servidor envie uma resposta" - se pareça com uma chamada a um procedimento tradicional do cliente para o servidor. Esse modelo ficou conhecido como RPC - "Remote Procedure Call" (Chamada a Procedimento Remoto). A idéia é fazer a semântica da comunicação entre as máquinas o mais parecida possivel com as chamadas a procedimentos normais, pois essas são familiares, bem entendidas e têm se mostrados uma ferramenta útil e adequada para se tratar com abstração. Na seção 4.2 serão apresentados maiores detalhes sobre RPC[TA85].

\subsubsection{Rendez-vous}

O rendez-vous, mecanismo também conhecido como comunicação ponto a ponto, é obtido através de primitivas envia e recebe bloqueantes, colocadas em dois processos distintos, referenciando-se mutuamente (figura 4.1). A execução dessas primitivas em 
tempos diferentes fará com que o processo que executar a primitiva em primeiro lugar, fique bloqueado até que ocorra a sincronização entre os dois processos. Depois da sincronização, ocorrerá a transferência da mensagem e os dois processos continuarão seu andamento normal em paralelo [KI89].

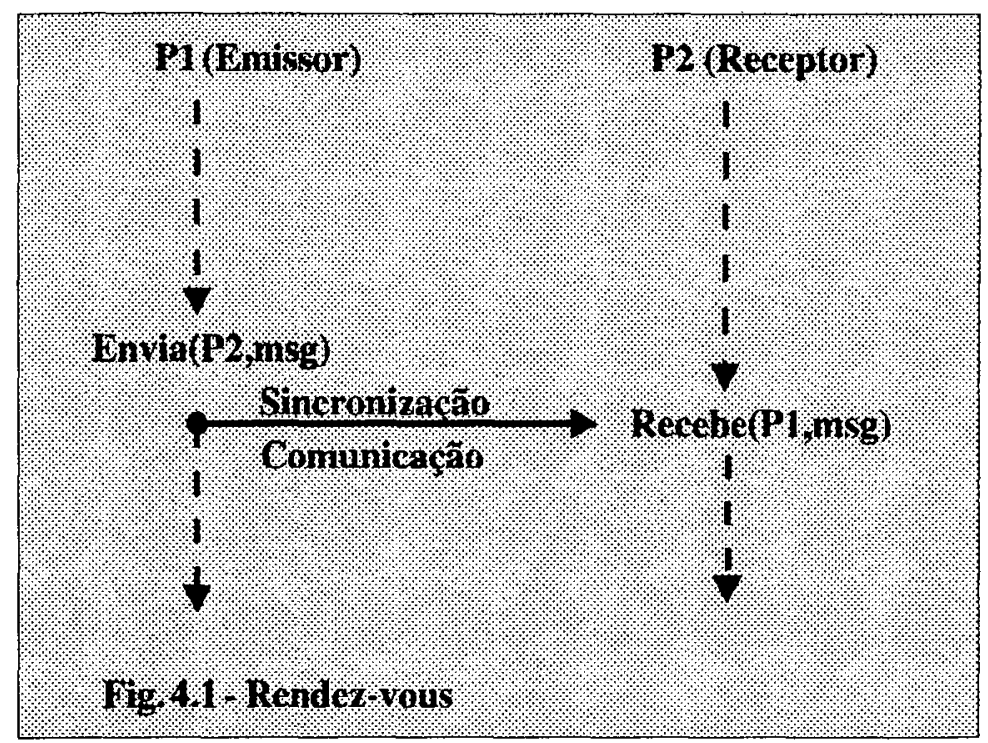

\subsubsection{Rendez-vous Estendido}

O rendez-vous estendido, também referenciado na literatura simplesmente como rendez-vous, apresenta uma estrutura de comunicação, onde um processo consegue comandar a execução de um trecho de programa previamente estabelecido pertencente a outro processo. O processo requisitante, ao realizar a chamada de um ponto de entrada de outro processo, ficará bloqueado enquanto não receber uma resposta de término desse trecho. A chamada deve ser sincronizada com o ponto de entrada do trecho de programa do outro processo, de forma que qualquer deles, que atingir seu ponto de sincronização em primeiro lugar, ficará à espera do outro. Depois de sincronizado, o processo receptor executará o trecho de programa que, ao terminar, será novamente sincronizado com seu parceiro, indicando o término do rendez-vous estendido e permitindo que a execução dos dois processos possa transcorrer em paralelo (figura 4.2). 


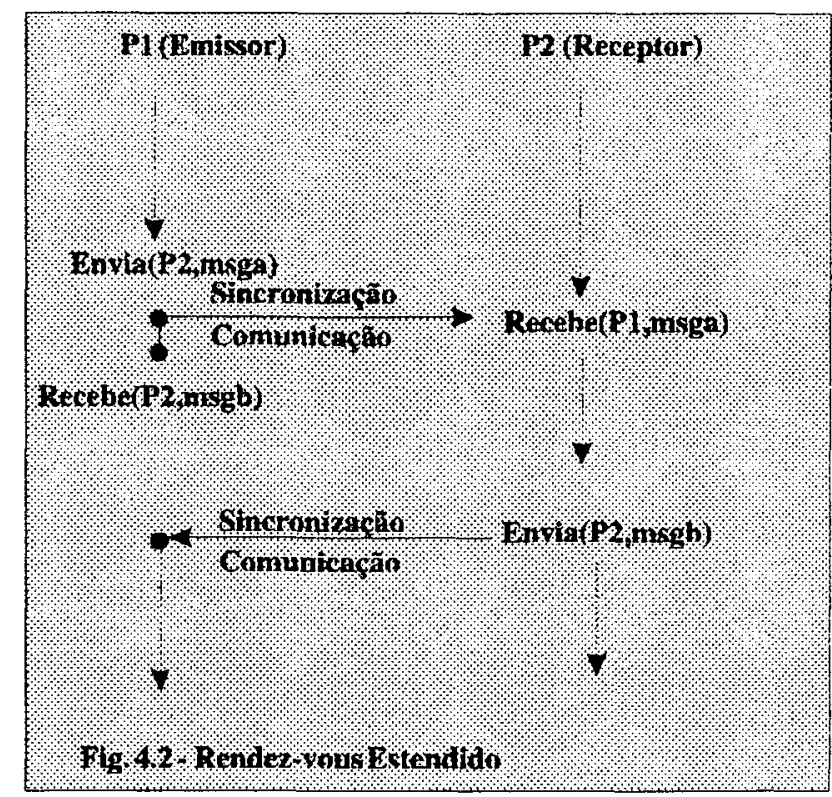

\subsection{Chamada a Procedimentos Remotos (RPC)}

A idéia do mecanismo RPC é bem simples. Ela é motivada pelo fato de o mecanismo de chamada a procedimentos locais (para transferir controle e dados em um programa) ser bem conhecido e entendido. Daí propôs-se que esse mesmo mecanismo fosse estendido para que se pudesse transferir controle e dados através de uma rede de comunicação. Quando se chama uma rotina remota, o ambiente do cliente é suspenso, os parâmetros são passados através da rede para o ambiente onde o procedimento será executado, e então esse procedimento chamado será executado. Quando o procedimento termina e produz seus resultados, eles são passados de volta para o ambiente que solicitou o procedimento, onde a execução termina como se fosse um retorno de uma chamada a um procedimento local.

Vários aspectos são atrativos nessa idéia. Primeiro, a semântica é clara e simples, o que facilita a construção e a depuração de sistemas distribuídos. Um outro aspecto é a eficiência: as chamadas parecem ser simples o suficiente para se ter uma comunicação rápida. Um terceiro aspecto é a generalidade: em sistemas que são executados em uma única máquina, chamada a procedimentos é geralmente o mecanismo mais utilizado para a comunicação entre partes de um algoritmo [BI84]. 


\subsubsection{Aspectos de Projeto}

Existem alguns pontos que devem ser cuidadosamente observados no projeto de um sistema RPC [MU89]:

- "Binding": Como o programa cliente nomeia o procedimento a ser chamado e como ele encontra esse procedimento.

Um sistema RPC deve fornecer mecanismos para se conectar o programa cliente e o procedimento que está sendo chamado. $O$ programa cliente tem um nome para $o$ procedimento e a esse nome deve ser associado a um valor real. Além do mais, é importante se certificar de que o cliente e o procedimento chamado concordam na interface. Abstratamente, a situação para chamadas remotas é idêntica à situação para chamadas locais.

- "Heterogeneidade": Como o sistema lida com máquinas de tipos diferentes e com programas escritos em diferentes linguagens de programação.

Sistemas distribuidos exibem um alto grau de heterogeneidade: diferentes tipos de máquinas são interligadas na mesma rede de comunicação e os programas que estão sendo executados nessas máquinas geralmente são escritos em diferentes linguagens. Um importante objetivo a se atingir é permitir que programas executados nesse ambiente heterogêneo possam se comunicar. Para que isso seja possível, é necessário definir uma semântica de comunicação de forma que ela seja independente da linguagem e da máquina.

Se os tipos usados nas mensagens são diferentes dos tipos usados localmente nos programas, precisa-se de uma maneira de convertê-los entre os dois tipos. Mesmo se forem do mesmo tipo, pode ser utilizada uma representação diferente para o mesmo tipo e uma forma de conversão é necessária aqui também. Muitos sistemas RPC utilizam os stubs (às vezes gerados automaticamente) para realizar essas conversões. Stubs são descritos no item 4.2.4. 
- "Transparência": Quão similar é a semântica de uma chamada remota comparada com uma chamada local.

Um objetivo básico de muitos sistemas RPC é fazer a semântica da chamada remota o mais parecida possível com uma chamada local, embora algumas diferenças sejam quase impossiveis de se evitar.

Em primeiro lugar, a possibilidade de falha na comunicação afeta a semântica das chamadas remotas. Os sistemas tratam dessas falhas de diferentes maneiras. A invocação de um procedimento pode resultar em zero, uma ou mais chamadas ao procedimento, cada uma resultando na execução completa ou não do mesmo. Essas semânticas fazem com que o tratamento dessas falhas seja feito na aplicação. No item 4.2.3 são descritas as semânticas de chamadas a procedimentos.

Um outro ponto a ser considerado, onde a transparência é difícil de ser alcançada, é na passagem de parâmetros. Por isso alguns sistemas RPC restringem o conjunto de dados que podem ser utilizados em procedimentos remotos e a maioria dos sistemas RPC passam argumentos e resultados por valor.

- "Concorrência": Quais mecanismos são oferecidos para se obter concorrência e como eles interagem com o mecanismo de comunicação.

Em muitos sistemas RPC uma chamada remota é bloqueante: o programa cliente é suspenso até que o procedimento chamado retorne um resultado.

A facilidade de processos lightweight [BE89] fornece solução para alguns dos problemas causados pelas chamadas bloqueantes. Um servidor pode executar chamadas de vários clientes concorrentemente, cada uma em processos separados. Similarmente um cliente pode criar vários processos para se trabalhar concorrentemente; se um é bloqueado (provavelmente esperando pelo retorno de uma chamada remota), os outros podem continuar sua execução.

\subsubsection{O Mecanismo RPC}

RPC é um mecanismo que fornece comunicação síncrona e segura entre dois processos. É um caso especial do modelo geral de troca de mensagens de comunicação entre processos (IPC) [WI87]. No caso mais simples, IPC baseado em mensagens envolve um processo (cliente) enviando uma mensagem para outro (servidor). Não é necessário 
que eles estejam sincronizados. Entretanto, o mecanismo RPC impõe que os processos estejam sincronizados, pois como já foi visto, a maior parte das chamadas a procedimentos remotos são bloqueantes.

O mecanismo RPC é freqüentemente implementado da seguinte maneira:

As duas partes da aplicação são divididas através de uma fronteira procedural e de um procedimento falso com o mesmo nome no servidor e no cliente. Esse procedimento falso, geralmente conhecido como stub, é responsável por pegar os parâmetros da chamada, colocá-los num formato adequado para a transferência antes de enviá-los para o servidor. Ele então espera pela resposta do servidor, desempacota os resultados antes de convertê-los para a representação local e os passa para o procedimento que fez a chamada.

No servidor a situação é similar, só que o servidor pode atender vários tipos de chamadas. O programa principal do servidor espera por uma mensagem, decide qual procedimento chamar, reformata os parâmetros para representação local e então chama o procedimento. Quando este terminar, os resultados são empacotados e transmitidos de volta para o cliente. Percebe-se que só existe uma linha de controle no programa de aplicação, embora existam duas máquinas e processos no sistema. Ainda pode-se notar que se assume que o cliente e o servidor estão em diferentes espaços de endereço, então todos os parâmetros devem ser passados por valor [WI87].

Trata-se de um mecanismo de comunicação simples e de fácil implementação. No caso de RPC, a idéia básica é permitir um programa chamar procedimentos em computadores diferentes ou em processos mapeados em áreas diferentes de memória, dentro de uma mesma máquina, e de uma forma transparente do ponto de vista do usuário. A transparência ideal é conseguida quando o usuário tem a ilusão de estar executando uma chamada de procedimento local.

\subsubsection{Semântica de Chamada}

Devido ao ambiente em que é utilizado o mecanismo RPC, normalmente constituído por computadores diferentes, há a necessidade de tratamento de dois grandes problemas: perda de mensagens e quebra de computadores (cliente ou servidor). Uma chamada a um procedimento remoto pode não ter sucesso, caso o cliente, o servidor ou o meio de comunicação entre eles venha a falhar. Falhas temporárias podem ser contornadas pela repetição dos procedimentos, normalmente associadas a mecanismos de temporização ("time out"). Quatro casos básicos são possíveis [WI87], conforme pode ser observado na figura 4.3 . 


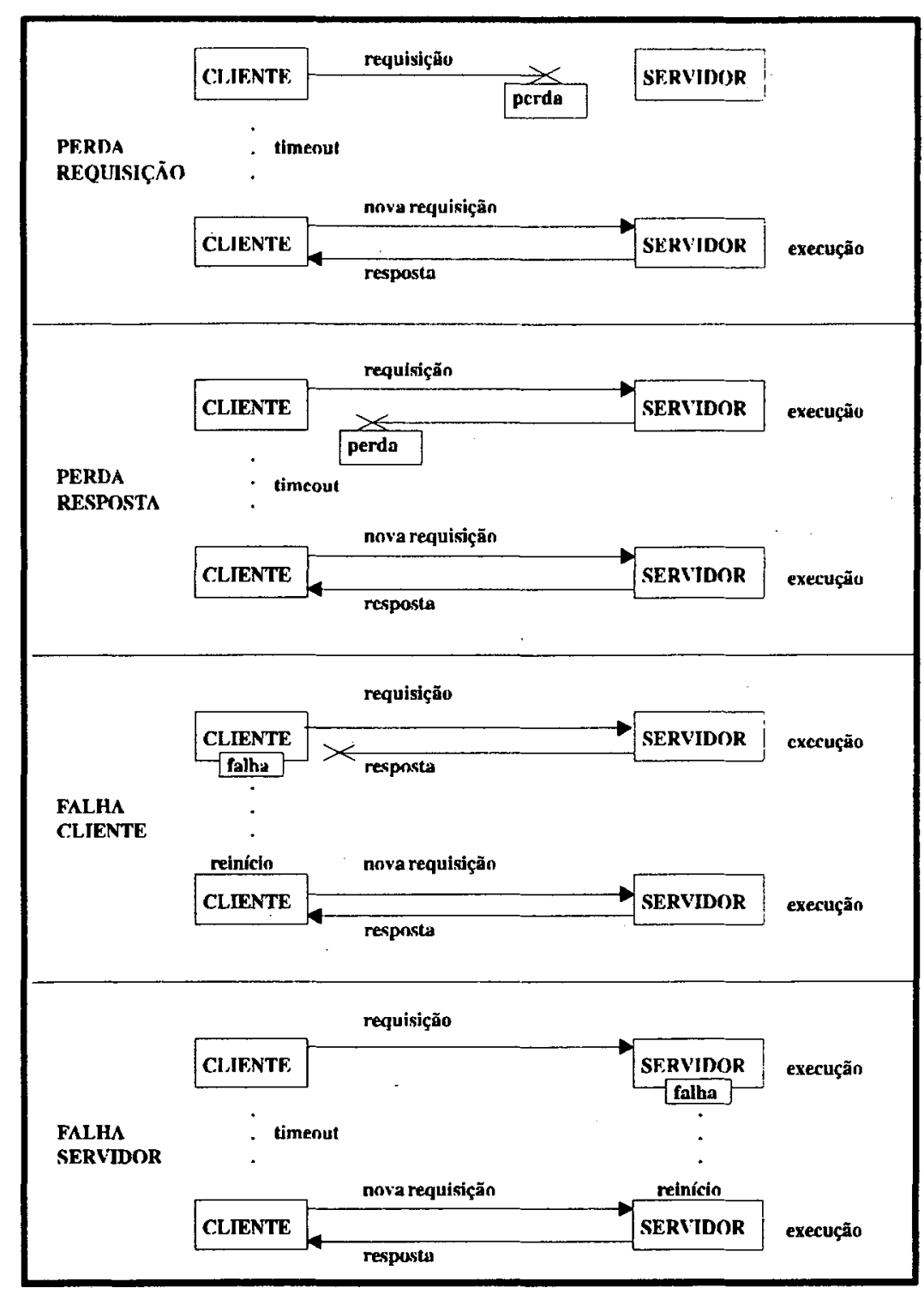

Fig. 4.3 - Tratamento de falhas em RPCs

A semântica de chamada determina a freqüência com que a função remota deve ser executada. As quatro possibilidades descritas a seguir encontram-se em ordem crescente de rigidez:

> Possivelmente uma execução - A requisição é feita assumindo-se que ela será atendida. Esse modo não atende aos requisitos do mecanismo RPC.

$>$ Pelo menos uma execução - Repete-se a requisição até que uma resposta seja recebida. É possível, no caso de perda da resposta, que a primitiva seja executada mais de uma vez. É importante que a primitiva tenha resposta e efeito idênticos, no caso de uma ou várias execuções. 
$>$ No máximo uma execução - O servidor controla as requisições dos clientes de tal forma que uma primitiva não seja executada mais que uma vez. Uma requisição repetida, motivada pela perda da resposta, ocasiona a retransmissão da última resposta calculada.

$>$ Exatamente uma execução - Nesse caso garante-se a execução da primitiva uma única vez. É importante dispor de informações armazenadas em dispositivos não voláteis e múltiplos recursos para contornar falhas no hardware.

$\mathrm{Na}$ comunicação cliente/servidor, existe a necessidade de conhecimentos sobre os endereços dos processos envolvidos e que estão se comunicando, muitas vezes em computadores diferentes através da rede. Mais especificamente, o cliente deve obter o endereço do servidor. Essa obtenção pode ser de formas diferentes e aplicáveis em diferentes situações. Pesquisa em tabela ou arquivo, solicitação a um operador ou mesmo consulta a servidores de nome são op̧̧ões possiveis.

\subsubsection{Representação de Dados}

A heterogeneidade dos Sistemas Distribuídos (sistemas operacionais diferentes e computadores incompativeis), faz com que surja uma preocupação em relação às diferentes representações dos diversos tipos de dados. Devido à necessidade de comunicação entre os vários componentes do sistema é inevitável que se tente resolver esse problema. A solução é fazer conversão de tipos, certamente nos stubs para manter a transparência. A conversão pode ser feita no cliente ou no servidor e a escolha sempre recai sobre o que resultar em um número menor de conversões.

Mais problemas são encontrados quando há necessidade de passagem de parâmetros para os procedimentos remotos. Em chamadas locais tem-se passagem de parâmetros por valor e por referência. Por referência, são passados os endereços dos parâmetros e não o seu valor. Como nos Sistemas Distribuídos, o espaço de endereçamento do processo cliente é diferente do processo servidor não faz sentido a passagem de endereços.

A passagem e o retorno de valores de um procedimento remoto devem ser sempre por valor, isto é, os parâmetros e resultados são copiados no servidor e no cliente.

O uso de cadeias muito longas ou multi dimensionais como parâmetros acarretam problemas com o tempo de transmissão pela rede. Isso impõe restrições de tamanhos e tipos dos parâmetros que podem ser passados. 


\subsubsection{Stubs e Interfaces}

A função dos stubs do cliente e do servidor é manipular os dados contidos numa mensagem enviada ou numa resposta recebida de modo que esses dados possam ser transmitidos pela rede ou possam ser utilizados pelo processo receptor [WI87]. Assim pode-se manter uma transparência aparente para os processos cliente e servidor, sem diferenças entre procedimentos locais e RPC. A figura 4.4 ilustra a comunicação através do mecanismo RPC utilizando-se processos stubs.

Os stubs conseguem uma transparência relativa da seguinte maneira: quando um processo cliente deseja fazer uma chamada remota, ele faz uma chamada local normal para um processo stub no mesmo computador (client stub). O client stub monta a mensagem a ser enviada para o server stub, colocando o endereço do processo servidor e os parâmetros. O server_stub recupera as mensagens transmitidas pela rede e desempacota os parâmetros fazendo depois uma chamada local ao procedimento especificado. Quando o procedimento termina sua execução, passa o controle novamente para o server_stub e esse retorna os resultados empacotados em uma mensagem para o client_stub que, por sua vez, desempacota-os e os passa para o processo cliente.

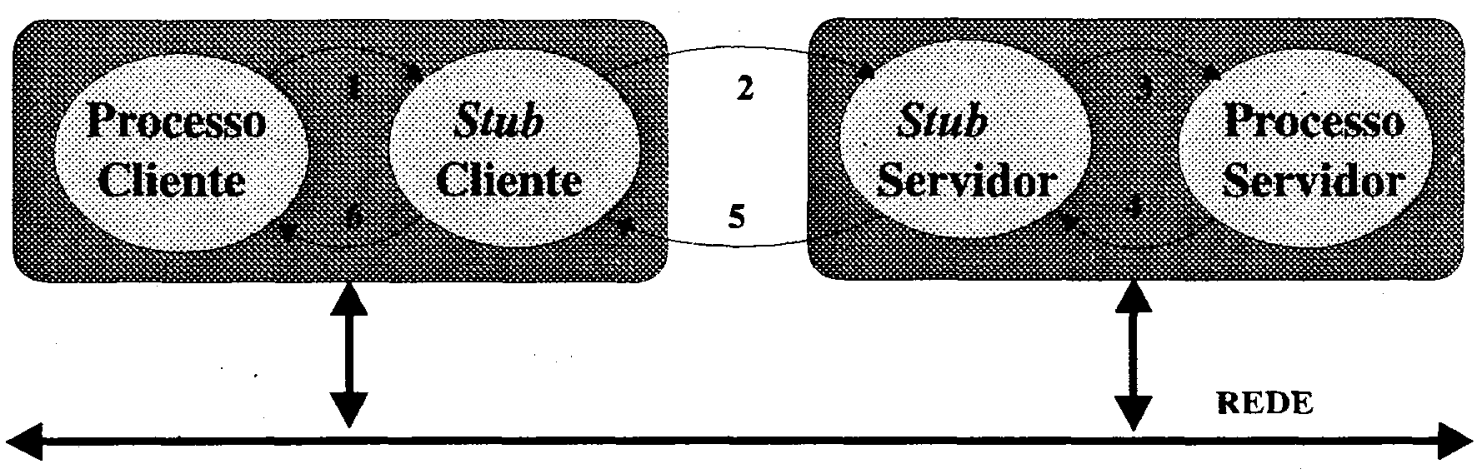

1e3-Chamadas de Procedimentos Normais

2 e 5 -Mensagens através da Rede

4 e6-Respostas a Chamadas de Procedimentos Remotos

Fig. 4.4 - Chamada de Procedimento Remoto 


\subsection{Protocolos - Considerações Gerais}

Apesar do modelo ISO/OSI ter sido definido com as redes a longa distância em mente, ele é um ponto de referência no projeto de software de redes em geral. Entretanto, o modelo ISO impõe muitos requisitos para sua implementação o que dificulta sua utilização em sistemas distribuídos baseados em redes locais [CO88]; modelos mais simples são normalmente adotados nesses sistemas.

Para se obter melhor desempenho, o objetivo é fazer com que processos clientes possam se comunicar com processos servidores com um atraso mínimo. Os atrasos envolvidos na tranșmissão de uma mensagem são compostos por latência (sobrecarga causada no início da comunicação) e por um tempo de transmissão proporcional ao número de bits transmitidos [CO88].

Para minimizar a latência, a transferência de controle entre módulos de software e a cópia de dados entre os processos deve ser otimizada. A maior parte da responsabilidade com os reconhecimentos, deteç̧ão de erros, conversões entre representações de dados e manipulação de erros para assegurar uma comunicação confiável pode ser tratada no nível de aplicação - pelo software de chamada a procedimentos remotos ou pelos programas cliente ou servidor - reduzindo a complexidade do protocolo e a sobrecarga nas camadas mais baixas. Isso é possível devido à alta confiabilidade oferecida pelas redes locais. Nelas não é necessário fazer o roteamento de pacotes, assim a camada de rede que é responsável pelo roteamento no modelo ISO/OSI se torna redundante. Assim um protocolo a nível de transporte e uma camada de enlace de dados são suficientes para dar suporte às necessidades da maioria dos sistemas distribuídos baseados no paradigma cliente-servidor [CO88].

Experiências com a utilização do protocolo TCP/IP durante vários anos mostrou que escolhas cuidadosas na implementação dos protocolos podem trazer ganhos enormes no seu desempenho [CO91].

\subsection{RPC - Considerações Gerais}

Apesar do mecanismo de chamada a procedimentos remotos ser utilizado frequentemente como um paradigma familiar para se dividir aplicações através de várias máquinas, o uso de servidores compartilhados por vários clientes é uma estrutura de sistemas distribuídos facilmente encontrada [WI87]. Claramente, chamadas a 
procedimentos remotos fornecem mecanismos adequados para comunicação entre processos para tais sistemas, mas a eficiência deve ser tão considerada como, por exemplo, a transparência, citada no item 4.2.1.

Se for considerado um servidor simples, que não faça chamadas a outros servidores, para se executar uma chamada pode ser que seja necessário ter acesso a um recurso que não esteja disponível no momento, por exemplo um arquivo compartilhado que esteja "travado". Esse "atraso local" degrada o desempenho do sistema e não é possível que o servidor atenda nenhuma outra chamada durante esse atraso. Um outro tipo de atraso, conhecido como "atraso remoto", pode ocorrer quando um servidor chama uma função remota que envolve uma considerável quantidade de cálculos ou envolve um grande atraso de transmissão. $\mathrm{Na}$ ausência desses atrasos os servidores serão eficientes ao máximo, se as chamadas que chegam forem atendidas serialmente. Entretanto, boas implementações de sistemas de chamadas a procedimentos remotos devem fornecer mecanismos para permitir que se construa sistemas eficientes apesar desses atrasos, e isso implica que o servidor deva ser capaz de atender múltiplas requisições simultaneamente, ou retornar algum aviso ao cliente para que assim ele possa ou localizar um outro servidor ou começar alguma outra atividade.

Trabalhos anteriores mostram que a eficiência é melhorada se os computadores não possuírem espaços compartilhados [BI84].

\subsection{Desempenho em RPCs}

Nesse item serão discutidos alguns pontos relevantes para o desempenho de sistemas RPC. A título de comparação, nota-se que uma chamada local a um procedimento requer cerca de 0,01 a $0,1 \mathrm{~ms}$ para ser executada [WI87].

Spector [SP82] descreve chamadas remotas altamente otimizadas usando um protocolo projetado especialmente com suporte de hardware.

Birrel e Nelson [BI84] discutem RPCs baseadas em um protocolo de transporte mais generalizado. Eles registraram tempos na faixa de 1 a $3,5 \mathrm{~ms}$ utilizando uma Ethernet similar ( $3 \mathrm{MHz}$ ), sem suporte de hardware, mas utilizando computadores Dorado, com desempenho superior aos computadores ALTO.

Esses resultados são considerados ótimos. É interessante considerar os fatores que contribuem para o tempo gasto para executar uma chamada remota. Segundo Coulouris [CO88] têm-se:

1. empacotamento e desempacotamento dos argumentos e resultados, no servidor e no cliente, 
2. transmissão pela rede em ambas direções,

3. tempo para a execução do procedimento remoto, $\mathrm{e}$

4. tempo para ser atendido pelo servidor.

Se o servidor consiste de um único processador, então os clientes são colocados em rede e o tempo depende em quão ocupado estiver o servidor. Se o servidor cria um novo processo a cada chamada, o tempo dependerá do tempo de criação do processo.

Duas diferentes implementações de chamadas a procedimentos remotos, disponiveis para o sistema operacional UNIX (Courier e Admiral), executam cada chamada numa faixa de 10 a $20 \mathrm{mseg}$ (com um argumento e resultado inteiro) considerando uma estação Sun-2 e uma rede local Ethernet a $10 \mathrm{MHz}$ [RO85]. Admiral geralmente apresenta um desempenho melhor do que o Courier. Isso é atribuído ao fato de que o Courier cria um novo processo UNIX para cada chamada e utiliza TCP/IP para troca de mensagens; Admiral tem um sistema de processos único e usa comunicação por datagramas. Wilbur [WI87] relata que o sistema Admiral gasta por volta de $8 \mathrm{~ms}$ para chamar um procedimento nulo mais cerca de $0,013 \mathrm{~ms}$ por byte para transmissão de argumentos ou resultados entre estações Sun-3, considerando-se uma rede Ethernet.

Os tempos (1), (3) e (4) citados acima, segundo [WI87], são significantemente importantes. Se forem comparadas estações Sun-2 e Sun-3, o tempo de chamada é reduzido de 18 para $7,5 \mathrm{~ms}$ e o tempo por byte de 0,05 para $0,013 \mathrm{~ms}$.

A figura 4.5 ilustra o tempo médio gasto por uma chamada remota com a variação do tamanho dos parâmetros. Nessa implementação particular de RPC [WI87] uma chamada para um procedimento nulo sem parâmetros e sem resultados leva cerca de 13 useg por byte. Esses tempos foram medidos para chamadas entre dois processos em estações SUN 3, numa Ethernet de $10 \mathrm{Mbps}$. Em outras implementações, tem-se esforçado bastante para reduzir o custo de uma chamada nula para cerca de $1 \mathrm{~ms}$, enquanto outras utilizando um transporte orientado a conexão somente alcançaram tempos de $35 \mathrm{~ms}$ para uma chamada nula. 


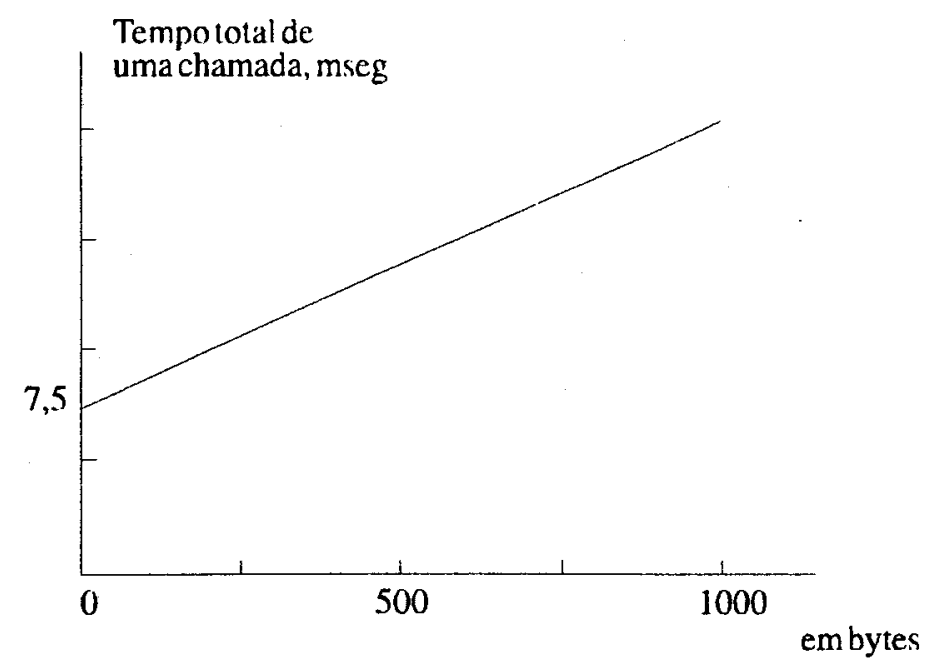

Fig. 4.5 - Desempenho Típico de uma Chamada Remota

Embora o mecanismo de chamada remota a procedimentos seja de propósito geral, em aplicações práticas essas chamadas remotas irão incluir uma sobrecarga 2 ou 3 vezes maior que a sobrecarga causada pelas chamadas locais. Esse impacto força o programador a considerar cuidadosamente como será feita a separação do sistema em módulos e como projetar as interfaces para que o fluxo de comunicação seja mínimo. Tal separação geralmente faz com que o programador tenha uma visão orientada a objeto do servidor, isto é, chama o servidor para executar operações ao invés de transferir estruturas de dados para o cliente. Isso não só melhora o desempenho da aplicação, mas também melhora sua modularidade [WI87].

Se forem observados os custos envolvidos numa chamada a procedimento remoto, de acordo com Wilbur [WI87], na ausência de erros na rede de comunicação, têm-se:

\section{tempo de chamada $=$}

empacotamento dos parâmetros + enfileiramento para transmissão + transmissão na rede

+ enfileiramento e escalonamento no servidor + desempacotamento dos parâmetros + execução

+ empacotamento dos resultados + enfileiramento para transmissão + transmissão na rede

+ escalonamento no cliente + desempacotamento dos resultados.

Que também pode ser escrito como:

\section{tempo de chamada $=$}

transformação dos parâmetros

+ transmissão na rede

+ execução

+ atrasos do sistema operacional. 
As transformações de parâmetros são necessárias para sistemas de chamada a procedimentos remotos heterogêneos de propósito geral, embora o conhecimento do ambiente do sistema possa permitir que se façam otimizações para se reduzir esse componente do custo. Para chamadas com poucos parâmetros, o principal fator da sobrecarga serão os atrasos do sistema operacional, atrasos esses devidos ao chaveamento de contexto, funções de roteamento do sistema operacional, enfileiramento para transmissão, escalonamento e "swapping", se necessário [WI87].

Até este ponto, foram analisados, os custos por chamada. A maioria dos servidores implementa uma coleção de funções relacionadas, e durante uma associação cliente-servidor o cliente vai fazer várias chamadas a elas. Do ponto de vista do cliente o custo dessa associação será:

tempo de associação = tempo de alocação do servidor

+ tempo de criação do servidor

$+\mathrm{N} x$ tempo de chamada

+ tempo de notificação de término do servidor

para uma associação com $\mathrm{N}$ chamadas. Em sistemas com servidores pré-criados, localizados em endereços conhecidos, os tempos de criação e de término são reduzidos a zero. Servidores criados dinamicamente podem levar um tempo de chamada extra para invocar o gerenciador do servidor, juntamente com a criação do processo ou tarefa ou ainda o tempo de alocação, e uma chamada extra para terminá-los. Então para servidores dinâmicos o custo de chamada é aproximadamente:

tempo efetivo de chamada $=((\mathrm{Nx} 4) \times$ tempo de chamada + tempo de criação de processo)/N

Para servidores que possuem um pequeno número de chamadas por associação, nota-se que o tempo efetivo de chamada pode ser aumentado.

Aplicações que necessitarem mais de 50 a 100 chamadas remotas por segundo, podem não ser viáveis com a maioria das implementações de sistemas RPC. Entretanto, algumas aplicações que requeiram taxas de chamadas mais altas, podem ser acomodadas se os parâmetros forem armazenados. Isto só pode ser feito quando a seqüência de chamadas não retornar resultados. Esse armazenamento acontece da seguinte maneira: o $s t u b$ do cliente reconhece esses procedimentos e então acrescenta os seus parâmetros a um buffer para transmissão, só o envia quando passa um intervalo de tempo pré-determinado, quando um razoável número de parâmetros forem empacotados ou quando for chamado um procedimento do servidor que retorna resultados. Essa otimização pode causar obscuros efeitos relacionados com o tempo, pois vários clientes podem estar utilizando o servidor simultaneamente. 


\subsection{Considerações Finais}

A importância das trocas de mensagens em sistemas distribuídos vem do crescente interesse em processamento paralelo. Implementações com memória compartilhada não têm mais sentido, pois no ambiente distribuído a troca de mensagens é o paradigma mais natural [CH90].

Processamento distribuído enfatiza a importância da transparência e da independência de máquina em um sistema, pontos que podem ser alcançados com a utilização da troca de mensagens.

O mecanismo RPC é útil na construção de aplicações distribuídas, mesmo considerando os aspectos que o diferenciam das chamadas locais e que impõe algumas restrições de desempenho e dificuldades de implementação.

RPC é uma ferramenta muito utilizada para aplicações distribuídas. No entanto é necessário que se faça das chamadas a procedimentos remotos um mecanismo eficiente e elegante.

Embora o desempenho das chamadas a procedimentos remotos seja significantemente inferior ao das chamadas locais, se as interfaces forem cuidadosamente estruturadas, esse efeito pode ser minimizado para a maioria das aplicações. Nos casos onde se necessita um desempenho melhor, pode-se utilizar protocolos altamente otimizados ou utilizar o armazenamento dos parâmetros.

No próximo capítulo apresenta-se uma revisão da implementação original do SPP (Sistema de Processamento Paralelo) e alguns pontos estudados e alterados visando a ampliação do mesmo. 


\section{Capítulo 5}

\section{Revisão/Ampliação da Implementação Original do SPP}

O servidor de processamento paralelo desenvolvido no LaSD, conforme citado no capítulo 1, permite que diversos usuários compartilhem as unidades de processamento disponíveis no Banco de Transputers (BT). O banco permite, na versão implementada, que no máximo 4 usuários compartilhem os transputers disponíveis. A utilização dos processadores do banco é feita através do estabelecimento de uma sessão de trabalho, que na prática funciona como uma conexão lógica entre a estação de trabalho do usuário e o SPP. O usuário solicita um lote de transputers e efetua, dinamicamente, a configuração da arquitetura que deseja utilizar.

Os serviços de controle de acesso concorrente ao banco de transputers, bem como a comunicação com os usuários, são implementados no "processador de entrada" (PE) que implementa um "front-end" interligando a rede local com o BT.

Durante a utilização experimental do protótipo do SPP, constatou-se que, apesar de operando satisfatoriamente para uma primeira versão, o sistema ainda requer certos ajustes visando melhor desempenho no sistema de comunicação (basicamente o sistema de protocolos implementados) [TR91].

O protocolo de comunicação utilizado no SPP foi implementado segundo o paradigma cliente-servidor, utilizando um mecanismo de chamada de procedimentos remotos (Remote Procedure Call - RPC), conforme visto no capítulo 4.

Existe um conjunto básico de primitivas que o cliente pode executar no BT, descritas no apêndice A. Para que a execução seja efetuada o cliente transmite um código de primitiva, juntamente com seus parâmetros, e aguarda resposta durante um intervalo de tempo. Caso a resposta não retorne no tempo estimado, o cliente retransmite a operação desejada até obter uma resposta ou esgotar um número máximo de tentativas. $\mathrm{O}$ servidor, caso receba um mesmo pedido mais de uma vez, identifica que se trata de uma mesma requisição e devolve a resposta processada anteriormente (semântica "at-mostonce").

Na primeira versão não foi efetuado um estudo pormenorizado do tempo gasto para a execução de cada primitiva no servidor, ficando em aberto os níveis obtidos e o impacto gerado pelas decisões tomadas. 
Este capitulo apresenta uma revisão geral do SPP incluindo estudo pormenorizado do protocolo implementado e sugestões de modificações visando melhorias no sistema.

\subsection{Organização do SPP}

Os itens a seguir apresentam o software e o hardware com a implementação original do sistema SPP.

\subsubsection{Hardware}

Em [PA93a] foi apresentada uma visão geral e detalhada do SPP. Esse item dará uma breve descrição física do sistema, visando a compreensão dos detalhes descritos nos demais itens.

O conjunto SPP é formado por vários elementos diferentes que se comunicam e cooperam para realizar a função a que se propõe: "fornecer recursos computacionais para programação paralela através de uma rede local de computadores".

Os elementos de hardware que fazem parte do SPP estão listados abaixo seguidos de uma breve descrição de sua função no sistema, e podem ser identificados na figura 5.1.

- PE - Processador de Entrada

Está ligado às Estações de Trabalho através da rede local e ao Controlador de Módulo. Na versão atual, sua principal função é fazer a interface entre as ET's e o Banco de Processadores.

- CM - Controlador de Módulo

Faz o controle dos processadores do Banco (Módulo) além de gerenciar a comunicação. É formado por uma placa de Transputer - T800 e por uma interface que controla o barramento e os canais de comunicação com o banco. Também é responsável por configurar a rede de chaveamento (RC).

- RC - Rede de Chaveamento

É configurada pelo CM através de um canal de configuração. Sua função é fazer a conexão entre "links" dos Transputers do banco com o objetivo de formar as redes de processadores. Da forma como está implementada permite a criação de qualquer topologia usando os processadores disponíveis.

- ET - Estação de Trabalho

No sistema SPP, qualquer computador compatível com PC/AT/XT, ligado à rede local do sistema, pode ser transformado em uma ET, bastando para isso, a instalação 
dos softwares necessários.

- P1-Pn - Elementos processadores a serem compartilhados

Cada "processador" do banco é um computador completo com memória RAM variando entre 1 e 4 MBytes. Possuem uma interface com o barramento do banco, através da qual são controlados pelo $\mathrm{CM}$. A unidade central de processamento é o Transputer NMOS-T800.

\section{Servidor de Processamento Paralelo}

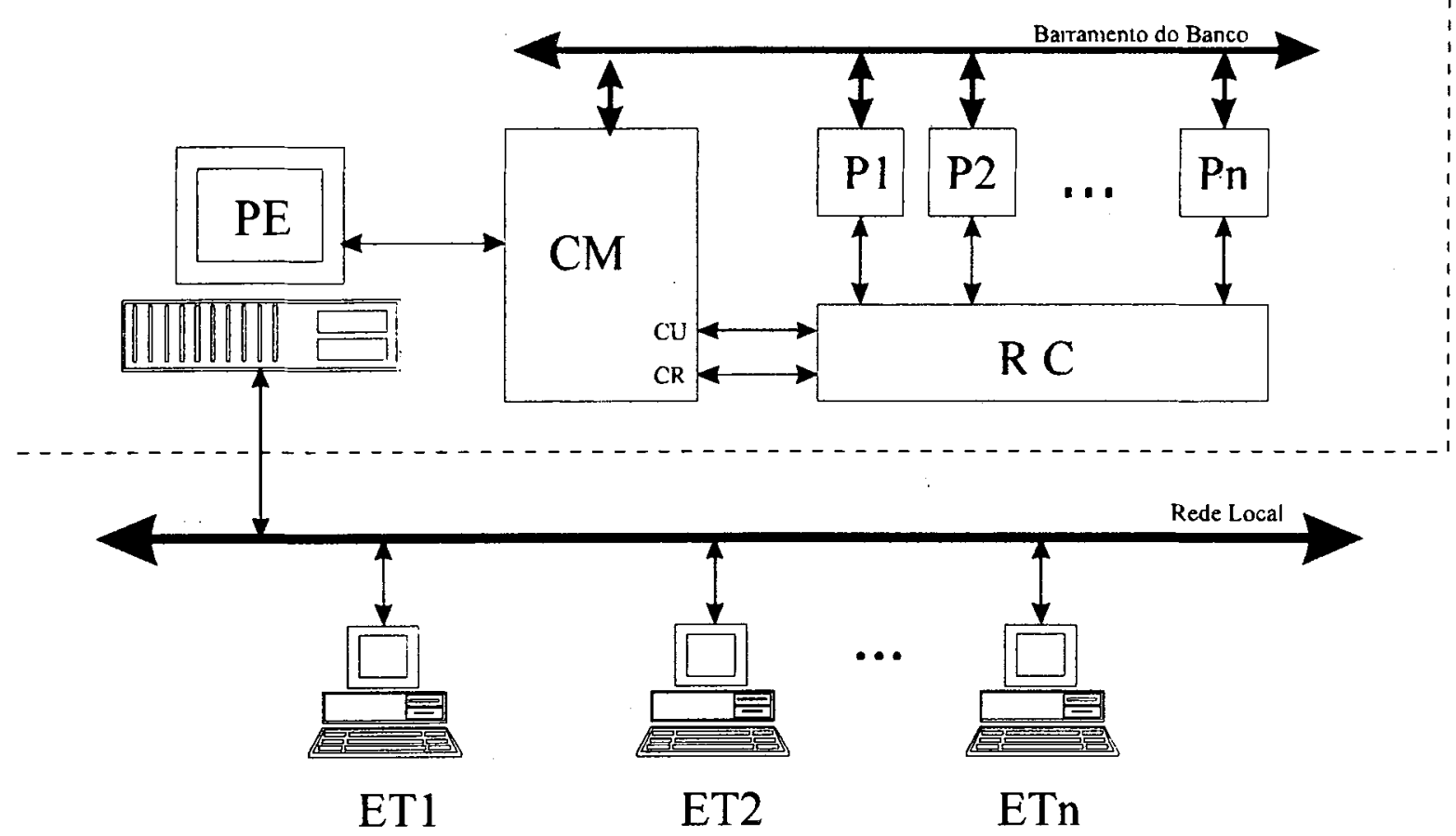

CU - Canais de usuário

CR - Canal de configuraçăo da rede

Fig. 5.1 - Estrutura do Hardware do SPP

\subsubsection{Software}

O software que compõe o SPP é dividido entre estação de trabalho e servidor. Nos próximos itens detalha-se cada um deles. 


\section{- Estação de Trabalho}

O software da Estação é composto por um conjunto de programas que devem ser devidamente instalados e executados para que o sistema possa funcionar de forma adequada, conforme descrito no apêndice $\mathrm{A}$.

O TDS ("Transputer Development System") [IN90] foi o primeiro aplicativo disponível no BT. No item 5.3 descreve-se com mais detalhes a instalação do TDS ao SPP. Para se ter acesso ao TDS, de uma estação de trabalho, tendo o software devidamente instalado deve-se substituir o arquivo iserver.exe pelo iserver modificado iserverb.exe.

Utilitários de acesso às primitivas do servidor:

- login.exe

- logout.exe

- lot.exe

- dlot.exe

Arquivos usados pelo sistema, associados ao mecanismo de comunicação e que devem estar instalados e disponíveis na ET:

- iniseq.exe

- termpd.exe

O utilitário iniseq.exe é utilizado somente na versão original, com a semântica "atmost-once".

O mecanismo RPC implementado através do protocolo SPP faz acesso à rede com auxílio do "packet driver", portanto, o software do "packet" deve ser instalado na estação para que o sistema funcione. Isso é feito executando-se os programas ne1000.exe ou ne2000.exe com os respectivos parâmetros de configuração, dependendo da placa de rede instalada na ET. Caso a estação seja dedicada ao SPP, esses programas podem ser executados a partir do autoexec.bat da máquina.

Com todos os programas citados acima instalados, a estação está pronta para compartilhar os recursos do SPP.

\section{- Servidor}

Basicamente o software do servidor do SPP é constituído por 2 programas, 
executados no PE e no CM respectivamente.

- serv.exe

- bt.t8

O programa serv.exe é executado no $\mathrm{PE}$, sendo responsável pela comunicação com às ET's através do mecanismo RPC implementado e com o $\mathrm{CM}$. Foi desenvolvido em linguagem $\mathrm{C}$.

O programa bt.t8 gerado a partir da compilação do programa occam bt.tsr, descrito no documento [PA93b], é executado pelo Transputer do Controlador de Módulo.

Para a inicialização do servidor existe uma seqüência que deve ser seguida:

1. Deve-se carregar e executar o programa bt.t8 na placa do Controlador de Módulo. Isso é feito por um arquivo em lote, bt.bat, contendo os seguintes comandos:

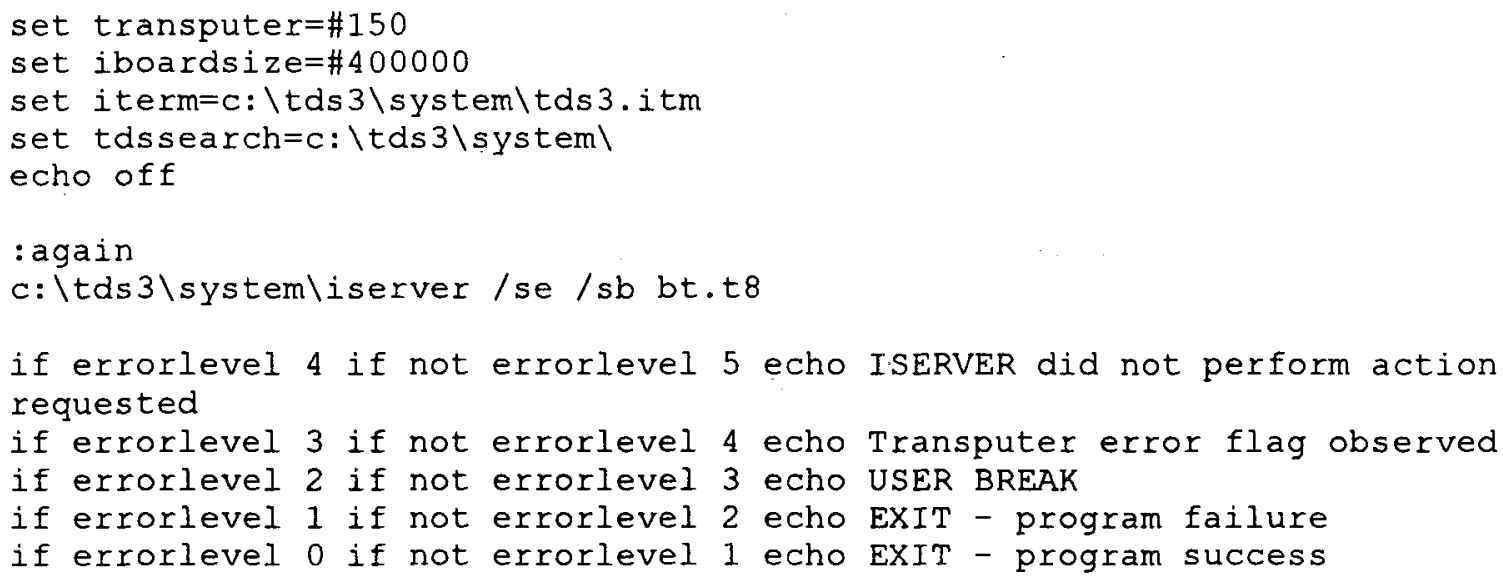

Depois de carregado o programa bt.t8 para o CM, deve-se abortar o programa iserver que está executando no $\mathrm{PE}$, o que pode ser feito através do comando $<$ CRTL $>+<\mathrm{C}>$, digitando-se $<\mathrm{x}>$ quando solicitado.

2. Executar o programa serv.exe. Após esses passos, um usuário em uma ET, já pode ter acesso ao sistema.

\subsection{Projeto e Implementação do Software Original}

Neste item são apresentadas as fases de projeto e implementação do sistema original. O projeto segue as diretrizes do projeto estruturado de sistemas [PA88], que tem como principal ferramenta o diagrama de estrutura modular. Para maior clareza nos 
diagramas, não estão representados os parâmetros de interface dos módulos.

\subsubsection{Descrição dos Protocolos, Pacotes e Estruturas de Dados}

O formato dos diversos tipos de pacotes de dados utilizados pode ser observado na figura 5.2. O pacote de mais baixo nível que circula pela rede local Ethernet é mostrado na figura 3.7. Esse pacote, eliminados os campos de preâmbulo e CRC ("Cyclic Redundancy Code"), resulta no pacote tipo PKT, empregado na interface com o "packet driver" NCSA.

O protocolo de comunicação do modelo cliente-servidor foi baseado em um mecanismo RPC que utiliza o pacote de dados SPP. Esse pacote é transmitido dentro do pacote PKT, apresentando os seguintes campos:

$\rightarrow$ TP - Tipo do Protocolo. Esse campo permite a utilização de mais de um protocolo por tipo de pacote em futuras expansões do sistema.

$\rightarrow$ DT - Destino. Indica o destino do pacote.

$\rightarrow$ PR - Identificador da primitiva. Código da primitiva do sistema SPP. As seguintes faixas de código estão definidas:

$0 \times 00-0 \times 3 f$ primitivas atendidas pelo $\mathrm{PE}$

$0 \times 40-0 \times 7 f$ primitivas atendidas pelo $\mathrm{CM}$

$\rightarrow$ ET - Estado. Informações diversas sobre a requisição ou resposta da primitiva, codificadas bit a bit:

b7 $\rightarrow$ seqüência de chamada da primitiva

b6 $\rightarrow$ uso futuro

b5 $\rightarrow$ erro na execução da primitiva

b4 $\rightarrow$ requisição não válida

b3 $\rightarrow$ primitiva não existe ou permissão negada

b2 $\rightarrow$ sessão não existe

b1 $\rightarrow$ "time out" na execução da primitiva

b0 $\rightarrow$ uso futuro

$\rightarrow$ TM - Tamanho do pacote SPP.

O protocolo SPP dá suporte direto ao mecanismo RPC. Não são utilizadas chamadas aninhadas de procedimento, apesar de suportadas. Cada requisição e cada resposta ocupam um único pacote SPP, em ordem estrita, isso é, somente podem ser feitas 
novas requisições uma vez recebida a resposta da requisição anterior. A política adotada para o tratamento de falhas é "no máximo uma execução" [WI87]. O paradigma intrínseco do mecanismo RPC e as restrições acima simplificam a tarefa de validar o protocolo utilizado.

PACOTE PKT

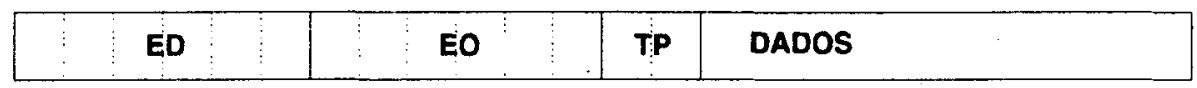

ED - endereço ethernet destino

EO- endereço ethernet origem

TP. tipo do pacote (blue-book ethernet)

PACOTE SPP

\begin{tabular}{|l|l|l|l|l|l|}
\hline TP & DT & PR & ET & TM & PARAMETROS \\
\hline
\end{tabular}

\footnotetext{
TP. tipo do protocolo (b7 -> requisiçao/resposta)

DT - destino (processo/sessao)

PR- identificador da primitiva

ET - estado

TM - tamanhodopacoteSPP
}

PACOTE SP*

\begin{tabular}{|l|l|l|l|l|l}
\hline BO & B2 & MENSAGEMIPARAMETROS
\end{tabular}

\begin{tabular}{|c|c|}
\hline $\mathrm{BO}<>0$ & $B 0+256^{*} B 1=$ tamanho da mensagem SP \\
\hline $\mathrm{BO}=$ & $\begin{array}{l}\mathrm{B} 1=\text { identificador da primitiva SPP } \\
\mathrm{B} 2+256^{*} \mathrm{~B} 3=\text { tamanho do pacote SP* }\end{array}$ \\
\hline
\end{tabular}

Fig. 5.2 - Definição dos Pacotes de Dados

O protocolo SP* é baseado no protocolo INMOS SP, utilizado pelo sistema de desenvolvimento TDS [IN90]. 
Diversas estruturas de dados foram utilizadas na implementação do software do sistema SPP. Apresenta-se a seguir aquelas relacionadas com a operação básica do sistema e que podem contribuir para o seu entendimento.

Estruturas de dados na estação de trabalho:

Tabela de servidores - TSERV (indexada pelo ide_servidor) end_serv[] - endereço do servidor ide_sessão[] - identificador da sessão do usuário seq[] - sequiência de requisição para cada primitiva to[] - contador de "time out" para cada primitiva

Estruturas de dados no processador de entrada:

Tabela de sessões - TSES (indexada pelo ide_sessão) cod_usu - código de identificação do usuário end_est[] - endereço da estação ide proc - identificador do processo do usuário seq[] - seqüência de requisição de cada primitiva tam_resp[] - tamanho máximo da resposta para cada primitiva ${ }^{*}$ resp[] - ponteiros para as últimas repostas de cada primitiva

Tabela de Usuários - TU (indexada pelo cod_usu) nome_usu[] - nome do usuário senha[] - senha do usuário perm[] - permissão de execução para cada primitiva extensão - estatística e histórico de utilização (uso futuro)

Estruturas de dados no controlador de módulo:

Tabela de Processadores - TP (indexada pelo número do conector do módulo onde cada processador está fisicamente alojado)

Tabela de lotes - TLOT (indexada pelo ide_lote)

ide_sessão - identificador da sessão

conf_atual[] - configuração do lote, conforme o formato (para cada processador pertencente ao lote).

\subsubsection{Estações de Trabalho}

Os diagramas de estrutura modular correspondentes às tarefas executadas nas estações de trabalho aparecem na figura 5.3. Observa-se nessa figura a estrutura de 
chamada de uma primitiva genérica.

Cada primitiva tem associado um valor de tempo ("time out"), após o qual é feita uma nova requisição, conforme a política de tratamento de falhas implementada. Após um certo número de falhas, especificado pela constante do sistema TIME_OUT_SPP, considera-se que o servidor não pode atender a requisição $e$ as tentativas são interrompidas.

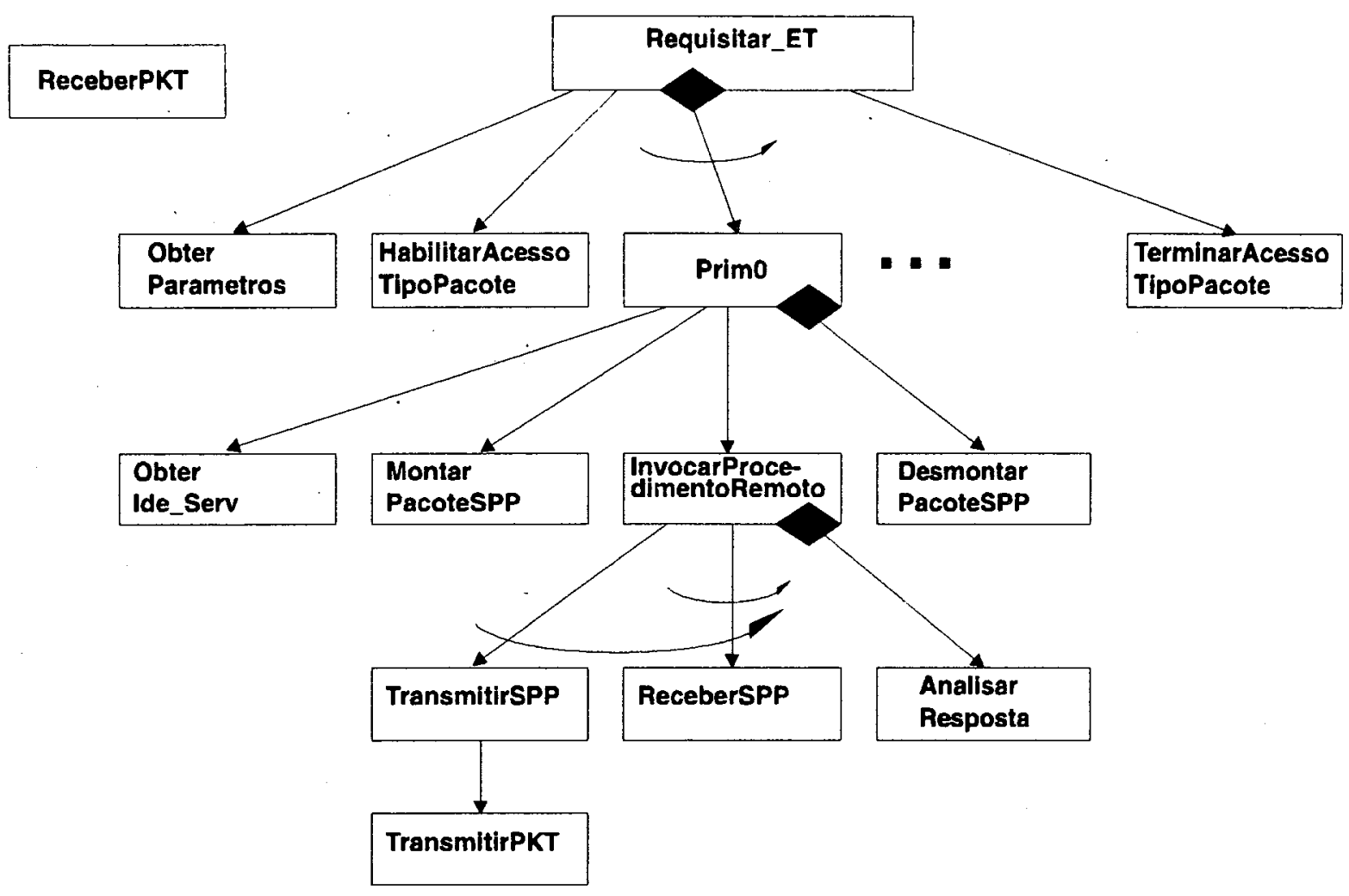

Fig. 5.3 - Diagrama de Estrutura Modular - Estação

\subsubsection{Processador de Entrada}

O processador de entrada está diretamente acoplado à rede local, comunicando-se através dela com as estações de trabalho. Também se comunica com o banco de Transputers. Sua função principal consiste no roteamento de pacotes entre as estações de trabalho e o banco.

O diagrama de estrutura modular correspondente às tarefas executadas no PE é apresentado na figura 5.4 . 


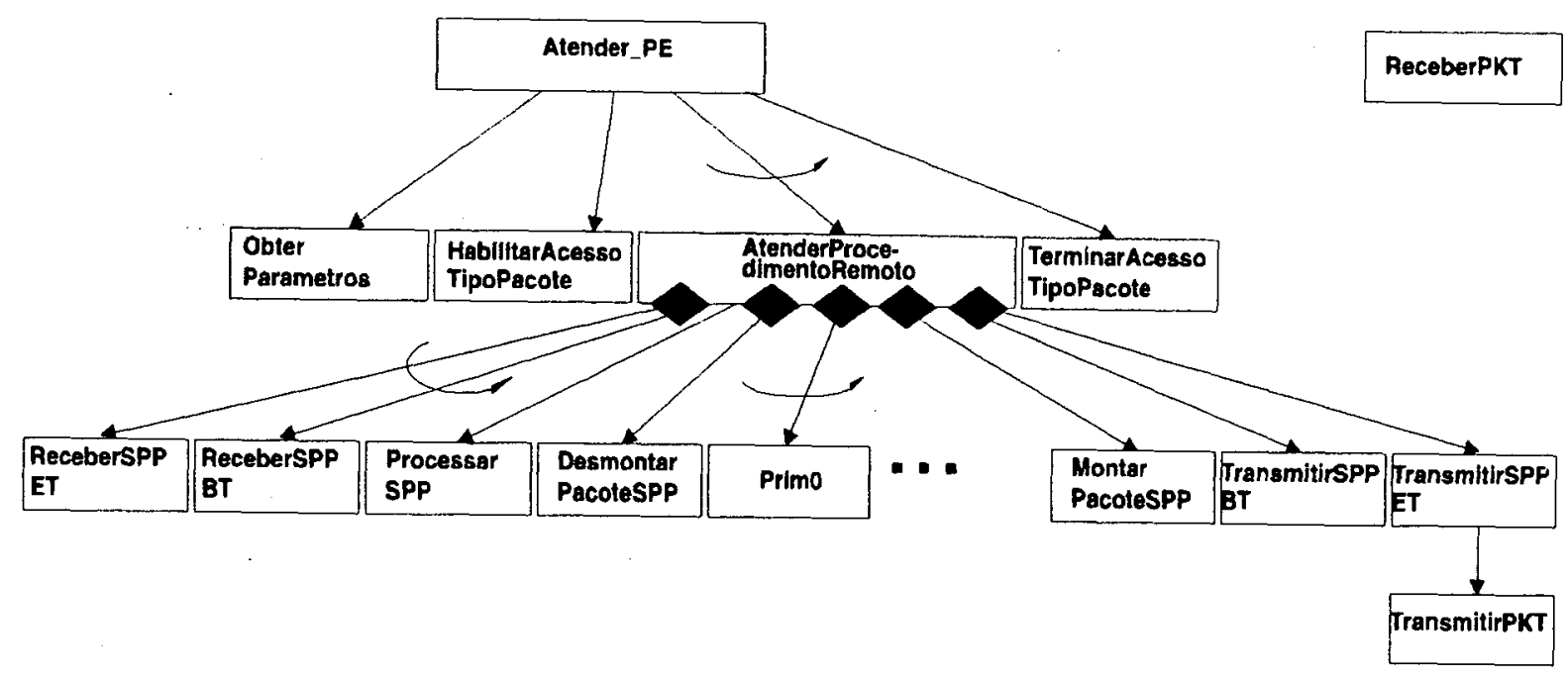

Fig. 5.4 - Diagrama de Estrutura Modular - Servidor

Algumas primitivas do mecanismo RPC são atendidas pelo processador de entrada. Entre essas estão as primitivas de controle de acesso ao sistema:

$\rightarrow$ Login (nome_usuário, senha, *ide_sessão) - Inicia uma sessão no servidor.

$\rightarrow$ Logout (ide_sessão) - Encerra uma sessão no servidor.

\subsection{Instalação do Sistema de Desenvolvimento TDS}

A instalação do sistema de desenvolvimento TDS introduz no sistema SPP ferramentas para o desenvolvimento de programas na linguagem Occam. Isso possibilita um mínimo de funcionalidade para o sistema.

\subsubsection{Organização do Sistema de Desenvolvimento TDS}

O TDS pode ser migrado para diferentes máquinas e utilizado com vários sistemas baseados em transputers (T400, T800). Essa flexibilidade é possível porque a INMOS fornece o código fonte do aplicativo "iserver", permitindo que sejam feitas as alterações necessárias para que se consiga a configuração desejada do ambiente TDS.

O sistema de desenvolvimento TDS consiste em um módulo executado no computador hospedeiro, o ISERVER [IN90], e um módulo principal, o TDS, executado no processador raiz de uma rede de Transputers. O ISERVER possibilita o carregamento de programas objeto no processador raiz da rede e pode permanecer ativo, atendendo 
requisições de serviços relativos a arquivos, vídeo e teclado provenientes do TDS ou de um programa do usuário.

A organização geral do software do sistema, bem como a interrelação entre os diversos módulos que o compõem são apresentadas na figura 5.5. De acordo com a organização do iserver, todos os procedimentos que interagem com a placa do transputer estão localizadas no módulo b004link.c e aparecem tracejadas na figura 5.5.

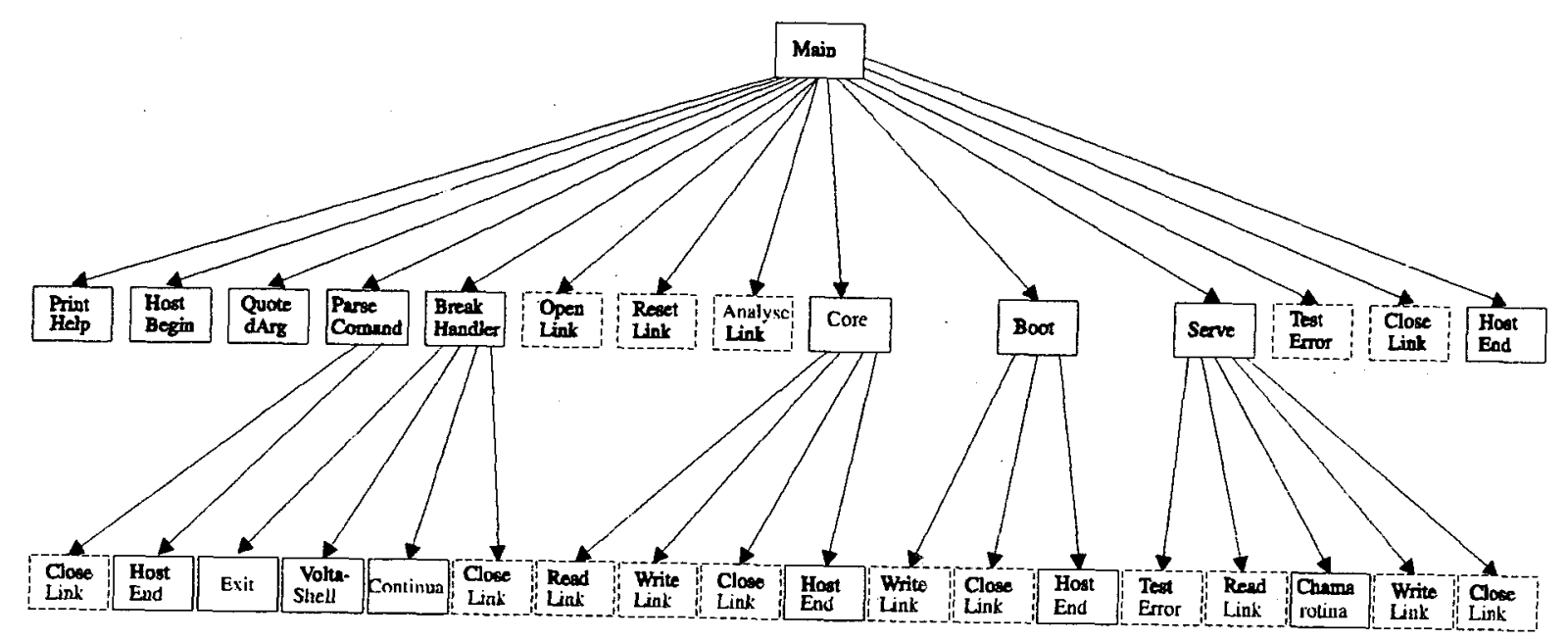

Fig. 5.5 - Diagrama de Estrutura Modular - ISERVER

A função original dos módulos do ISERVER foi na maioria dos casos preservada, conforme descrição em [AN93].

O sistema RPC desenvolvido foi incorporado ao servidor a partir do módulo b004link.c, conforme ilustra a figura 5.6.

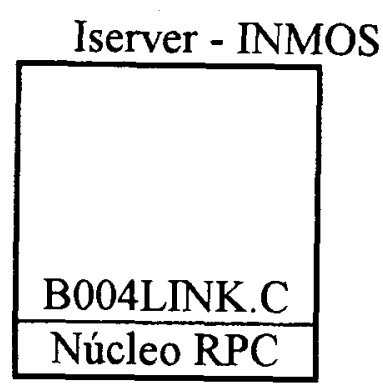

Fig. 5.6 - Incorporação do Núcleo RPC ao Servidor INMOS 


\subsection{Decisões de Projeto}

Como é de interesse que o SPP se torne um sistema disponível para diferentes ambientes, a primeira decisão tomada foi a migração do software do SPP, desenvolvido originalmente no Microsoft C - 6.0 - ambiente PWB, para o ambiente Turbo C. O objetivo dessa migração foi principalmente o fato de se ter interesse em continuamente atualizar e completar o sistema SPP. E como descreve-se no capítulo 6, o software do SPP foi incorporado a uma implementação do conjunto de protocolos TCP/IP e os códigos-fonte disponíveis desta implementação estão escritos em Turbo-C, justificando assim essa migração.

A migração do sistema para o ambiente Turbo-C, à principio, não foi efetuada de maneira tão simples. O software do SPP é longo e complexo tendo apresentado vários problemas com as representações dos dados. Foi necessário um estudo do adequamento da linguagem $C$ às duas versões de compiladores, sendo que algumas diretivas de compilação foram alteradas e outras inclusive retiradas.

Uma outra decisão tomada com o intuito de se melhorar o entendimento do software desenvolvido foi a de se reescrever em $\mathrm{C}$ as rotinas de comunicação com o "packet driver", escritas inicialmente em "assembly". Isso facilita bastante possíveis mudanças futuras que se façam necessárias.

A única rotina para a qual foi mantido o código original, em "assembly", é a rotina de recepção. Essa decisão ocorreu porque é a rotina que faz a interface direta com o "packet driver", devendo ser escrita em "assembly".

Alguns pontos pendentes na versão preliminar do sistema SPP foram concluídos nesta etapa do trabalho. Um exemplo é o tratamento de "login" ao sistema. Existia no servidor uma tabela fixa com o nome dos usuários que tinham permissão para utilização do sistema, assim a tabela de usuários era inicializada em tempo de execução, da seguinte maneira:

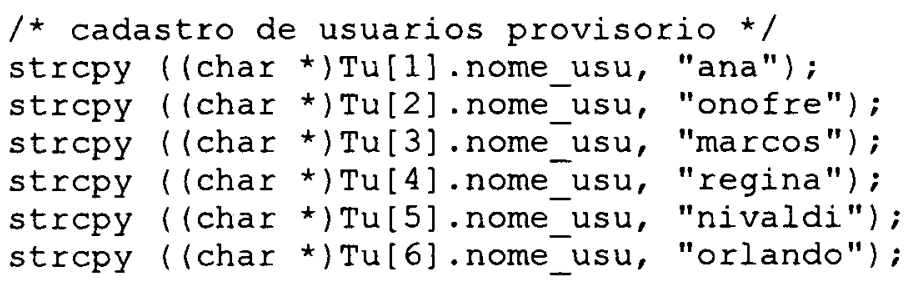

A inclusão de um novo usuário no sistema, implicava na modificação do código fonte e na necessidade de se compilar o software novamente. 
Foi desenvolvido um programa auxiliar que trata do cadastramento de clientes ao sistema. Esse cadastramento é feito em arquivo e quando o servidor é colocado no ar, a tabela do usuário, localizada no servidor, é carregada diretamente do arquivo. Esse sistema permite que se inclua usuários no sistema, verifica se um dado usuário faz parte ou não do sistema e carrega o arquivo de usuários para a tabela de usuários, se necessário. Assim para se incluir um novo usuário no sistema, basta executar o sistema cadastra, e efetuar o cadastramento. Dessa forma o código no servidor ficou da seguinte maneira:

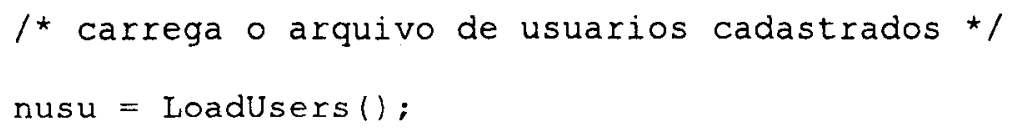

sendo que na variável nusu fica armazenado o número de usuários que estão na tabela.

Para o desenvolvimento do núcleo RPC adotou-se a semântica "at-most-once", por oferecer uma solução de compromisso entre desempenho e confiabilidade, além de permitir implementação simplificada e que se alcance os objetivos desejados. Como a tecnologia de redes locais tem se mostrado cada vez com mais confiabilidade, com uma taxa de erros mínima, uma outra tentativa de se melhorar o desempenho foi a implementação da semântica "at-least-once", descrita no próximo item.

\subsection{Projeto Lógico}

Como visto no item 5.4, uma das modificações efetuadas no sistema original foi de se fazer uma nova implementação da semântica de comunicação do núcleo de RPCs. Na tentativa de se melhorar o desempenho da troca de mensagens, tentou-se alterar a semântica "at-most-once", originalmente implementada, para a semântica "at-least-once".

Essa modificação acarreta algumas alterações no projeto lógico do software do SPP. Na implementação da semântica "at-most-once", existe um mecanismo rígido para controle do número de seqüência das primitivas (para garantir que a primitiva seja executada apenas uma vez) que é efetuado conforme descrito a seguir.

Quando uma estação inicia suas operações, assume-se que não existem requisições pendentes no servidor. É acrescentado um campo de informação na mensagem transmitida, denominado "número de seqüência". O controle de seqüência, exemplificado na figura 5.7, é uma técnica de implementação da semântica "at most once" e nesse caso é deixado a cargo do usuário garantir a integridade dos dados, caso ocorra falha do servidor durante a execução de uma primitiva.

Para que seja efetuada a primeira requisição, o servidor assume que o cliente fará uma solicitação com número de controle de seqüência igual a zero. Ao receber a requisição o servidor compara o número da seqüência recebida com o valor esperado e 
constatando serem iguais, este executa a primitiva, armazena o resultado da execução, complementa o número de seqüência e transmite a resposta com o número de seqüencia original. O cliente ao receber o resultado da execução da primitiva, complementa 0 número de seqüência entrando novamente em sincronismo com o número esperado pelo servidor. Caso ocorra algum problema e o cliente efetue mais de uma vez uma mesma requisição, cabe ao servidor verificar o número de seqüência e retransmitir o valor do resultado previamente armazenado [AN93].

Cliente

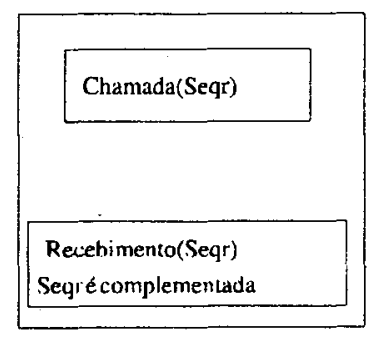

Servidor

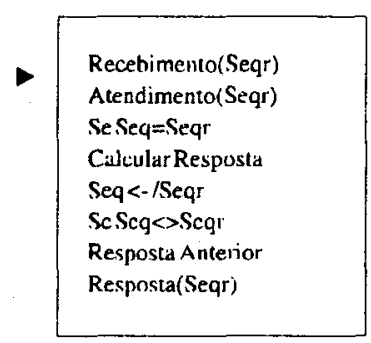

Fig 5.7 - Seqüência de Requisições

É previsto nas variáveis necessárias, um campo para se armazenar essa resposta da execução da primitiva. No servidor as variáveis são as seguintes:

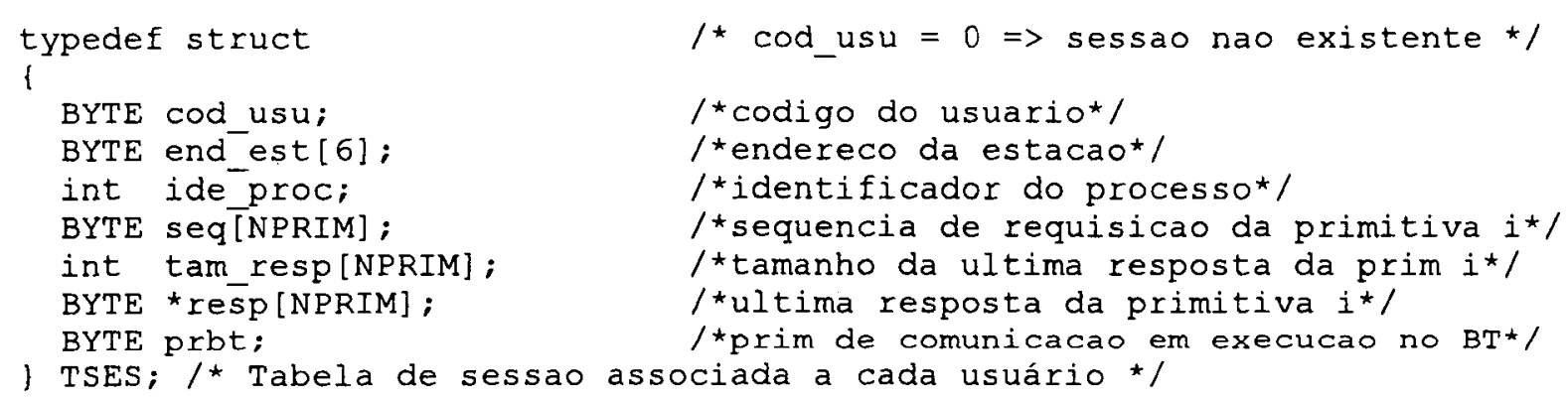

localizadas no arquivo de definições globais. No arquivo inics.h, são declaradas e iniciadas variáveis relacionadas com a resposta de cada primitiva: (exemplo para duas primitivas)

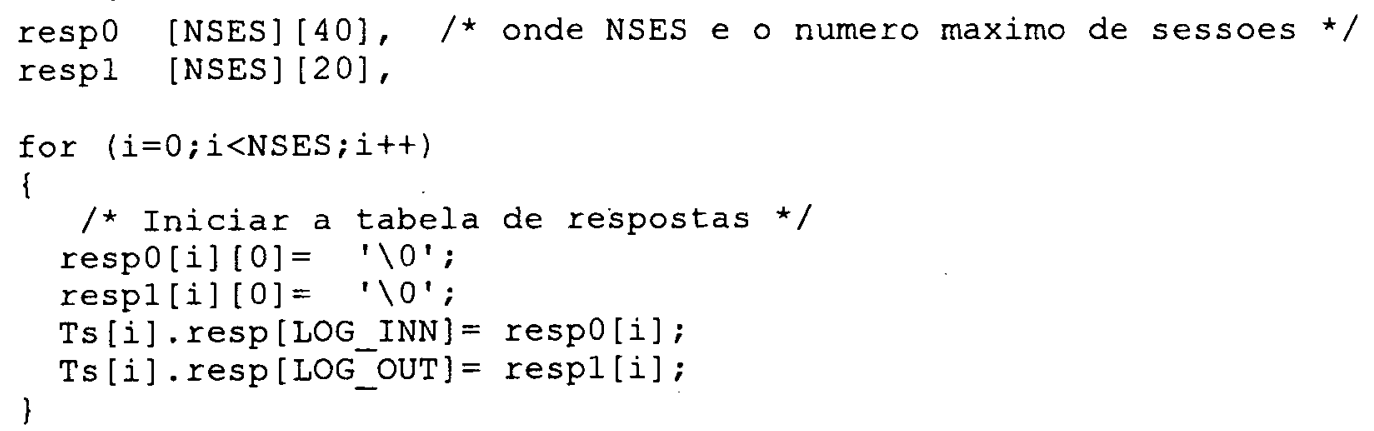


O módulo AtenderprocedimentoRemoto, do arquivo sts.c, que implementa o mecanismo de controle de seqüência, antes de enviar a resposta para o cliente, armazena a resposta na tabela de sessão e complementa a seqüência:

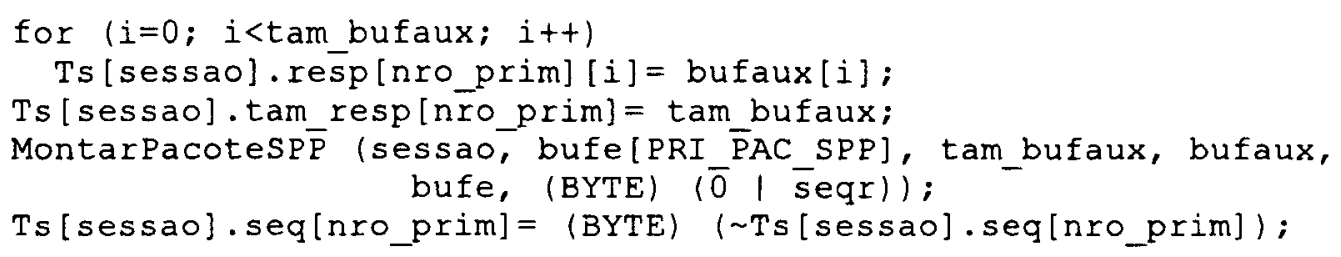

O módulo processarSPP, que verifica a possibilidade de execução da primitiva solicitada, além de verificar, entre outras coisas, se a primitiva existe, se o usuário tem permissão para utilizá-la, se a sessão associada ao usuário existe, verifica também se o pacote é uma requisição nova ou se era um pedido repetido (com o mesmo número de seqüência), para poder assim decidir no módulo superior(o AtenderProcedimentoRemoto) se chama uma nova primitiva ou se simplesmente envia a resposta anterior.

No software da estação, a tabela de usuário tem um campo relacionado com o número da sequiência, de acordo com a estrutura abaixo:

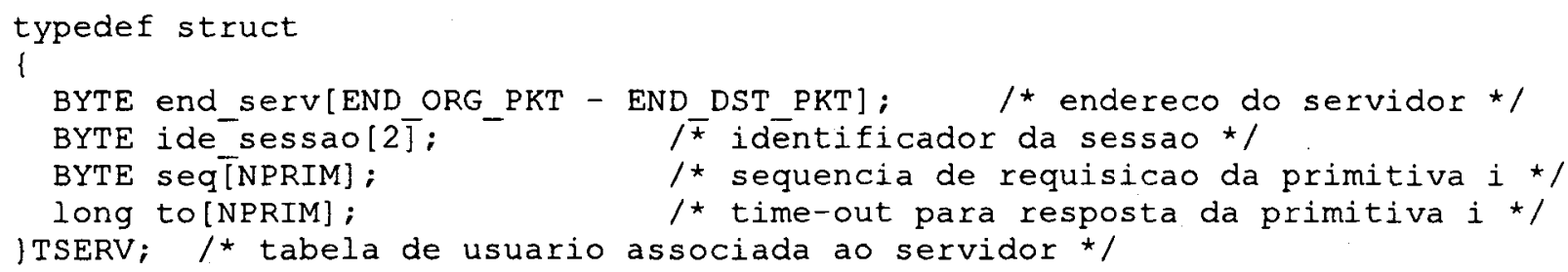

Ao ser executada uma das primitivas, a sequência de requisição é complementada da seguinte maneira:

/*complementa a sequencia a cada nova chamada*/

Ts [servidor].seq[LOG_OUT] $=$ (BYTE) ( Ts[servidor].seq[LOG_OUT] $)$;

onde LOG_OUT é o número associado à primitiva.

$\mathrm{Na}$ implementação da semântica "at-least-once", não é necessário que exista nenhum mecanismo para controle do número de vezes que as primitivas são executadas. Conseqüentemente as estruturas de dados relacionadas com o mecanismo do número de seqüência foram eliminadas, ficando da seguinte maneira:

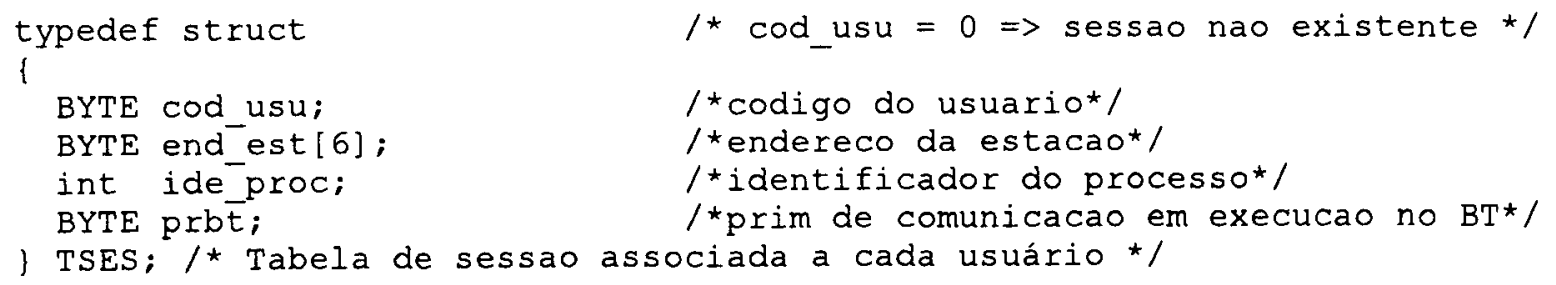


As variáveis relacionadas com o armazenamento das respostas, foram eliminadas do arquivo inics. $\mathrm{h}$.

O módulo AtenderProcedimentoRemoto executa a primitiva solicitada e envia a resposta sem armazená-la previamente.

O módulo ProcessarSPP verifica a possibilidade de execução da primitiva, só que não faz mais o teste do número de seqüência.

O programa iniseq.exe, responsável por iniciar todas as sequiências com 0 (zero) passou a não fazer sentido nessa nova implementação do protocolo.

No software da estação a estrutura de dados relacionada à associação usuárioservidor passou a ser:

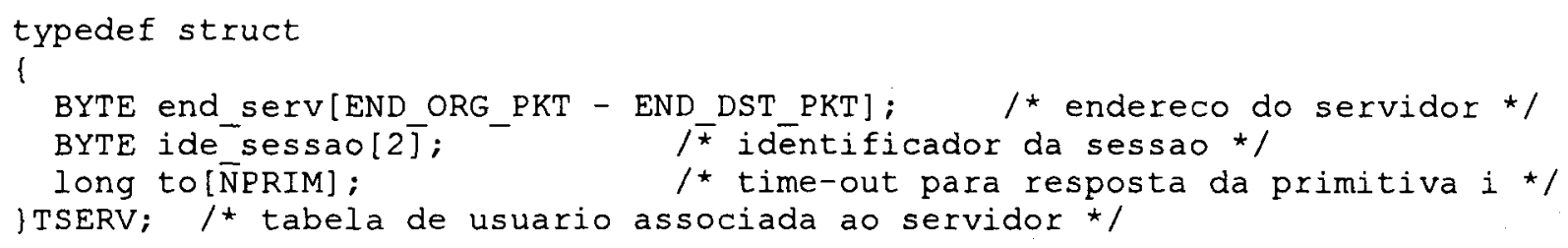

tendo sido eliminadas as complementações de seqüência no final de cada primitiva executada.

No capítulo 7 são apresentados os resultados obtidos com as alterações acima descritas. É apresentado também uma análise estatística desses resultados.

O mecanismo RPC [AN91] foi implementado segundo uma estrutura hierárquica organizada em camadas, análoga ao modelo ISO-OSI [TA89], apesar desse modelo não considerar o mecanismo de RPC.

\begin{tabular}{|c|c|c|}
\hline APLICAÇ.ĀO & ISERVER & OUTROS \\
\hline APRESENTACÃO & ASP & APLICATIVOS \\
\hline SESSÃO & \multicolumn{2}{|c|}{$\begin{array}{l}\checkmark S P P \\
\text { TRATAMENTO RPC } \\
\text { SPP }\end{array}$} \\
\hline TRANSPORTE & RECEPCÃO & TRANSMISSÃO \\
\hline REDE & $\begin{array}{l}\text { PKT } \\
\uparrow P K T\end{array}$ & PKT \\
\hline DADOS (LLC) & $\downarrow$ ETH & KTDRV (NCSA) \\
\hline \multirow{2}{*}{ (MAC) } & \multicolumn{2}{|c|}{ INTERFACE } \\
\hline & \multicolumn{2}{|c|}{ ETHERNET } \\
\hline
\end{tabular}

-Estaçüo -

APLICAÇÃo
APRESENTAÇÃo
SESSÃo
TRANSPORTE
REDE
DADOS (LLC)
MEIO FÍSICO

\begin{tabular}{|c|c|}
\hline \multicolumn{2}{|c|}{ IMPI.FMENTAÇĀO } \\
\hline \multicolumn{2}{|c|}{ DAS PRIMITIVAS } \\
\hline \multicolumn{2}{|c|}{$\begin{array}{l}\text { TRATAMENTO RPC } \\
\text { SPP }\end{array}$} \\
\hline \multicolumn{2}{|l|}{$\checkmark \mathrm{PKT}$} \\
\hline RECEP & TRANSM \\
\hline $\begin{array}{l}\text { PKT } \\
\text { P PKT }\end{array}$ & $\overline{\mathrm{PKT}}$ \\
\hline \multicolumn{2}{|c|}{$\begin{array}{l}\text { ETH } \\
\text { PKTDRV (NCSA) }\end{array}$} \\
\hline \multicolumn{2}{|l|}{ INTERFACE } \\
\hline \multicolumn{2}{|l|}{ ETHERNET } \\
\hline
\end{tabular}

-Servidor -

Fig. 5.8 - Estrutura em Camadas do Software Correlação com o modelo ISO-OSI 
A figura 5.8 mostra a correlação existente entre as camadas previstas no modelo ISO-OSI $\mathrm{e}$ as camadas implementadas neste sistema. A interface Ethernet está implementada até a subcamada MAC ("Medium Access Control") da camada de dados. A camada de rede e transporte não foram implementadas pois não houve necessidade das funções ali previstas. Em versões futuras do sistema, com a utilização de outras linguagens e aplicativos, pode surgir a necessidade da implementação da camada de transporte para possibilitar a transferência de pacotes de dados maiores que os permitidos pela camada de dados [TR91]. O mecanismo RPC foi implementado na camada de sessão, conforme sugere [TA89]. As primitivas e aplicativos foram implementados em camada mais elevada, englobando as camadas de apresentação e aplicação do modelo ISO-OSI.

Para efetuar a implementação da semântica "at-least-once" e das outras alterações descritas no item anterior foram modificadas praticamente todas as camadas do software.

Seguindo a figura 5.8 percebe-se que foram executadas as seguintes alterações:

- camada de aplicação e apresentação:

- inclusão de mecanismo de cadastramento de usuários,

- alteração das variáveis relacionadas com o armazenamento da resposta e com o controle de seqüência.

- camada de sessão:

- modificação das rotinas que implementam o mecanismo de controle de seqüência, especialmente os módulos AtenderProcedimentoRemoto e ProcessarSPP.

- camada de dados:

- alteração das rotinas escritas em assembly para Turbo-C.

\subsection{Considerações Finais}

O Servidor de Processamento Paralelo (SPP) é um sistema que continuará em constante evolução, requerendo sempre estudos pormenorizados para que as mudanças a serem efetuadas sejam bem fundamentadas.

Com a revisão do projeto do sistema SPP realizada neste capítulo teve-se o objetivo de se fechar alguns pontos que ficaram em aberto na implementação original do sistema.

Um outro ponto atingido com a revisão feita neste trabalho foi o aprimoramento da documentação do sistema SPP. Com as rotinas escritas em C, ao invés de "assembly", a 
documentação fica mais acessivel para que qualquer pessoa possa entender mais facilmente o funcionamento do SPP facilitando futuras alterações.

Com o estudo e a revisão do SPP, realizados neste capítulo, obteve-se como produto a evolução do protocolo previamente desenvolvido. Como conseqüência uma discussão mais detalhada e documentada do funcionamento do protocolo SPP.

No próximo capitulo será discutida a utilização do protocolo do sistema SPP em um ambiente TCP/IP. Para isso é descrito o ambiente utilizado para esta implementação, bem como as alterações necessárias para que seja viável a utilização do protocolo TCP/IP para se ter acesso ao Banco de Transputers. 


\section{Capítulo 6}

\section{Utilização do Protocolo TCP/IP no Ambiente SPP}

A decisão de se utilizar o protocolo TCP/IP para se ter acesso ao sistema SPP à partir desse protocolo foi motivada pela abrangência de uso do conjunto de protocolos TCP/IP.

A utilização do protocolo TCP/IP para esse fim (acesso ao sistema SPP) não é uma tarefa fácil de se realizar. A implementação desse conjunto de protocolos é complicada e aliado ao fato do software do SPP ser também de grande complexidade o desenvolvimento desta etapa foi bem trabalhosa.

Neste capítulo são apresentadas algumas justificativas do porquê de se utilizar esse protocolo. É apresentado o sistema Ka9Q, que foi utilizado para a implementação do sistema e são apresentadas as dificuldades encontradas no decorrer do trabalho, detalhes das modificações e da implementação do sistema em estudo.

\subsection{Disponibilidade/Flexibidade da Utilização do SPP em função de um protocolo mais difundido}

O conjunto de protocolos TCP/IP se tornou, de fato, o padrão para a interconexão de sistemas abertos na indústria de computadores. A maioria dos sistemas de computação utilizam os protocolos TCP/IP para se comunicar, pois estes fornecem um alto grau de interoperabilidade, engloba grande parte dos sistemas vendidos e pode ser executado sobre várias tecnologias de rede [CO91]. Instituições de pesquisa e de educação têm utilizado os protocolos TCP/IP como sua plataforma primária de comunicação.

Além do uso convencional, como visto no capítulo 3, os protocolos TCP/IP são utilizados também para se comunicar através da Internet, fazendo com que pesquisadores troquem informações e pesquisas mais rapidamente.

O pacote Internet Ka9Q [KA91] é uma implementação da família de protocolos TCP/IP, sendo o resultado de vários anos de desenvolvimento. $\mathrm{O}$ grupo de usuários dos 
protocolos TCP/IP cresceu e hoje em dia inclui membros de todo o mundo, sendo que muitos deles contribuiram com idéias e com trabalho para o desenvolvimento e implementação do pacote Ka9Q. O Ka9Q é um pacote de dominio público, disponivel a partir da UUNET Technologies Inc, Falls Church, Virginia, via "ftp anonymous".

O programa net (versão executável do Ka9Q) implementa um sistema operacional multi-tarefas, que fornece suporte para programação concorrente, dando a ilusão, em máquinas com um único processador, de que vários programas possam ser executados simultaneamente.

O compilador utilizado para gerar a versão executável (o programa net.exe) é o Turbo-C v.2.0 e o TASM v.1.0. Para se ter um bom funcionamento e uma compilação bem sucedida é aconselhável que a máquina tenha 4MBytes de memória RAM.

Para a instalação do ambiente TCP/IP é necessária a configuração adequada dos arquivos (descritos em 6.3.1). Assim para se ter um ambiente de desenvolvimento adequado, foram considerados três microcomputadores, dedicados a este projeto, e o ambiente de desenvolvimento obtido é mostrado na figura 6.1.

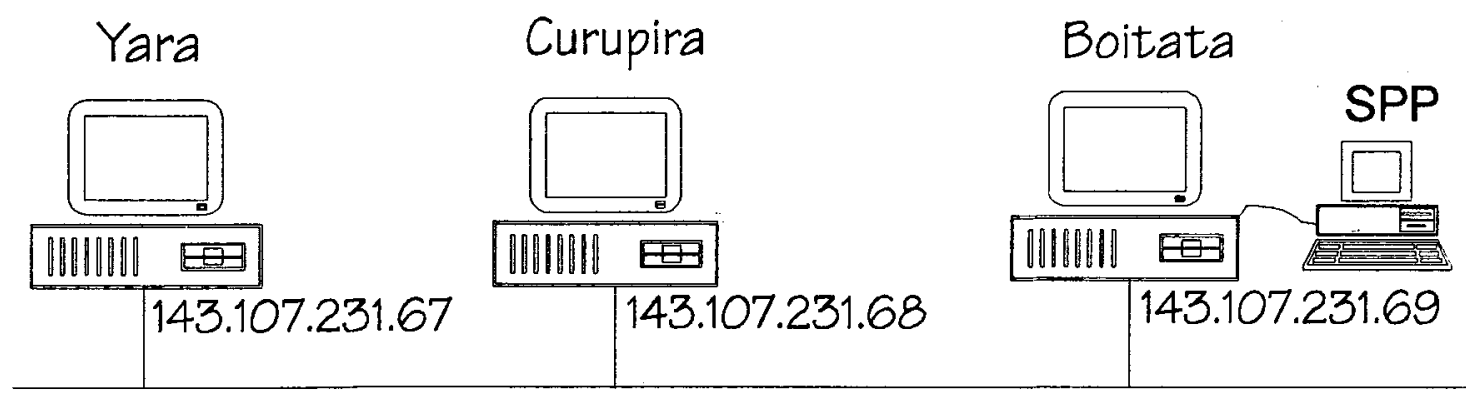

Fig. 6.1 - Ambiente de desenvolvimento

\subsection{O Programa net.exe}

Com a execução do programa net.exe (dentro do ambiente MS-DOS) é possivel se ter acesso a recursos da Internet (TCP/IP, NET/ROM e AX25). O net.exe implementa um núcleo multi-tarefas, podendo se comportar como um cliente (por exemplo quando se executa o ftp em uma máquina remota), um servidor (quando se atende a uma solicitação de $\mathrm{ftp}$ gerada remotamente) ou ainda um roteador de pacotes (quando é recebido um pacote não TCP/IP, mas que o sistema conhece o destino).

A configuração do ambiente gerado pela execução do net.exe, pode ser definida tanto através dos arquivos de configuração (descritos ainda neste item), como através de 
intervenção via teclado. Nesse caso o operador local tem controle sobre todo o ambiente, podendo alterar as interfaces acopladas ao sistema, os caminhos de roteamento, mudar o tamanho dos "buffers" de mensagens, etc.

Para utilização dos recursos do TCP/IP, NET/ROM e AX25, dentro do ambiente criado por net.exe, tem-se os serviços descritos na tabela 6.1 .

\begin{tabular}{|c|c|}
\hline - telnet: & $\begin{array}{l}\text { O protocolo telnet, como implementado no software Ka9Q, permite } \\
\text { que os usuários se comuniquem via uma conexão de teclado. }\end{array}$ \\
\hline - mail: & $\begin{array}{l}\text { O protocolo para transferência de mail (SMTP - Simple Mail Transfer } \\
\text { Protocol) fornece serviços para enviar e receber mails. }\end{array}$ \\
\hline $\begin{array}{l}\text { - Tranferência } \\
\text { de arquivos: }\end{array}$ & $\begin{array}{l}\text { O protocolo para transferência de arquivos (FTP) permite que um } \\
\text { usuário em um computador qualquer (cliente), copie ou envie } \\
\text { arquivos para um outro computador (servidor). A segurança é } \\
\text { controlada através do nome e da senha para se ter acesso ao outro } \\
\text { computador. }\end{array}$ \\
\hline - Serviços ax25: & São fornecidos também os serviços regulares AX.25. \\
\hline - NET/ROM: & $\begin{array}{l}\text { O sistema net permite também que o sistema sirva como um nó } \\
\text { NET/ROM. }\end{array}$ \\
\hline
\end{tabular}

Tabela 6.1 - Serviços Disponíveis no Sistema net

Para acesso aos serviços listados na tabela 6.1, bem como outros serviços adicionais, também disponiveis através do net.exe, existem diversos comandos, descritos na documentação geral do pacote Ka9Q [KA91].

No próximo sub-item são apresentados os arquivos de configuração do ambiente gerado pelo programa net.

\subsubsection{Arquivos de Configuração do Programa net}

O ambiente gerado pelo programa net pode ser configurado através de parâmetros fornecidos em diversos arquivos. 


\section{- O Arquivo AUTOEXEC.NET}

O arquivo AUTOEXEC.NET (às vezes chamado de STARTUP.NET, por exemplo no sistema Unix) funciona como o arquivo AUTOEXEC.BAT no DOS (por isso a semelhança do nome). Quando o programa net é executado, ele lê o arquivo AUTOEXEC.NET e executa todos os comandos existentes, como se eles tivessem sido passados para o programa via teclado. Esse é um mecanismo fácil para se definir a configuração inicial do sistema, incluindo o nome do host, os parâmetros AX.25, interfaces usadas, servidores a serem disparados e variáveis do protocolo em geral.

O arquivo do sistema em estudo tem a seguinte configuração:

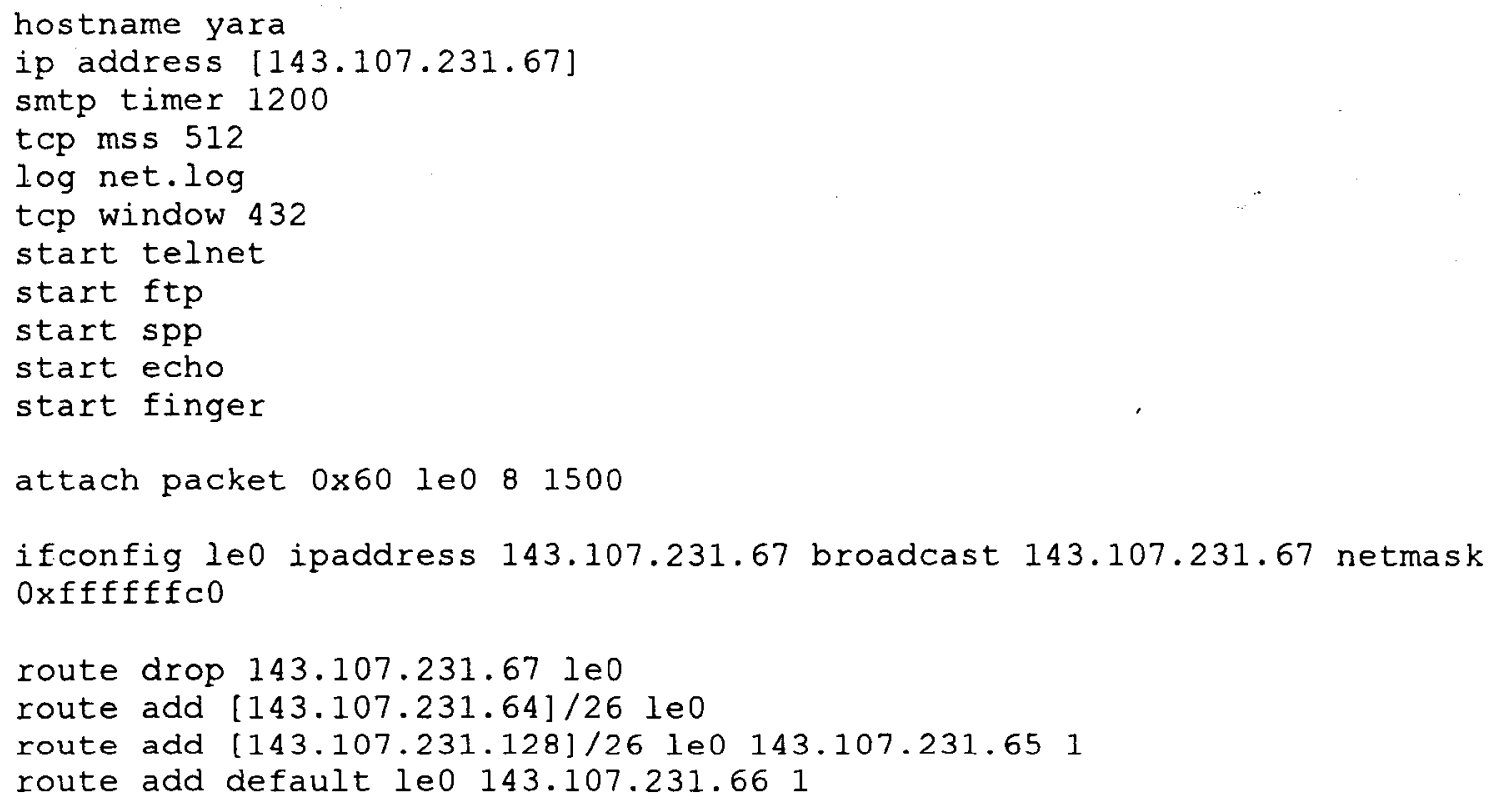

\section{- O Arquivo FTPUSERS}

Como o sistema DOS foi projetado para ser um sistema operacional mono-usuário, ele não fornece controle de acesso aos arquivos e eles podem ser eliminados, copiados ou modificados pelo usuário local. Não é uma boa política permitir que usuários remotos em um sistema baseado em rede tenham todos esses privilégios.

O arquivo "/FTPUSERS" (localizado na máquina servidora) é usado para controlar o acesso remoto de FTP. Se por um acaso a máquina servidora não possuir esse arquivo, o servidor FTP não poderá ser utilizado. Um usuário remoto deve primeiro executar um login ao sistema, dando um nome e uma senha (que devem estar nesse arquivo), para que 
possa fazer qualquer transferência de arquivos. O arquivo "/FTPUSERS" também é utilizado para o controle de acesso ao SPP. formato:

Cada entrada do arquivo "/FTPUSERS" consiste em uma linha com o seguinte username password pathl permissions 1 path2 permissions $2 \ldots$

devendo existir exatamente um espaço entre um campo e outro e as linhas de comentários começam obrigatoriamente com um "\#" na coluna 1.

\begin{tabular}{|c|c|}
\hline "username" & E o nome de login do usuário. \\
\hline "password" & $\begin{array}{l}\text { É a senha associada ao nome do usuário. Se for um "*" ( um } \\
\text { asterisco) qualquer senha é aceita. }\end{array}$ \\
\hline "/pathN" & Caminho a partir do qual se tem permissão. \\
\hline "permissionsN" & $\begin{array}{l}\text { É um número decimal especificando qual a permissão para } \\
\text { acesso aos arquivos. } \\
\text { Se o bit menos significatico }(0 \times 1) \text { for colocado em } 1 \text {, o usuário } \\
\text { tem permissão de leitura.. } \\
\text { Se o próximo bit }(0 \times 2) \text { for colocado em } 1 \text {, a permissão é de se } \\
\text { criar um novo arquivo, desde que não sobre-escreva um que já } \\
\text { exista. } \\
\text { Se o terceiro bit }(0 \times 3) \text { for colocado em } 1 \text {, o usuário pode } \\
\text { escrever, mesmo que já exista um arquivo com o mesmo nome e } \\
\text { ainda pode apagar arquivos. }\end{array}$ \\
\hline
\end{tabular}

Tabela 6.2 - Linha de Entrada do Arquivo "/FTPUSERS"

Segue abaixo um exemplo de configuração para o arquivo "/FTPUSERS".

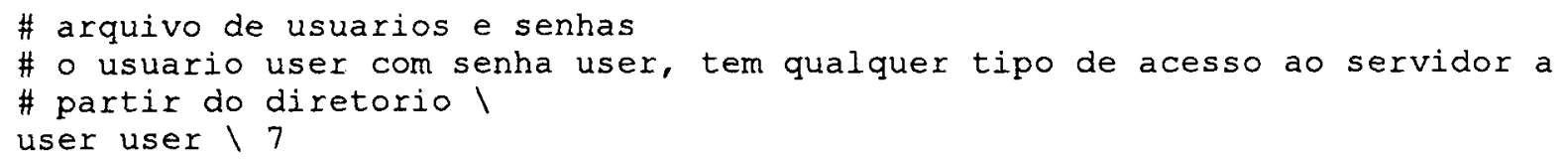

\section{- O Arquivo HOSTS.NET}

O Arquivo HOSTS.NET fornece um mapeamento entre os endereços Internet e os nomes simbólicos dos hosts. É usado pelo programa net para descobrir qual endereço IP 
usar a partir do nome do host.

A seguir é apresentado um exemplo desse arquivo para o ambiente de desenvolvimento utilizado neste trabalho:

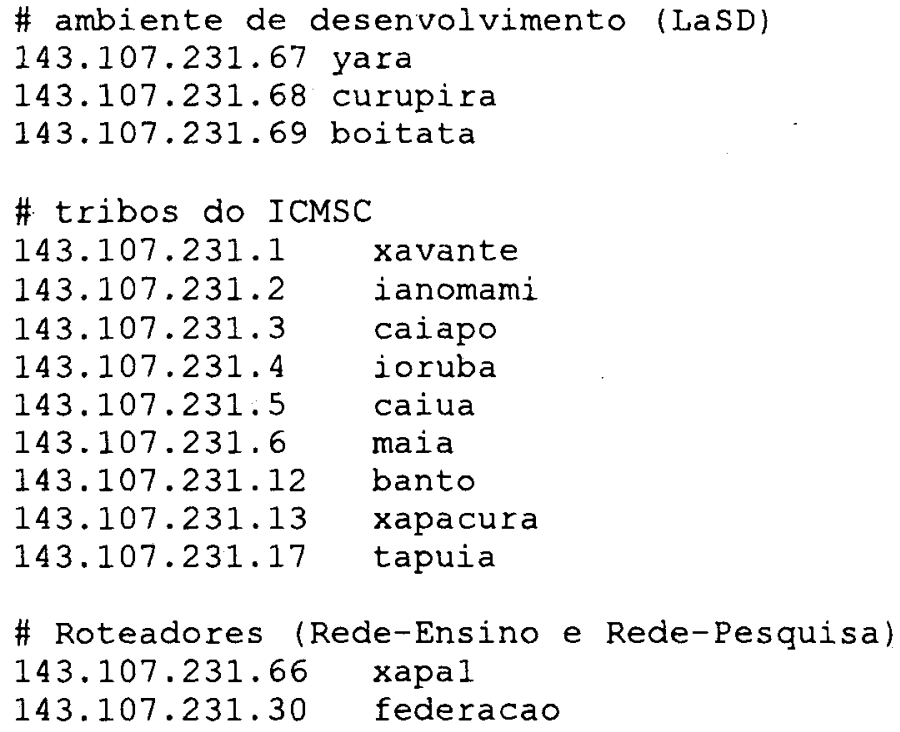

\subsection{Projeto Lógico}

A implementação do pacote Ka9Q é altamente modular e seguindo a estrutura mostrada na tabela 6.3 , pode-se analisar as funções de cada módulo do sistema.

\begin{tabular}{|c|c|}
\hline Clientes/Servidores & $\begin{array}{l}\text { Esse módulo implementa os clientes e os servidores dos } \\
\text { serviços descritos abaixo. }\end{array}$ \\
\hline Internet & $\begin{array}{l}\text { Nessa camada são implementados o protocolos TCP, UDP, } \\
\text { IP, }\end{array}$ \\
\hline $\operatorname{ax} 25$ & \multirow[t]{2}{*}{ Os serviços AX25 e net/rom são aqui implementados } \\
\hline net/rom & \\
\hline $\begin{array}{l}\text { Protocolo } \\
\text { Ponto }\end{array}$ & $\begin{array}{l}\text { Funções relacionadas com a implentação do protocolo } \\
\text { ponto-a-ponto. }\end{array}$ \\
\hline net & $\begin{array}{l}\text { Camada intermediária dos aplicativos, as funções aqui } \\
\text { definidas são usadas para a implementação de novos } \\
\text { aplicativos. Os mecanismos de comunição (sockets) são } \\
\text { implementados nesta camada. }\end{array}$ \\
\hline Interfaces Físicas & $\begin{array}{l}\text { Implementa todo o suporte de hardware para as camadas } \\
\text { superiores. }\end{array}$ \\
\hline
\end{tabular}

Tabela 6.3 - Organização Lógica da Implementação do Programa net 
Para que os aplicativos tenham acesso ao protocolo de comunicação, o pacote Ka9Q implementa uma abstração chamada "socket", que é uma generalização do mecanismo de entrada e saída do Unix. Os "sockets" têm opções para vários tipos de redes, entre eles TCP/IP [CO91].

Para representar a hierarquia de chamadas no programa net, a figura 6.2 mostra um diagrama de estrutura modular simplificado. Note que o único módulo detalhado é o que trata do serviço ftp, isso porque, conforme mostra o sub-item 6.3.2, as alterações são efetuadas a partir desse módulo.

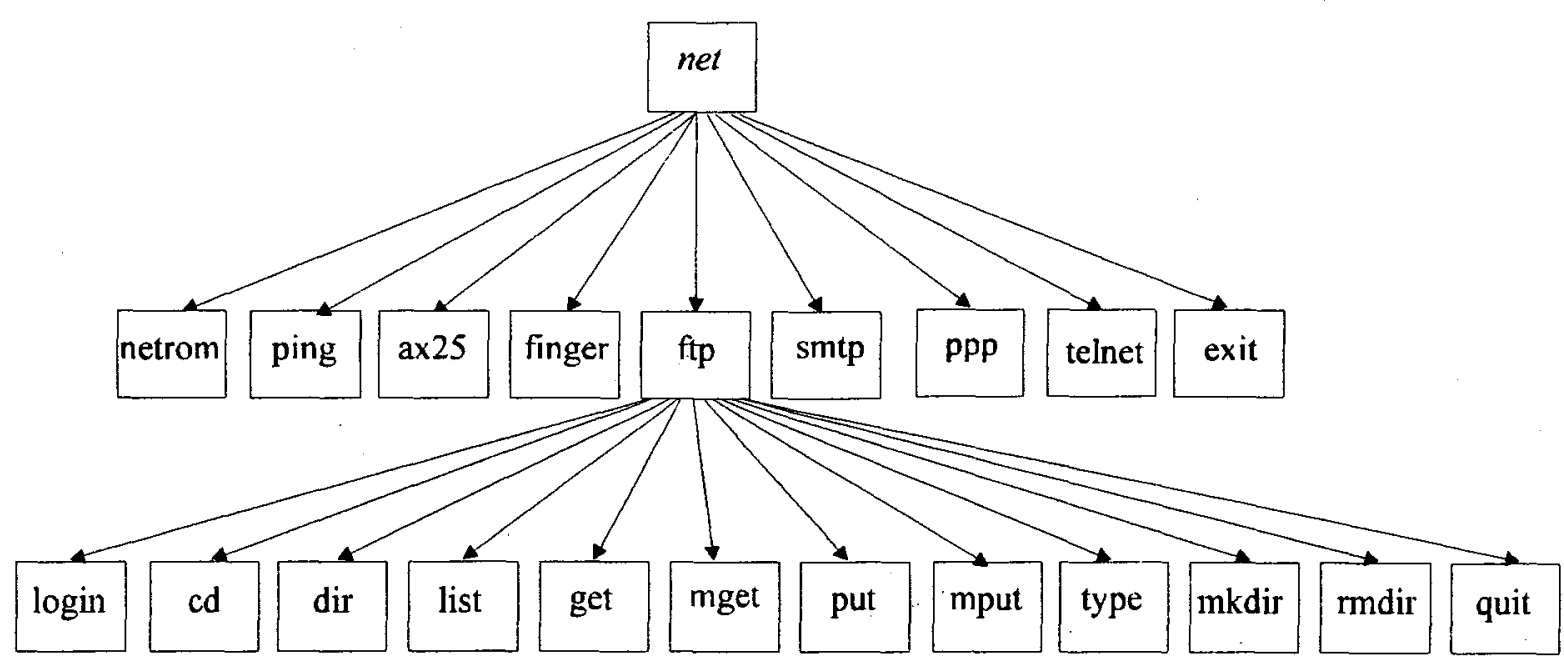

Fig. 6.2 - Diagrama de Estrutura Modular - Programa net

$\mathrm{Na}$ decisão de como se utilizar o programa net para se ter acesso ao sistema SPP foram encontrados alguns problemas. No próximo sub-item descrevem-se essas dificuldades e aponta-se qual a política adotada para a utilização do programa net.

\subsubsection{Dificuldades Encontradas}

A primeira abordagem dada para a utilização do protocolo TCP/IP foi a criação de uma biblioteca geral com todas as funções da implementação desse protocolo. A idéia inicial consistia em se utilizar apenas as rotinas do protocolo de comunicação. Essa abordagem foi abandonada, pois como o programa net implementa um sistema operacional multi-usuário, todas as funções das camadas superiores são necessárias para a criação do ambiente multi-tarefas. 
Numa segunda abordagem resolveu-se implementar as rotinas de comunicação com o sistema SPP no mesmo nível dos serviços fornecidos pelo programa net. Essa abordagem foi abandonada pois chegou-se à conclusão de que todo o tratamento de sessão e de conexão deveria ser feito para cada rotina separadamente.

Resolveu-se então criar um serviço disponível à partir do programa net, que fornece as primitivas necessárias para a comunicação com o banco de transputers. Dessa maneira o tratamento de sessão e de conexão é gerenciado por esse serviço criado, chamado spp (descrito no próximo item, juntamente com as modificações necessárias no programa net para a implementação desse serviço).

\subsubsection{Alterações Efetuadas no Programa net}

Para que o protocolo SPP fique disponível no programa net decidiu-se deixar o sistema SPP como mais um serviço oferecido pelo programa. Como mostra a figura 6.3 criou-se o serviço spp, à partir do qual ficam disponíveis as rotinas de comunicação com o banco de transputers.

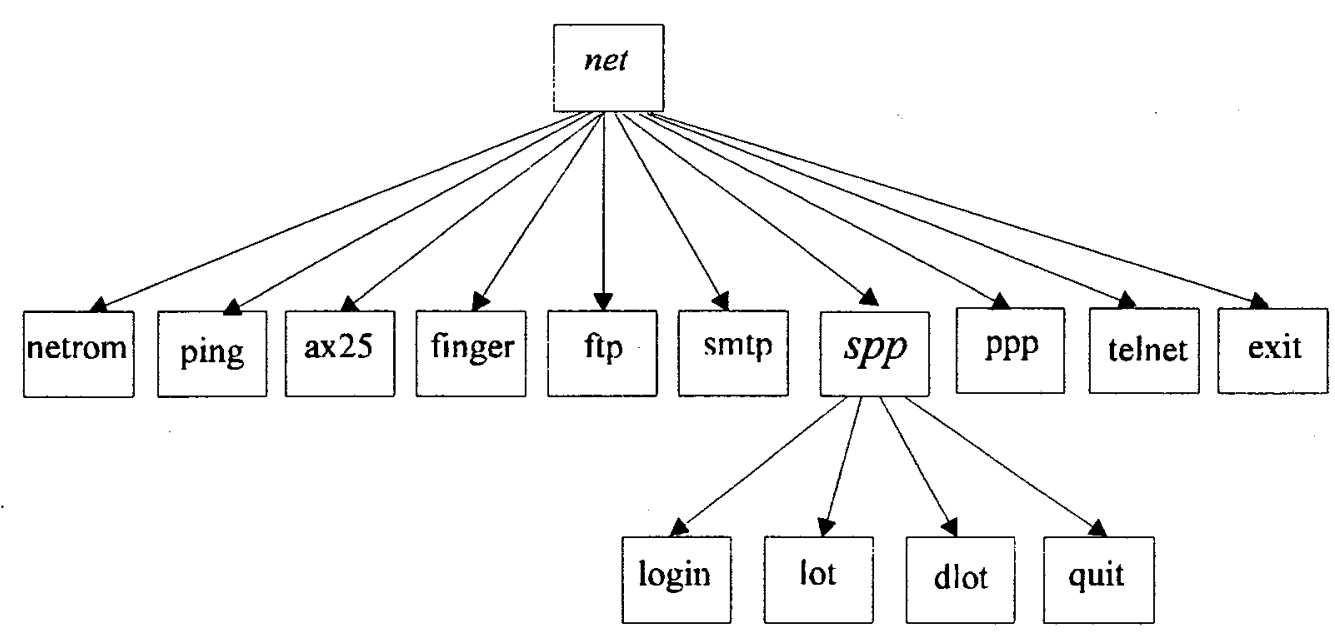

Fig. 6.3 - Diagrama de Estrutura Modular - Programa net modificado

Para ser ter acesso ao serviço spp, como a qualquer outro serviço fornecido pelo programa net, deve-se, na estação cliente, digitar o comando spp <endereço do servidor $>$, que no caso considerado é sempre o micro servidor, ligado ao Banco de Transputers. À partir desse comando será solicitado o nome do usuário e depois a sua senha. Os usuários (e suas respectivas senhas) devem estar cadastrados no arquivo "/FTPUSERS" da máquina servidora. As primitivas lot e dlot, descritas no apêndice A, 
foram implementadas utilizando a abstração de "sockets" para se comunicarem com o servidor.

\section{- Servidor}

A figura 6.4 mostra um diagrama de estrutura modular do software do servidor.

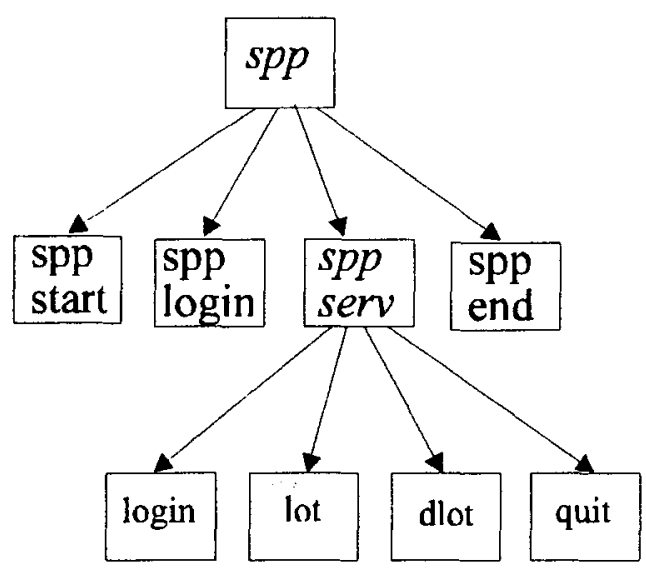

Fig. 6.4 - Diagrama de Estrutura Modular - Programa net (SPP - servidor)

No servidor é implementada uma rotina que inicia o servidor spp. Nela é criado o "socket" que fica aguardando a requisição de conexão de alguma estação. Assim que alguma estação solicita uma requisição, é disparado um outro processo, sppserv, que trata das primitivas implementadas. Vale lembrar que o programa Ka9Q pode estar executando outros serviços e ainda assim responder às solicitações da estação cliente.

O programa bt.t8, descrito no capítulo 5, não foi alterado. Ele sempre aguarda um pacote no formato SPP, então juntamente com cada primitiva implementada foram associados os procedimentos MontarPacoteSPF e DesmontarPacoteSPP.

\section{- Estação}

Na estação é implementada uma rotina, dospp, que cria o "socket" para fazer a conexão com o servidor. Depois de feita a conexão as primitivas estão disponíveis para o usuário. A figura 6.5 ilustra o diagrama de estrutura modular do cliente. 


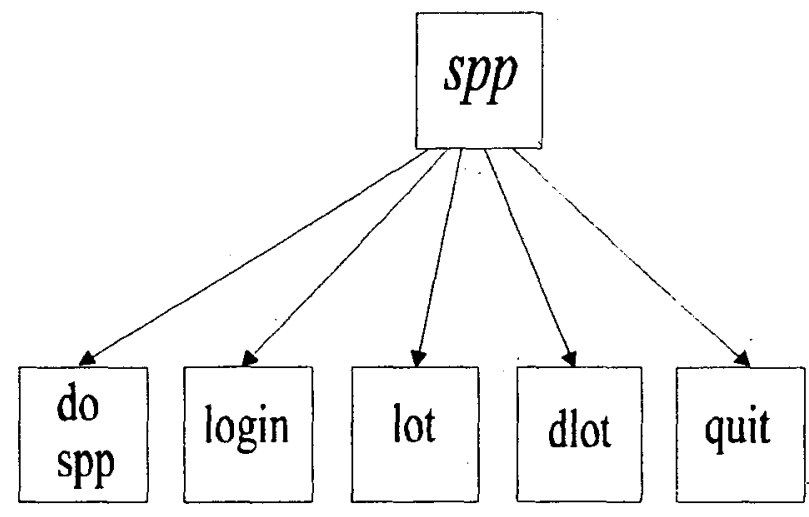

Fig. 6.5 - Diagrama de Estrutura Modular - Programa net (SPP - estação)

Tanto na estação quanto no servidor, o tratamento de sessão de trabalho, de manipulação dos pacotes e todos os detalhes relativos aos pacotes ethernet são tratados pelo programa net.

Todos os casos de teste: falha de comunicação com o Banco, não disponibilidade de lotes de transputers e outros, foram considerados na implementação.

\subsubsection{Utilização dos Transputers}

A idéia de se implementar o sistema SPP em ambiente TCP/IP é motivada pelo fato de que máquinas localizadas fora do escopo da rede do ICMSC-USP possam utilizar o Banco de Transputers. Nessa primeira implementação considera-se que o ambiente TDS não é viável para utilização a grandes distâncias e então o Banco de Transputers fica disponivel para aplicações que são desenvolvidas para executarem independentes do TDS, isto é, a partir do código objeto do programa gerado anteriormente.

Para a execução de um programa sobre uma rede de Transputers, independente do TDS, é necessário que esse programa seja carregado nas placas de Transputer. Uma das maneiras de se carregar o programa é com o auxílio de um computador hospedeiro conectado a rede.

O programa que permite que o computador hospedeiro carregue os programas no transputer e ofereça as facilidades de interface é o iserver. Nessa implementação o iserver considerado está localizado no servidor. Esse arquivo foi mais uma vez modificado para que as rotinas de comunicação com o Banco transmitam o pacote SPP conforme o Banco espera (item 6.3.2). As rotinas alteradas são as mesmas descritas no item 5.3.1 com o objetivo agora de comunicação do servidor com o Banco de Transputers. 
Um programa "standalone" que se comunica em tempo de execução com o iserver pode ser codificado de duas maneiras, descritas no documento [PA93b]. O código gerado em ambos os procedimentos é puramente binário, podendo ser migrado para qualquer hospedeiro que possua uma implementação do iserver.

Para se executar um programa "standalone" na versão do SPP para ambientes TCP/IP deve-se primeiro transferir o arquivo que será executado no Banco de transputers, via ftp, para a máquina servidora. Depois os passos são similares aos realizados para a execução do TDS.

- Abrir uma sessão (login)

- Alocar os processadores (lot)

- Executar o programa

Para se executar um programa standalone no SPP, foi desenvolvido um novo comando iserv que dispara o iserver (versão modificada) no servidor. Ao ser disparado $o$ iserver é executado o seguinte arquivo em lote:

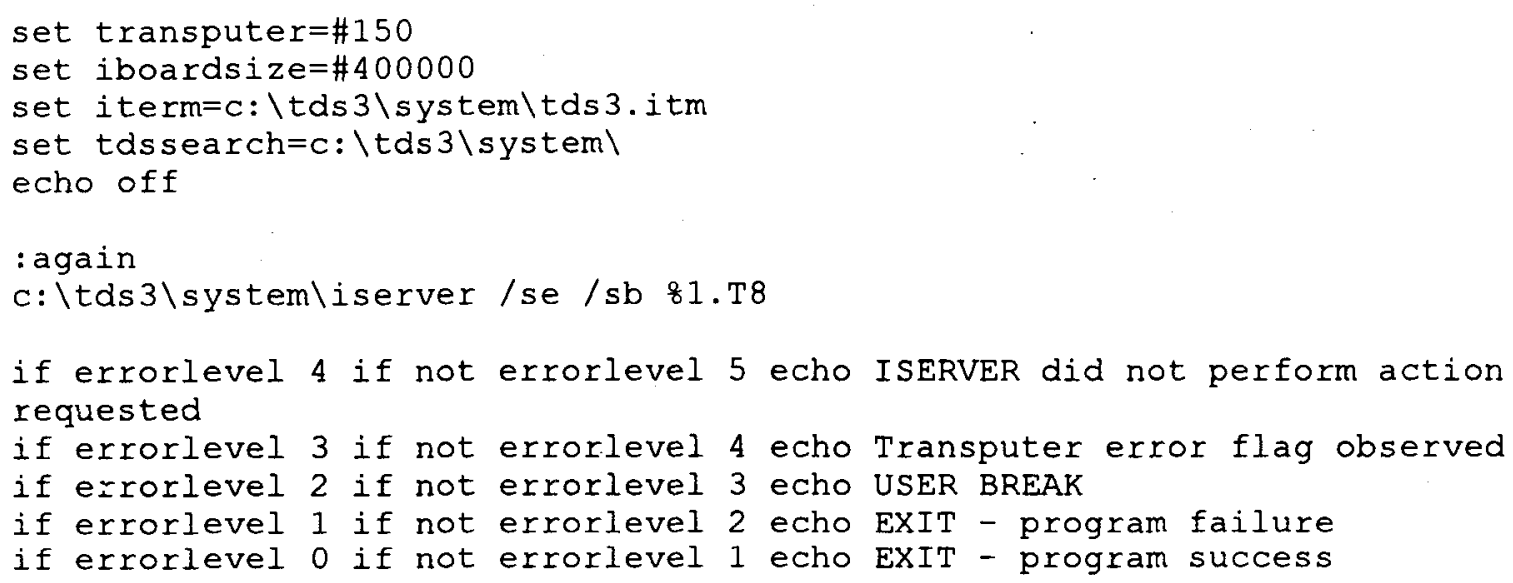

Depois de executado o programa, o usuário transfere, via $\mathrm{ftp}$, o arquivo com a saída do programa.

A geração de um programa "standalone" difere da geração e execução de programas a partir do TDS. Algumas bibliotecas especiais, que dão suporte ao uso do protocolo SP devem ser usadas: sphdr, splib, solib, sklib e spinterf [IN90].

\footnotetext{
Maiores detalhes sobre os tipos de programa standalone podem ser obtidos em [IN90].
} 


\subsection{Considerações Finais}

Como o conjunto de protocolos TCP/IP tem uma utilização altamente difundida a nível mundial, decidiu-se utilizá-lo para uma nova implementação do protocolo SPP, ficando como mais uma opção disponível (o sistema original não foi suprimido).

A maior parte das instituições de pesquisa utilizam o protocolo TCP/IP como plataforma de comunicação, assim a disponibilidade do sistema SPP utilizando esse conjunto de protocolos faz com que o sistema fique mais acessível. Além disso o sistema fica mais flexivel no sentido de ser incorporado a outros sistemas se for considerado o fato de que a maioria dos sistemas de computação utilizam os protocolos TCP/IP para se comunicar.

No próximo capitulo é feita uma análise dos resultados obtidos nas alterações do sistema original com a implementação da nova semântica de comunicação e dos resultados obtidos com a utilização dos protocolos TCP/IP. 


\section{Capítulo 7}

\section{Análise dos Resultados}

Para se observar quantitativamente quais foram os efeitos das modificações descritas nos capitulos anteriores sobre a implementação original do SPP, neste capítulo são apresentados os resultados obtidos, bem como efetuada uma análise desses resultados.

O objetivo dos testes realizados é comparar o tempo de execução das primitivas remotas nas duas semânticas que foram implementadas para a comunicação com o Banco de Tranputers - "at-least-once" e "at-most-once". Além de se fazer uma comparação com a versão implementada utilizando-se o TCP/IP.

\subsection{Técnica Utilizada para o Teste}

A análise dos resultados obtidos nos testes realizados foi feita pelo software estatístico SAS (Statistical Analysis System) versão 6.04, realizado no LAE (Laboratório de Estatística Aplicada) do departamento de Estatística da Universidade Federal de São Carlos.

A técnica utilizada para a comparação do tempo de execução das primitivas nas duas semânticas, "at-least-once" e "at-most-once", é o Teste t.

Realiza-se o seguinte teste de hipótese:

$$
\begin{aligned}
& H_{0}: \mu_{A T L}=\mu_{A T M} \\
& H_{I}: \mu_{A T L} \neq \mu_{A T M}
\end{aligned}
$$

onde: $\mu_{A T L}$ : tempo médio para a execução da variável em teste na semântica "at-leastonce", e once".

$\mu_{A T M}$ : tempo médio para a execução da variável em teste na semântica "at-most-

A estatística de teste se as variâncias são iguais é:

$$
t=\frac{\left(\bar{x}_{A T L}-\bar{x}_{A T M}\right)}{\sqrt{s^{2}\left(\frac{1}{n_{A T L}}+\frac{1}{n_{A T M}}\right)}}
$$

onde: $\overline{\mathbf{x}}_{\text {ATL }}$ : média amostral para a semântica "at-least-once" 
$\overline{\mathrm{X}}_{\mathrm{ATM}}$ : média amostral para a semântica "at-most-once"

$\mathrm{n}_{\mathrm{ATL}}$ : tamanho da amostra para a semântica "at-least-once"

$\mathrm{n}_{\mathrm{ATM}}$ : tamanho da amostra para a semântica "at-most-once

$s^{2}=\frac{\left[\left(n_{A T L}-1\right) s_{A T L}^{2}+\left(n_{A T M}-1\right) s_{A T M}^{2}\right]}{n_{A T M}+n_{A T L}-2}$

$\mathrm{S}^{2}{ }_{\text {ATL }}$ e $\mathrm{S}^{2}{ }_{\text {ATM }}$ : variância amostral para cada uma das semânticas.

Se as variâncias são diferentes a estatística de teste é:

$$
t^{\prime}=\frac{\bar{x}_{A T L}-\bar{x}_{A T M}}{\sqrt{\frac{\omega_{A T L}}{n_{A T L}}+\frac{\omega_{A T M}}{n_{A T M}}}}
$$

onde: $\bar{x}_{\text {ATL }}$ : média amostral para a semântica "at-least-once"

$\overline{\mathbf{x}}_{\text {ATM }}$ : média amostral para a semântica "at-most-once"

$\mathrm{n}_{\mathrm{ATL}}$ : tamanho da amostra para a semântica "at-least-once"

$\mathrm{n}_{\mathrm{ATM}}$ : tamanho da amostra para a semântica "at-most-once

$$
\begin{aligned}
\omega_{A T L} & =\frac{\sum\left(x_{i}-\bar{x}_{A T L}\right)^{2}}{n_{A T L}-1} \\
\omega_{A T M} & =\frac{\sum\left(x_{i}-\bar{x}_{A T M}\right)^{2}}{n_{A T M}-1}
\end{aligned}
$$

Verifica-se a igualdade das variâncias através da estatística:

$$
F^{\prime}=\frac{\max \left(s_{i}\right)}{\min \left(s_{i}\right)}
$$

correspondente ao teste de hipótese:

$$
\begin{aligned}
& H_{0}: \sigma_{1}=\sigma_{2} \\
& H_{1}: \sigma_{1} \neq \sigma_{2}
\end{aligned}
$$

$\mathrm{F}^{\prime}$ tem distribuição $\mathrm{F}-$ Snedecor com $\left(\mathrm{n}_{\mathrm{ATL}}, \mathrm{n}_{\mathrm{ATM}}\right)$ graus de liberdade. 
O valor $t$ é comparado com o valor tabelado e especificado por $n$ graus de liberdade $(n=$ tamanho da amostra $(A T L+A T M))$ e pelo nível de significância $\alpha . O$ valor escolhido para $\alpha$ foi 0.01 , isto é, permite-se errar em $1 \%$ das vezes.

Essa técnica estatística foi aplicada em dois casos de teste que serão apresentados no próximo item.

\subsection{Testes Realizados - SPP}

\subsubsection{Primeiro Teste Realizado}

O objetivo deste primeiro teste é analisar e comparar o tempo de transmissão relacionado a cada primitiva separadamente. Em todos os testes o tempo considerado é o tempo desde a chamada do procedimento remoto até a volta da requisição para a estação que fez a chamada.

Coleta dos Dados: Para coletar os dados para este teste, foi desenvolvido um programa na linguagem $\mathrm{C}$, que dispara cada uma das primitivas 1000 vezes. $\mathrm{O}$ procedimento foi $o$ mesmo para as duas semânticas em questão.

As primitivas consideradas no teste são login, lot, dlot e logout.

$\mathrm{Na}$ tabela 7.1 encontram-se os valores obtidos neste primeiro teste realizado, considerando a primitiva login.

\begin{tabular}{|c|c|c|c|c|}
\hline \multicolumn{5}{|l|}{ Primitiva Login } \\
\hline Semântica & $\mathbf{N}$ & Média (segs) & \multicolumn{2}{|c|}{ Desvio Padrão (segs) } \\
\hline ATL & 1000 & 0.02423075 & \multicolumn{2}{|c|}{0.00086312} \\
\hline ATM & 1000 & 0.02538459 & \multicolumn{2}{|c|}{0.00086668} \\
\hline \multicolumn{5}{|c|}{ Prob $>F^{\prime}=0.8966$} \\
\hline \multicolumn{2}{|c|}{ Variâncias } & \multicolumn{2}{|c|}{ gl } & Prob. $>$ t \\
\hline \multicolumn{2}{|l|}{$\neq$} & -0.9433 & 99 & 0.3457 \\
\hline \multicolumn{2}{|l|}{$=$} & -09433 & $\overline{998}$ & 0.3456 \\
\hline
\end{tabular}

Tabela 7.1 - Dados Obtidos para o Primeiro Teste - login

Para a primitiva login as variâncias são iguais e como a (prob $>t)>0.01$ (nível de significância escolhido) aceita-se a hipótese $\mathrm{H}_{0}$, isto é, a média de execução para a 
primitiva login nas duas semânticas é igual e não existe uma diferença estatisticamente significante entre as duas semânticas.

\begin{tabular}{|c|c|c|c|}
\hline & & & \\
\hline Semântica & $\mathbf{N}$ & Média (segs) & Desvio Padrão (segs) \\
\hline ATL & 1000 & 0.00093407 & 0.00710635 \\
\hline ATM & 1000 & 0.00252747 & 0.01151597 \\
\hline
\end{tabular}

\begin{tabular}{|c|c|c|c|}
\hline $\mathrm{F}^{\prime}=2.63$ & liberdad & 999) & $F^{\prime}=0.0000$ \\
\hline Variâncias & $\mathbf{t}$ & gl & Prob.>t \\
\hline$\not$ & -3.7236 & 999 & 0.0002 \\
\hline$=$ & -3.7236 & 1998 & 0.0002 \\
\hline
\end{tabular}

Tabela 7.2 - Dados Obtidos para o Primeiro Teste - logout

Considerando a primitiva logout, conforme mostra a tabela 7.2, as variâncias são diferentes (prob $\left.>F^{\prime}\right)<0.01$ e como a (prob $>$ t) $<0.01$ (nível de significância escolhido) rejeita-se a hipótese $\mathrm{H}_{0}$, isto é, a média de execução para a primitiva logout nas duas semânticas é diferente e existe uma diferença estatisticamente significante entre as duas semânticas.

As tabelas 7.3 e 7.4 representam os dados para as primitivas lot e dlot. Para essas primitivas as variâncias são diferentes $\left(\right.$ prob $\left.>F^{\prime}\right)<0.01$ e como a $($ prob $>t)<0.01$ rejeita-se a hipótese $\mathrm{H}_{0}$, isto é, a média de execução para as duas primitivas nas duas semânticas é diferente e existe um diferença estatisticamente significante entre as duas semânticas.

\begin{tabular}{|c|c|c|c|c|}
\hline \multicolumn{5}{|l|}{ Primitiva Lot } \\
\hline Semântica & $\mathbf{N}$ & Média (segs) & \multicolumn{2}{|c|}{ Desvio Padrão (segs) } \\
\hline ATL & 1000 & 0.00203297 & \multicolumn{2}{|c|}{0.01037670} \\
\hline ATM & 1000 & 0.09170320 & \multicolumn{2}{|c|}{0.03350342} \\
\hline \multicolumn{5}{|c|}{$\mathrm{F}^{\prime}=10.42 \mathrm{gl}($ graus de liberdade $)=(999,999)$} \\
\hline \multicolumn{2}{|c|}{ Variâncias } & $t$ & gl & Prob. $>t$ \\
\hline \multicolumn{2}{|l|}{$\neq$} & -80.8478 & 999 & 0.0000 \\
\hline \multicolumn{2}{|l|}{$=$} & -808478 & 1998 & 0.0000 \\
\hline
\end{tabular}

Tabela 7.3 - Dados Obtidos para o Primeiro Teste - lot 


\begin{tabular}{l||c||c||c||}
\hline Primitiva Dlot \\
\hline Semântica & N & Média (segs) & Desvio Padrão (segs) \\
\hline \hline ATL & 1000 & 0.00170330 & 0.00952770 \\
\hline ATM & 1000 & 0.09186804 & 0.03564389 \\
\hline $\mathrm{F}^{\prime}=14.00$ gl(graus de liberdade) $=(999,999)$ & Prob $>\mathrm{F}^{\prime}=0.0000$ \\
\hline
\end{tabular}

\begin{tabular}{|c||c||c||c||}
\hline Variâncias & $\mathbf{t}$ & $\mathbf{g l}$ & Prob.>t \\
\hline \hline$\neq$ & -77.2797 & 999 & 0.0000 \\
\hline \hline$=$ & -77.2797 & 1998 & 0.0000 \\
\hline
\end{tabular}

Tabela 7.4 - Dados Obtidos para o Primeiro Teste - dlot

Com os dados do teste descrito acima obtém-se o gráfico 7.1 que demonstra que no geral a semântica "at-least-once" é mais eficiente do que a semântica "at-most-once". A primitiva login gasta um tempo praticamente igual nas duas semânticas.

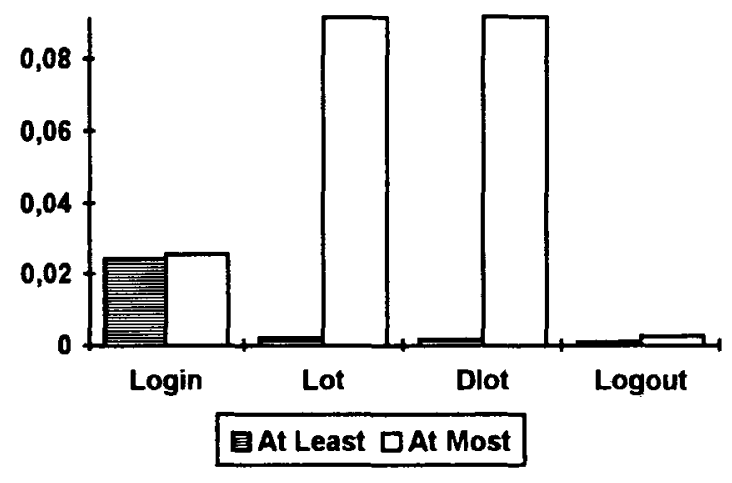

Gráfico 7.1 - Análise das Primitivas para o Primeiro Teste.

\subsubsection{Segundo Teste Realizado}

O objetivo deste teste é analisar e comparar o tempo gasto para se executar uma sessão mínima no banco de transputers. Isso significa o tempo de se entrar no sistema, alocar um lot, desalocá-lo e depois finalizar a sessão. O tempo considerado é o tempo desde a chamada do procedimento remoto até a volta da requisição para a estação que fez a chamada.

Coleta dos Dados: Para coletar os dados para este teste, foi desenvolvido um programa na linguagem $C$, que dispara as primitivas login, lot, dlot e logout 1000 vezes, respectivamente. $O$ procedimento foi o mesmo para as duas semânticas em comparação. 
A variável considerada neste teste é a soma do tempo de cada primitiva: login, lot, dlot e logout.

Sessão Mínima: Tempo de login+lot+dlot+logout

\begin{tabular}{|c||c||c||c|}
\hline Semântica & N & Média (segs) & Desvio Padrão (segs) \\
\hline ATL & 1000 & 0.02890107 & 0.03067268 \\
\hline ATM & 1000 & 0.21148331 & 0.05972045 \\
\hline
\end{tabular}

$\mathrm{F}^{\prime}=3.79 \quad \mathrm{gl}($ graus de liberdade $)=(999,999)$ Prob $>F^{\prime}=0.0000$

\begin{tabular}{|c||c||c||c|}
\hline Variâncias & $\mathbf{t}$ & $\mathbf{g l}$ & Prob. $>\mathbf{t}$ \\
\hline$\neq$ & -85.9999 & 999 & 0.0000 \\
\hline$=$ & -85.9999 & 1998 & 0.0000 \\
\hline
\end{tabular}

Tabela 7.5 - Dados Obtidos para o Segundo Teste - Sessão Mínima

$\mathrm{Na}$ tabela 7.5 encontram-se os valores obtidos neste teste realizado, considerando a sessão mínima.

Para a variável sessão mínima as variâncias são diferentes (prob $>F^{\prime}$ ) $<0.01$ e como a $($ prob $>\mathrm{t})<0.01$ rejeita-se a hipótese $\mathrm{H}_{0}$, isto é, a média de execução de uma sessão mínima nas duas semânticas é diferente e existe um diferença estatisticamente significante entre as duas semânticas.

O gráfico 7.2 mostra que o tempo médio de se executar uma sessão mínima na semântica "at-least-once" chega ser 0,18 segundos mais rápido do que na semântica ätmost-once".

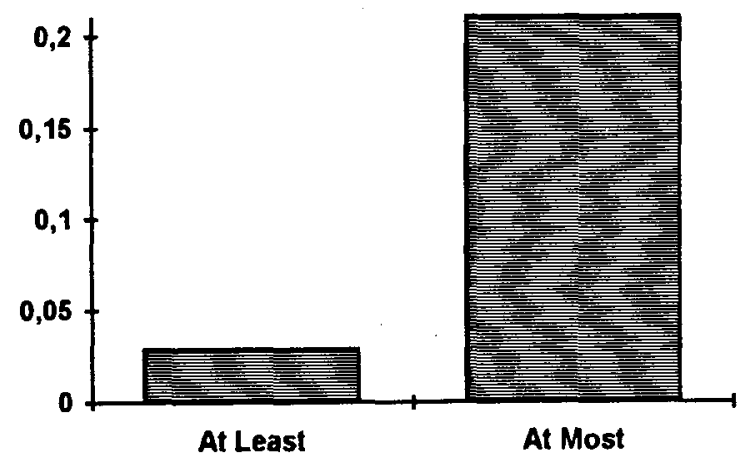

Gráfico 7.2 - Análise de uma Sessão Mínima para as duas Semânticas 


\subsection{Testes Realizados - Implementação TCP/IP}

$\mathrm{O}$ acesso ao SPP através dos protocolos TCP/IP é altamente interativo, dificultando a realização de testes quantitativos similares aos realizados nas versões discutidas anteriormente. Além disso, a implementação das primitivas para acesso ao Banco de Transputers na versão TCP/IP utiliza uma comunicação diferente da versão original do SPP. Na versão TCP/IP somente é transmitido o número da primitiva e o argumento para a primitiva, caso necessário, assim o método de comparação utilizado para as primitivas, discutido nos itens 7.1 e 7.2 não é adequado.

Assim para se fazer uma análise comparativa dos protocolos desenvolvidos com a implementação TCP/IP, criou-se uma primitiva, para efeito de teste, que na estação transfere arquivos para o servidor e no servidor simplesmente devolve um pacote de reconhecimento da recepção. A mesma implementação da primitiva foi utilizada para as três versões em comparação. Medindo-se o tempo de transferência dos arquivos, pode-se ter uma análise quantitativa da diferença de desempenho entre as três versões implementadas.

Para a execução do teste foram consideradas três faixas de tamanho de arquivos, conforme a tabela 7.6 :

\begin{tabular}{|l|c|}
\hline Pequenos & $0<$ Tamanho $<100 \mathrm{~KB}$ \\
\hline Médios & $100 \mathrm{~KB}<$ Tamanho $<1 \mathrm{MB}$ \\
\hline Grandes & $1 \mathrm{MB}<$ Tamanho $<$ máximo \\
\hline
\end{tabular}

Tabela 7.6 - Faixa de Tamanho de Arquivos para Teste

A tabela 7.7 apresenta os resultados obtidos, em segundos, no teste para cada tipo de arquivo:

\begin{tabular}{|l|c|c|c|}
\hline \multicolumn{1}{|c|}{ Tamanho } & 64143 Bytes & 526055 Bytes & 1050564 Bytes \\
\hline Protocolo & & & \\
\hline At-Most-Once & 0.4945 & 4.8175 & 9.7802 \\
\hline At-Least-Once & 0.3846 & 3.9714 & 7.6923 \\
\hline TCP/IP & 3.2967 & 28.768 & 57.637 \\
\hline
\end{tabular}

Tabela 7.7 - Resultados Comparativos com TCP/IP

Como pode-se observar pela tabela 7.7 e pelo gráfico 7.3 , a versão "at-least-once" é a implementação mais eficiente. 


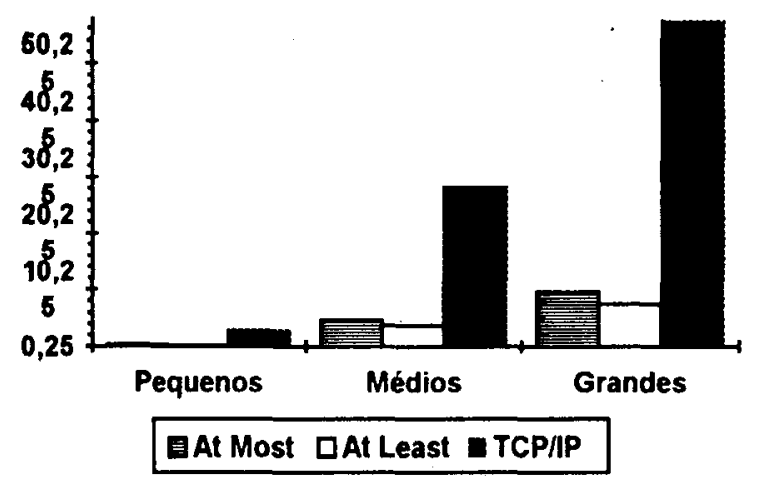

Gráfico 7.3 - Análise das Três Versões Implementadas

\subsection{Considerações Finais}

Os testes realizados na versão original do sistema SPP, com as duas semânticas implementadas, mostram que a semântica "at-least-once" é mais eficiente do que a semântica "at-most-once". Esse fato é justificado pela grande parte de código, responsável pelo controle de sequiência da semântica "at-most-once", que foi eliminada.

O usuário final deve decidir qual versão é mais adequada para o seu ambiente de desenvolvimento. Se ele pode garantir que a sua rede local possui alta confiabilidade de transmissão, e portanto baixa taxa de erros, a versão adequada a ser utilizada é a versão "at-least-once". Isso porque não se pode deixar de considerar o fato de que a versão "atleast-once" não garante uma única execução da primitiva e a repetição de uma mesma requisição pode causar o comprometimento do sistema, pois as primitivas do SPP não são idempotentes [WI87], isto é, se elas forem executadas mais de uma vez, o resultado está comprometido.

Os resultados obtidos com a implementação baseada no conjunto de protocolos TCP/IP sugerem que esta implementação deve ser utilizada em casos de acesso remoto ao SPP (isto é fora do ambiente LaSD) e que apesar da desvantagem observada em termos de desempenho, a utilização do Ka9Q deve ser, sempre que possível, incentivada para acesso remoto a ambientes computacionais.

No próximo capítulo são discutidas as dificuldades e as contribuições deste trabalho. Também são apresentadas sugestões para trabalhos futuros e as considerações finais. 


\section{Capítulo 8}

\section{Conclusão}

Nos capítulos anteriores foram apresentados os diversos aspectos relacionados com a revisão e ampliação do sistema SPP [TR91]. Foram discutidas duas propostas: a realização de uma nova semântica sobre o protocolo originalmente desenvolvido para o sistema e uma nova abordagem, baseada na utilização do conjunto de protocolos TCP/IP. Análises estatísticas visando quantificar o desempenho dos protocolos implementados foram realizadas e os resultados obtidos foram discutidos.

Neste capítulo apresentam-se as conclusões obtidas após a análise das atividades e resultados de cada uma das etapas do desenvolvimento deste trabalho. As principais dificuldades encontradas, as contribuições apresentadas por esta dissertação e sugestões para trabalhos futuros são discutidas. Nos comentários finais são avaliados os resultados obtidos, de acordo com os objetivos e a motivação inicialmente estabelecidos.

\subsection{Dificuldades Encontradas}

No decorrer do desenvolvimento deste trabalho foram encontradas diversas dificuldades de ordem prática que merecem ser destacadas.

Ao se migrar o software original do sistema SPP para o compilador Turbo-C versão 2.0 , o principal problema encontrado foi a grande diferença entre esse compilador e o Microsoft $C$ versão 6.0. Parte do tempo do projeto foi dedicado a esta etapa, visto que o sistema é relativamente grande e complexo.

Uma outra dificuldade encontrada foi na utilização de software de domínio público. A documentação disponível é normalmente precária e muitas vezes consiste unicamente no código fonte. Isso faz com que se leve um tempo excessivamente longo no entendimento do software, principalmente nos aspectos relativos à sua implementação. Não se pode, porém, deixar de salientar a importância dessa classe de software, uma vez que sua utilização permite reduzir em muito o esforço dispendido na implementação de novos sistemas.

As restrições de memória impostas pelo sistema MS-DOS foi outra dificuldade 
encontrada no desenvolvimento do projeto. Alguma modificação foi necessária para diminuir os requisitos de memória dos sistemas originais, possibilitando sua integração e execução sobre esse sistema operacional.

\title{
8.2 Contribuições Deste Trabalho
}

\author{
Algumas contribuições deste trabalho merecem destaque especial e são \\ relacionadas abaixo:
}

- Validação do software e algoritmos utilizados nos protocolos do sistema SPP original.

- Quantificação do desempenho do sistema de comunicação original, não realizada em [TR91].

- Implementação de uma semântica alternativa mais simples e eficiente ("at-least-once") para o núcleo RPC.

- Introdução do conjunto de protocolos TCP/IP, oferecendo maior versatilidade no acesso remoto ao sistema SPP.

- Extensão do acesso a transputers via "iserver", utilizando-se LANs.

- Domínio da tecnologia utilizada em sistemas baseados em processadores transputer.

\subsection{Trabalhos Futuros}

A atividade de pesquisa relacionada com as áreas de conhecimento associadas ao desenvolvimento do servidor de processamento paralelo estão em constante atualização. Outros trabalhos deverão ser realizados para que o SPP e sua documentação atendam às características desejáveis de fácil utilização e manutenção. São apresentadas a seguir algumas sugestões para trabalhos futuros.

- Adaptação do ambiente SPP para a execução de outros utilitários e linguagens de programação (hoje só está disponivel a linguagem OCCAM 2).

- Implementação de uma nova interface de programação que facilite o desenvolvimento de aplicações paralelas. 
- Desenvolvimento de ferramentas para a depuração dos programas paralelos.

- Instalação de software/hardware para monitoração, permitindo a otimização do desempenho do servidor e das aplicą̧ões sendo executadas no banco de transputers.

\subsection{Comentários Finais}

O sistema de processamento paralelo desenvolvido no LaSD foi revisado e ampliado seguindo as especificações iniciais do projeto [TR91], no sentido de que as idéias originais de se ter um recurso compartilhado para processamento paralelo, disponível eficientemente através de um sistema baseado em rede local, estão mantidas.

Manipular, alterar e expandir um sistema do porte do SPP não é uma tarefa trivial. Este trabalho serviu para exemplificar as dificuldades existentes e para incentivar cada vez mais a produção de documentação de bom nível, bem como a utilização de recursos que facilitem a fase de manutenção dos sistemas.

Os resultados obtidos com as novas implementações realizadas mostram que a versão original do SPP, embora não tenha sofrido uma bateria de testes exaustiva na ocasião da sua implementação, foi altamente bem sucedida.

As soluções alternativas propostas neste trabalho demonstram a possibilidade de se adotar semânticas mais rápidas para o núcleo RPC do sistema. Cabe ao usuário adequar a versão do protocolo ao ambiente disponível para a utilização do sistema. Os resultados e o desempenho adicional obtidos com a nova semântica serão de grande valia em implementações futuras e mais complexas no sistema SPP. 


\section{Referências Bibliográficas}

AN91 ANDRADE, A.L.P. Um Protocolo Dedicado para Acesso Remoto a Transputers via TDS - LASD - ICMSC- USP- Agosto, 1991

AN93 ANDRADE, A.L.P. Um Protocolo Dedicado para Acesso Remoto a Transputers via TDS. In: Congresso da SBC, 13., XX Semish, Florianópolis - SC, Agosto, 1993

BA87 BACON, J.M.; HAMILTON, K.G. Distributed Computing with RPC: The Cambridge Approach, Technical Report n. 117 - University of Cambridge, Outubro, 1987.

BA89 BAL, H.E.; STEINER, J.G.; TANENBAUM, A. S.; Programming Languages for Distributed Computing Systems; ACM Computing Surveys, Vol. 21, n. 3, Setembro, 1989.

BE89 BERSHAD, B.N.; ANDERSON, T.E.; LAZOWSKA, E.D.; LEVY, H.M. Lightweight Remote Procedure Call, Operating Systems Review, Special Issue, Vol. 23, n. 5, Dezembro, 1989.

BI84 BIRREL, A.; NELSON, B.J. Implementing Remote Procedure Calls. ACM Transactions on Computer Systems, Vol.2, n. 1, Fevereiro, 1984.

CH90 CHANDRAS, R.G. Distributed Message Passing Operating Systems, Operating Systems Review, Vol. 24, n. 1, Janeiro, 1990.

CL89 Clarkson University, THE PACKET DRIVER SPECIFICATION, User Documentation for the Packet Driver Collection. Version 1.09, US., 1989.

CO91 COMER, D. E.; STEVENS, D.L. Internetworking with TCP/IP Design, Implementation and Internal, Prentice Hall, Vol II, 1991.

CO91a COMER, D. E.; Internetworking with TCP/IP Principles, Protocols and Architecture, Prentice Hall, Vol I, 1991.

C088 COUlOURIS, F. G. and DOLlimORE, J. Distributed Systems Concepts and Design, Addison-Wesley Publishing Company; 1988. 
HO80 HOPPER, A.; The Cambridge Ring - A Local Network, in Harina, K.A. (ed), Advanced Techniques for Microprocessor Systems, Peter Peregrinus, 1980 .

IE85a IEEE Standards for Local Area Networks: Carrier Sense Multiple Access with Collision Detection (CSMA-CD) Access Method and Physical Layer Specification.

IE85b IEEE Standards for Local Area Networks: Token-Passing Bus Access Method and Physical Layer Specification.

IE85c IEEE Standards for Local Area Networks: Token Ring Access Method and Physical Layer Specification.

IN90 INMOS Limited - Transputer Development System - Second Edition, Prentice Hall, Reino Unido, 1990

KA91 The Ka9Q Internet Software Package, 1991

KI89 KIRNER, C. Sistemas Operacionais para Ambientes Paralelos. In: Congresso SBC, 9., Uberlândia - 16 a 21 de Julho, 1989.

LE81 LELANN, G. Motivations, Objectives and Characterization of Distributed Systems in Lampson et al, 1981.

MU89 MULLENDER, S. Distributed Systems ACM Press Addison - Wesley Publishing Company; 1989.

PA88 PAGE-JONES, M. Projeto Estruturado de Sistemas São Paulo, MacGraw Hill, 1988.

PA93a PALMA Jr., O.; Manual de Utilização do Servidor de Processamento Paralelo (SPP). São Carlos - SP, 1993. (Relatório Fapesp)

PA93b PALMA Jr., O.; Documentação do Software do CM/SPP - bt.tsr. São Carlos - SP, 1993. (Relatório Fapesp)

PO81 POPEK, G.; WALKER, B.; CHOW, J.; EDWARDS, D.; KLINE, C.; RUDISON, G.; THIEL, G. LOCUS: a Network Transparent, High Reliability Distributed System. Proceedings of the Eighth SOSP, Pacific Grove, California. 
R085 ROBERTS, W.T. A Comparison of Two Remote Procedure Call Mechanisms Computer Science Report, Queen Mary College, London, 1985

SA90

SANTANA, R.H.C; SANTANA, M.J.; ZALUSKA, E. TRICE - a Transparent Multi-LAN Distributed Computing System Anais da XVI Conferência Latino Americana de Informática, 10 a 14 de Setembro, 1990, Paraguai.

SC82 SCHROEDER, M.; BIRREL, A.D.; LEVIN, R.; NEEDHAM, R.M. Grapevine: An Exercise in Distributed Computing, Communications of the ACM, Vol. 25, Abril, 1982.

SC84 SCHOROEDER, M.; BIRREL, A.D.; LEVIN, R.; NEEDHAM, R.M. Experience with Grapevine: the Growth of a Distributed System, ACM Transactions on Computer Systems, Vol 2, no.1, Fevereiro, 1984.

SI92

SINHA, A. Client-Server Computing, Communications of the ACM, Vol. 35, n. 7, Julho, 1992.

SP82 SPECTOR, A.Z. Performing Remote Operations Efficiently on a Local Computer Network, Communications of the ACM, Vol.25, n. 4, Abril,1982.

ST84

STALLINGS, W. Local Networks Computing Surveys, Vol.16, n.1, Março 1984.

TA85 TANENBAUM, A. S.; van RENESSE, R. Distributed Operating Systems Computing Surveys, Vol. 17, n. 4, 1985.

TA86 TAROUCO, L. M. R. Redes de Computadores: Locais e de Longa Distância, McGraw-Hill, São Paulo, 1986.

TA89 TANENBAUM, A. S. Computer Networks Prentice-Hall, NJ, 1989.

TA90 TANENBAUM, A. S.; van RENESSE, R.; van STAVEREN, H.; SHARP, G.J.; MULLENDER, S.J.; van ROSSUM, G. Experiences with the AMOEBA Distributed Operating System Communications of the ACM, Vol. 33, n. 12, Dezembro, 1990.

TA92 TANENBAUM, A. S. Modern Operating Systems Prentice-Hall, 1992. 
TR91 TRINDADE Jr, O.; SANTANA, M.J. Um servidor de Processamento Paralelo Baseado em Transputers tese apresentada junto ao Instituto de Física e Química da USP de São Carlos, em Dezembro de 1991.

UL93 ULLMAN; E. Client / Server Frees Data - Byte, Junho, 1993.

WE89 WEXLER, J. Concurrent Programming in Occam2 Ellis Horwood, 1989.

WI80 WILKES, M. V.; NEEDHAM, R. M. The Cambridge Model Distributed System, ACM Operating Systems Review, Vol. 14, n. 1, Janeiro, 1980.

WI87 WILBUR, S. Building Distributed Systems with Remote Procedure Call, Software Engineering Journal, Setembro, 1987.

ZI80 ZIMMERMANN, H. OSI Reference Model - The ISO Model of Architecture for Open System Interconnection, IEEE Transactions on Communications, Vol.28, n.4, Abril, 1980. 


\section{Apêndice A}

\section{Instalação e Utilização dos Sistemas}

Neste apêndice são descritos os passos necessários para a instalação e a utilização do sistema SPP tanto na versão original, quanto na versão TCP/IP.

\section{A.1 Sistema SPP - Ambiente Original}

O Sistema de Desenvolvimento TDS é constituído de duas partes, uma delas executada no computador hospedeiro, o "iserver", e a principal, o TDS, executada no processador raiz de uma rede de Transputers. $O$ "iserver" possibilita 0 carregamento de programas objetos no processador raiz da rede, permanecendo ativo, atendendo requisições de serviços relativos a arquivos, vídeo e teclado, provenientes do TDS ou de um programa do usuário.

$\mathrm{O}$ "iserver" teve a sua estrutura ligeiramente alterada para a operação com o SPP [AN91,AN93]. Uma vez que o sistema opera através de uma rede local, toda comunicação entre o TDS ou programa do usuário com a Estação de Trabalho (ET) é feita através da rede. As alterações realizadas no "iserver" concentraram-se nos módulos de comunicação, os quais passaram a receber e enviar os pacotes SP através da rede para o servidor.

Os procedimentos necessários para a configuração do ambiente de utilização do Servidor de Processamento Paralelo, com o Sistema de Desenvolvimento TDS, foram descritos no capítulo 5. Qualquer usuário com acesso a uma ET do sistema pode executar o TDS com o auxílio dos recursos computacionais do Banco de Transputers, desde que esses recursos estejam disponíveis. A seguir são descritas as primitivas disponíveis no sistema: 


\section{- Abrir uma sessão}

Abrir uma sessão no sistema consiste em se identificar perante o sistema, fornecendo um nome identificador. $\mathrm{Na}$ atual implementação, não é verificado nenhum tipo de senha de proteção, de forma que qualquer pessoa pode ter acesso ao sistema desde que use um nome cadastrado no arquivo de login.

Para se abrir uma sessão, na ET devidamente configurada e preparada para trabalhar como estação do SPP, execute o utilitário login, digitando

login <user>

na linha de comando do sistema operacional.

O sistema irá responder com um pedido de identificação, caso não tenha sido passado na linha de comando.

O utilitário login executado na $\mathrm{ET}$, nada mais é do que um comando remoto executado no Processador de Entrada (PE) através de uma chamada RPC ao servidor. No servidor (PE), fica reservado um identificador de sessão que será usado para todas as próximas operações do usuário.

\section{- Alocar os processadores}

Os recursos computacionais paralelos (placas de Transputers) são compartilhados entre até quatro usuários, segundo a implementação atual. Portanto, cada usuário deve reservar os recursos necessários para a sua sessão de trabalho. Para isso, deve executar o utilitário lot na linha de comando da estação:

lot

O sistema irá solicitar o número de processadores que serão alocados ao usuário:

Nro.de procs:

Esse utilitário faz uma chamada remota ao SPP, sendo que a alocação é feita pelo Controlador de Módulo, uma vez que, quando a chamada chega ao PE, ela é roteada para o Controlador de Módulo do Banco. 
Caso não haja um número de processadores suficientes, uma mensagem de "Erro na alocação dos procs." aparece. Outras mensagens são geradas quando ocorre algum problema de comunicação com o servidor.

Como resultado da alocação do lote, é apresentado na estação a seguinte mensagem:

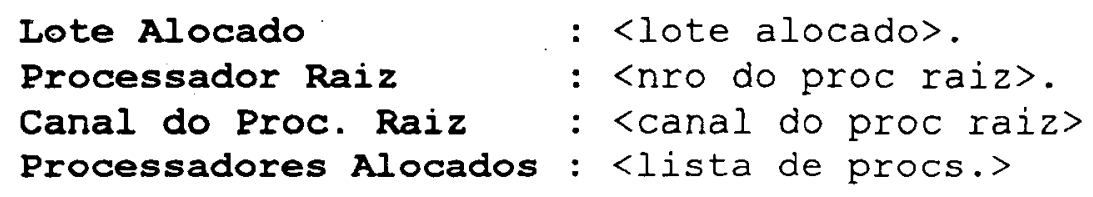

Um exemplo dessa mensagem para um usuário que solicite 3 processadores

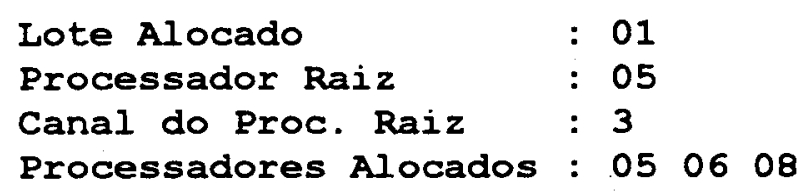

Após a alocação dos processadores por parte de um usuário, o sistema tem a configuração física apresentada na figura A.1.

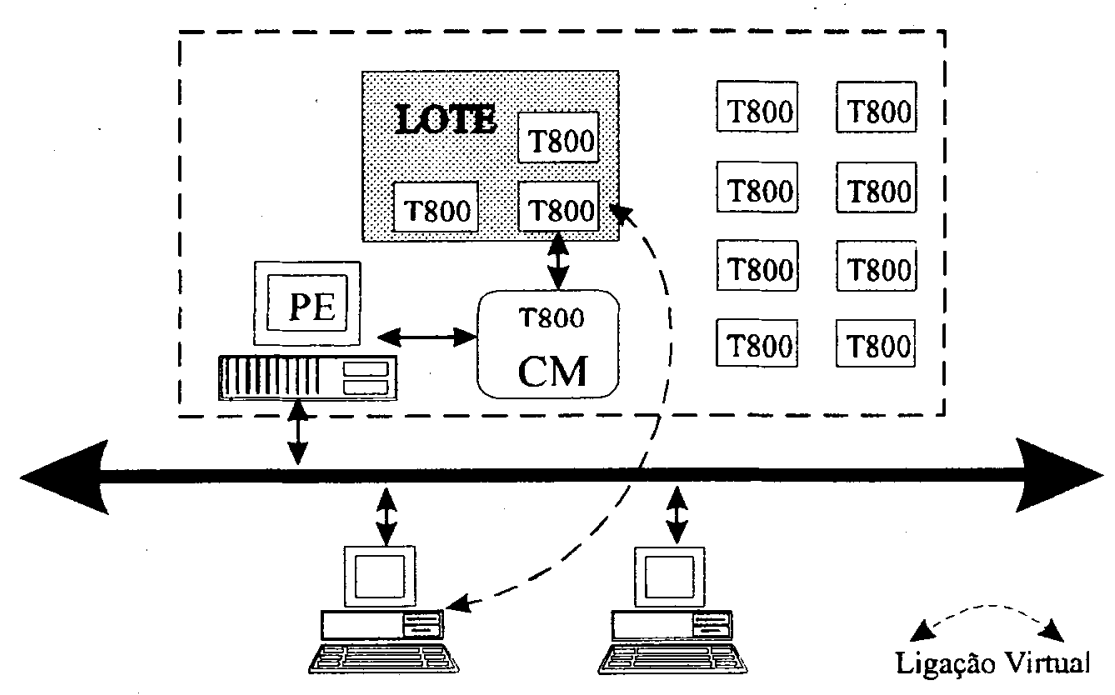

Fig. A.1 - SPP após a alocação de 3 Procs.

Pode ser observado na Figura A.1 que um dos processadores do lote (processador raiz) é conectado virtualmente à ET e não há ligação nenhuma entre os Processadores alocados. 
Os processadores alocados são reservados ao usuário até que ele execute o utilitário dlot, para liberar os processadores.

\section{- Executar o programa TDS}

A execução do TDS normalmente é inicializada através do comando TDS3 digitado na linha de comando do computador hospedeiro. TDS3 é um arquivo em lote, contendo comandos que têm acesso ao programa "iserver", encarregado de controlar a comunicação hospedeiro/Transputer. O "iserver" carrega o TDS no processador raiz e passa a controlar disco, teclado e vídeo na estação.

No caso do SPP, o programa "iserver" foi modificado e passou a chamar iserverb. Com isso, o arquivo TDS3.BAT também foi alterado, passando a denominar-se TDSB.BAT, portanto, para a execução do TDS em uma ET, após os procedimentos de abertura de sessão e alocação de processadores, basta o usuário digitar:

tdsb

Daí para frente tudo passa a ser transparente para o usuário, isto é, aparentemente o usuário tem uma placa de Transputer ligada diretamente à sua ET, como na figura A.2.

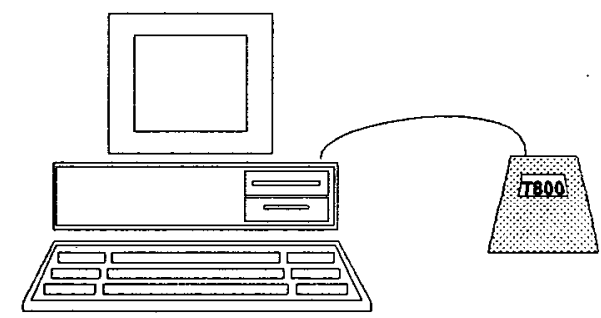

Fig. A.2 - ET ligada diretamente ao processador Transputer

\section{- Liberar os processadores}

Quando uma sessão de trabalho é terminada, o usuário deve liberar os processadores para que fiquem disponíveis a outros usuários. Isso é feito de forma simples através do utilitário dlot. 
O comando dlot libera o lote de transputers reservado ao usuário e desfaz a ligação virtual entre a estação e o processador raiz, voltando o sistema à configuração original.

\section{- Liberar a sessão}

O processo de liberar o lote de Transputers, apenas libera os processadores para que possam ser usados por um usuário em outra ET. A sessão iniciada é mantida. Isso significa que um usuário pode abrir uma sessão, alocar um lote com 1 processador para a execução do TDS, liberar esse lote e. alocar outro com vários processadores para executar um programa em uma rede, tudo em uma mesma sessão de trabalho. Como o sistema possui um limite máximo de 4 sessões, caso as quatro estejam sendo utilizadas, nenhum novo usuário poderá ter acesso ao sistema. Portanto, quando uma sessão de trabalho é terminada e o usuário não mais usará os recursos do SPP, a sessão obtida com o utilitário "login" deve ser liberada. Nesse caso deve ser usado o utilitário "logout" como abaixo:

logout

A execução desse utilitário libera a sessão, pemitindo que um novo usuário possa ter acesso ao sistema.

\section{A.2 Sistema SPP - Ambiente TCP/IP}

Para um bom funcionamento do sistema net, modificado para spp.exe, os arquivos de configuração, descritos no capítulo 6, devem estar instalados no diretório raiz, para evitar que se especifique o caminho na linha de comando. Depois copia-se o programa spp.exe no diretório desejado para a utilização.

Para utilizar o sistema deve-se digitar na linha de comando

spp

e a partir desse ponto já estará sob execução na shell do ambiente TCP/IP.

Conforme descrito no capítulo 6, o sistema SPP ficou disponível como um comando fornecido pelo net original. Assim para abrir uma sessão para comunicação com o Banco de Transputers deve-se digitar, na shell sistema do spp, o comando:

net> spp boitata 
ou também

net> spp 143.107.231.69

que é o endereço IP da máquina servidora. Assim o sistema já solicitará o nome do usuário seguido da sua senha, que devem estar cadastrados no arquivos FTPUSERS da máquina servidor, corforme descrito no capitulo 6.

\section{- Alocar os processadores}

Para se alocar um lote de transputers no banco deve-se digitar o comando:

spp>lot <nro_processadores>

Caso não haja um número de processadores suficientes, uma mensagem de "Erro na alocação dos procs." aparece. Outras mensagens são geradas quando ocorre algum problema de comunicação com o servidor.

Como resultado da alocação do lote, é apresentado na estação uma mensagem informando quantos transputers foram alocados e a seguinte mensagem aparece na tela do servidor:

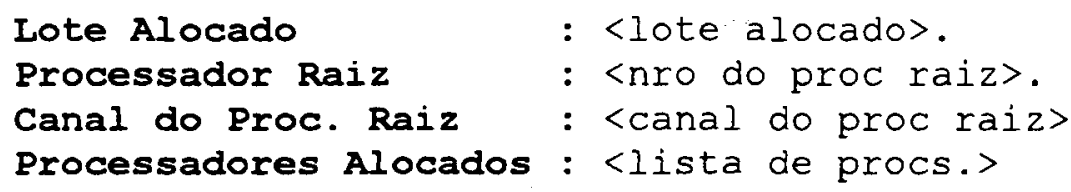

\section{- Executar um programa "standalone" no Banco de Transputers}

Para se executar um programa (previamente transferido para a máquina servidora) "standalone" no banco de transputers deve-se digitar o comando iserv que executa o programa e grava o resultado em um arquivo.

spp>iserv

\section{- Liberar os processadores}

Para se liberar um lote de transputers no banco deve-se digitar o comando: spp $>$ dlot

que informa se o lote foi liberado com sucesso. 
- Liberar a sessão

Para se liberar a sessão deve-se digitar o seguinte comando:

spp> quit

Com esse comando volta-se para a shell do sistema net e para voltar ao DOS, deve-se digitar:

net> exit

Finalizando assim a operação do sistema. 